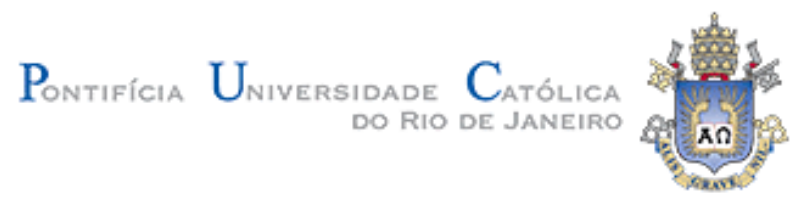

Tiago Oliveira de Castro

\title{
Zoneamento Socioambiental de Restrições Legais a Obras de Infraestrutura: Estudo de caso da \\ ferrovia EF-118, Nova Iguaçu (RJ) - Cariacica (ES)
}

\section{Dissertação de Mestrado}

Dissertação apresentada ao Departamento de Engenharia Civil da Pontifícia Universidade Católica do Rio de Janeiro como requisito parcial para obtenção do título de Mestre em Engenharia Urbana e Ambiental.

Orientador: Prof. Luiz Felipe Guanaes do Rego

Rio de Janeiro

Dezembro de 2014 


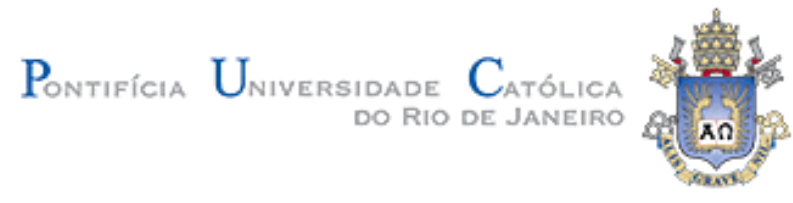

Tiago Oliveira de Castro

\section{Zoneamento Socioambiental de Restrições Legais a Obras de Infraestrutura: Estudo de caso da ferrovia EF-118, Nova Iguaçu (RJ) - Cariacica (ES)}

Dissertação apresentada como requisito parcial para obtenção do título de Mestre em Engenharia Urbana e Ambiental (opção profissional) pelo Programa de Pós-Graduação em Engenharia Urbana e Ambiental da PUC-Rio. Aprovada pela Comissão Examinadora abaixo assinada.

Prof. Luiz Felipe Guanaes Rego Presidente / Orientador Departamento de Geografia - PUC-Rio

Prof. Ricardo Abranches Felix Cardoso Júnior UFF

Profa. Ana Paula Dias Turetta EMBRAPA

Prof. José Eugenio Leal Coordenador Setorial de Pós-Graduação do Centro Técnico Científico - PUC-Rio

Rio de Janeiro, 18 de dezembro de 2014. 
Todos os direitos reservados. É proibida a reprodução total ou parcial do trabalho sem autorização da universidade, do autor e do orientador.

\section{Tiago Oliveira de Castro}

Graduou-se em Geografia na Universidade Estadual do Rio de Janeiro (UERJ) em 2008, obteve título de pós-graduação em Gestão Ambiental no Instituto Alberto Luiz Coimbra de Pós-Graduação e Pesquisa de Engenharia (COPPE) da Universidade Federal do Rio de Janeiro (UFRJ) em 2009. Atualmente atua como consultor técnico de meio ambiente para a Petrobras, tendo atuado também para empresas do setor energético, além de empresas do setor de logística na área de Meio Ambiente, com os temas geoprocessamento e ambiental.

Ficha Catalográfica

Castro, Tiago Oliveira de

Zoneamento socioambiental de

restrições legais a obras de infraestrutura: estudo de caso da ferrovia EF-118, Nova Iguaçu

(RJ) - Cariacica (ES) / Tiago Oliveira de Castro ; orientador: Luiz Felipe Guanaes Rego. - 2014.

141 f. : il. (color.) ; $30 \mathrm{~cm}$

Dissertação (mestrado)-Pontifícia

Universidade Católica do Rio de Janeiro,

Departamento de Engenharia Civil, Programa

de Pós-Graduação em Engenharia Urbana e Ambiental, 2014.

Inclui bibliografia

CDD: 624 
À minha Flavinha.

Aos meus pais e familiares.

Aos meus caros amigos. 


\section{Agradecimentos}

Ao meu orientador Professor Luiz Felipe Guanaes do Rego pelo estímulo e parceria para a realização deste trabalho.

A equipe do Departamento de Engenharia Civil e professores durante todo o curso, especialmente na etapa de defesa da dissertação.

Aos amigos Portela e Politano pelo apoio e ajuda sempre que tive dúvidas.

Aos amigos da PUC-Rio, em especial ao Felipe Mazur.

Aos colegas de trabalho pela paciência e compreensão.

Aos professores que participaram da Comissão Examinadora. 


\section{Resumo}

Castro, Tiago Oliveira de. Rego, Luiz Felipe Guanaes. Zoneamento Socioambiental de Restrições Legais a Obras de Infraestrutura Através do uso de Geotecnologias - Estudo de caso da ferrovia EF-118, Nova Iguaçu (RJ) - Cariacica (ES). Rio de Janeiro, 2014. 141p. Dissertação de Mestrado - Departamento de Engenharia Civil, Pontifícia Universidade Católica do Rio de Janeiro.

A questão ambiental é hoje um tema de extrema relevancia em todo o mundo e no Brasil, reconhecidamente um país biodiverso não poderia deixar de ser diferente. Aliado a esse fator ambiental, vivemos um ciclo de expansão econômica, em que os setores produtivos vem se apropriando de espaços e abrindo novas fronteiras de atuação. Dessa forma, o planejamento ambiental é uma importante ferramenta, tanto no auxílio à administração pública da gestão territorial, quanto para o empreendedor em sua atuação. Do planejamento ambiental, pode-se alcançar o zoneamento ambiental, que estabelece áreas ou zonas de características homogêneas, orientando a escolha de parcelas do território mais ou menos propícias a diferentes atividades desempenhadas pela sociedade. O objetivo principal do estudo foi a análise de modelos para o zoneamento de restrições socioambientais legais, através do estudo de caso do traçado de ferrovia que ligará a cidade de Nova Iguaçu, no Rio de Janeiro à cidade de Cariacica, no Espírito Santo. Como objetivos secundários estão presentes a análise da legislação pertinente, a identificação de determinados componentes socioambientais legais da área de estudo, além da comparação entre diferentes modelos de mapeamento. Como resultado, foram elaborados mapas, utilizando diferentes modelagens para o zoneamento de restrições legais. Um dos mapas gerado se mostrou o mais adequado e subsidiou a escolha de um novo traçado de ferrovia, atravessando áreas com menores restrições socioambientais legais.

\section{Palavras-chave}

Geoprocessamento; Planejamento Ambiental; Zoneamento Ambiental. 


\section{Extended Abstract}

Castro, Tiago Oliveira de. Rego, Luiz Felipe Guanaes (Advisor). Environmental Zoning of Legal Restrictions for Infrastructure Works Through the use of Geotechnologies - the railroad EF-118 Nova Iguaçu (RJ) - Cariacica (ES) study case. Rio de Janeiro, 2014. 141p. MSc. Dissertation - Departamento de Engenharia Civil, Pontifícia Universidade Católica do Rio de Janeiro.

The main objective of this work was to evaluate the zoning methodology of the legal socio environmental restrictions towards the soil use and occupation, using geoprocessing tools to subsidize the choice of the railroads tracings, through the case study of the EF-118 via, Nova Iguaçu (RJ) - Cariacica (ES).

Among the specific objectives are: analize the concepts of geotechniques and the application of spacial analysis tools as support to the land management, figuring out the planning and environmental zoning, identify and analyze the legal socioenvironmental spatial data related to the theme and analysis models of data to environmental zoning from the case study of the railroad Nova Iguaçu (RJ) Cariacica (ES), for identification of legal socio environmental restrictions to the railroad tracing.

In general, the research takes place in the Brazilian context, where the country sees itself as the 7th world's largest economy; the 8th world's largest consumer market, still being world's natural resources supplier - standing out Iron and eucalyptus pulp.

In this scenario, the transportation network expansion is fundamental; however, currently the Brazilian transportation system finds itself before two paths. On one side a strong modernization movement in the companies, which demand increasingly efficient, trustable and sophisticated logistic services, in order to keep competitive in a world that has globalized, and where logistic is, more and more determinant to business success. On the other side, a set of structural problems, that distort the Brazilian transport matrix and contribute to the quality services commitment, the operators financial health and mainly the country's socio economic development. (Wanke e Fleury, 2006) 
In 2011, the transport matrix was divided in: road, with 59\% of participation; railroad, with $24 \%$ of participation; water, with $13 \%$ of participation; air with $0,3 \%$ of participation and pipeline, with $3,7 \%$ of participation.

The railways represent today one alternative to face the Brazilian transportation logistical grip, principally due to its advantages over the other models, being ideal to large volumes of cargo, besides being the most indicated to long distances and to low value-added products - Commodities - transportation.

This way, the current study was motivated by the railroad network that should expand in a scenario where the environmental issues are becoming increasingly important. Consequently, it is necessary a better understanding of the territory and the risks associated to its use.

As a way to reach this understanding, the spatial analysis tools are essential for the planning of the land use to be aligned with the legal basis of environmental conservation and preservation, subsidizing the elaboration of the environmental zoning, which allows the establishment of areas reasonably favorable to the development of economic activities. All these activities are intended, among others, to open room for the entrepreneur to be able to visualize more adequate locational alternatives, avoiding future complications in the environmental licensing.

Such tools rely on theoretical and methodological references, which base the construction of new perspectives and interpretations of the region from public socio and environmental spatial data, being used as input. This new interpretation of the territory was built with the help of four main themes. They are: the Brazilian Environmental Legislation, the Environmental Planning, the Environmental Zoning and the Geotechnologies.

This way, the starting point for the goal to be achieved in this current study was the analysis of the Brazilian environmental legislation, which holds social aspects, physical environment aspects and biotic aspects. The legislation guided 
the spatial socio-environmental data collection in order to map the main use restrictions and land occupation provided by law. Through literature search, the Brazilian environmental legislation was collected, for identification of the potential restrictions and limitations of land use and occupation and for construction projects.

In relation to the Brazilian Environmental Legislation, considered one of the most advanced in the world, are highlighted, in this research, those which are about topics related to the aims that are to be reached, that is, the ones which have objectively straight relationship with the land management and which, consequently, can be represented in the space.

Such legislation is the result of an accumulation of other experiences related to the regulation and orientation towards conservation and preservation of the environment. Among these experiences stands the "National Environmental Policy Act (NEPA)", North-American regulation of 1969, which instituted the Environmental Impact Assessment/EIS, whose efficiency echoed, among other aspects, in the effectiveness of the civil society participation in the decision process towards the environmental viability of the projects. Also, by influence of the Stockholm Conference, the repercussions from this same Conference soon sounded, and, already in the 70s, large-scale projects, under the screen of multilateral funding agencies, were submitted to the Environmental Impact Assessment, as the case of the hydroelectric power plant of Sobradinho, first enterprise to undergo environmental evaluation in Brazil, in the year of 1972.

The experiences in environmental impact assessment followed up in the 70s, culminating in the consecration of that regulation as a tool of the National Environmental Policy, Law $N^{\circ}$ 6938/81, in association with the licensing of the activities using environmental resources considered effective or potentially polluting. Besides this law; Law No 9605/98, which deals with Environmental Crimes, Law 9.985/2000, which instituted the National Protected Units System; Law 12.651/2012, which establishes the Forest Code; the Resolutions CONAMA 001 and 237, which orient the Environmental Licensing of potentially environmental modifying activities and the Ministerial Decree $\mathrm{N}^{\circ} 419$, which 
regulates the performance of organs and entities of the Federal Government involved in the Environmental Licensing, such as FUNAI and Palmares Foundation, were considered to the analysis elaboration performed to reach the intended goal of this research.

Other concepts that underpinned this research now developed were those related to the Environmental Planning, presented by authors like CONYERS and HILLS (1984), BARRETO (2000), OREA (1994), VAN LIER (1994), VAN DE LAAK (1994), DORNEY (1989), CHRISTOFOLETTI (1999), PARTIDÁRIO (1999), among others, as a way to understand the elaborating planning process of the land use in a broader way.

Seeking the concepts of environmental planning for answers for the intended goal, it is noticeable that such concept is increasingly inserted in a broader planning context, which is the one of land use and occupation, not only in Brazil, but in the world. This way, the environmental issues are always associated to the territory management and need to be considered in the decision taking by the actors responsible for the public as well as the private space managing.

Accordingly, having in mind the Environmental Planning as environment integrated analysis, the planner should never forget that the most important parts involved in this process are the society, nature and the dynamics of mutual influence in the interaction between both of them. Society, using an ecosystem, whatever ecosystem, modifies its structure and functioning, causing impacts that can be irreversible. However, this can be avoided or minimized through the previous knowledge and planning of the use of the ecosystem. The planning should be able to produce and define norms of land use and occupation and to establish clear guidelines for sustainable development and conservation of the environment, suggesting alternatives to reverse the process of social and economic environmental deterioration.

This way, the planning is a continuous process that involves decisions or choices about the available resources with the objective of reaching specific goals somewhere in the future (CONYERS and HILLS, 1984), helping the decision 
taking or choice, involving the various alternate ways, and which the best one is to reach those same goals, with the aim of establishing uses or allocation of resources, which can be natural, human, financial or infrastructural.

Consequently, the planning can establish alternate ways to reach the outlined objectives, involving realistic goals, political decisions and popular participation. This way, the Planning is made up focused in the future, which involves forecasts or approximate predictions of what can happen and, more specifically, predicting outcomes of the alternative proposals, which determines the ones to be adopted.

In short, the Environmental Planning is the integrated analysis of the environment, taking into account the society, nature and the dynamics of mutual influence between both of them and should be capable of producing and defining norms of the land use and occupation, besides establishing clear guidelines for the sustainable development and conservation of the environment.

Therefore, in brief, the environmental planning seeks to establish the society acting limits in its relationship with the environment. So, it makes sense the effort in understanding the territory in which it is intended to act, projecting the actions that will be developed in the space, to forecast which the consequences of the human interventions are over the natural resources available and this was the reasoning line taken in the research exposed here.

To achieve the Environmental Planning, the tool of the Environmental Zoning is taken as a way to diagnose the territory in relation to its limits and skills. It is, therefore, a multidisciplinary research balanced, quantitative, to be developed with analytical and systemic focus, orienting the review and/or elaboration of research policies and conservation and integrated handling of natural resources.

To ROSS (2006), the environmental zoning is an integrating process of technical-scientific disciplines, since he considers the environmental potencialities, seeking to establish a harmonious relationship between society and 
nature, based on the spatial planning and on the development linked to the conservation policy.

DEL PRETTE and MATTEO (2006) briefly define the term zoning describing it as an action tool used by private agents and by the government since the constitution of the societies, with the aim of distributing the human activities around the phsical space in an organized way.

The Environmental Zoning came up representing what would be a third line of thought, presenting normative feature, restricted and having as a goal to protect the environment (Millikan and Del Prette, 2000).

Silva and Santos (2004) argue that the zonings under various features that they might receive, converge in their results, which is the delimitation of areas, even though different methodological guidelines, varying according to the objective or to the object.

Therefore, the zoning cannot be seen only as a restriction tool, but as a social regulating one of the social use of the natural resources. So, it must be seen as a land management model, based on the availability and transparency of information and on the social negotiation of the regulating goals of the appropriation and use of the territory.

At this point, one can make use of tools of geotechnologies for the execution of the Environmental Zoning. The geotechnologies take a relevant role in the environmental management for turning the managing of spatial data more didatic and intuitive, besides allowing different types of analysis, raising the critical power in the decision taking. They can be understood as one technology that integrates data contained in a plan of spatial data or georeferenced.

Its treatment and manipulation open a range to the elaboration of theme maps analysis somewhat simple, which establish correlations between the spatial representation and the available information. 
Inserted in this context are the Geographic Information Systems - GIS, which, for RODRIGUES (1993), can be understood as a "collection set of technologies, processing, handling and presentation of spatial information”. Allied to GIS, is the GIS Data Base, which consists of a data collection interrelated and a program to provide the access to these data, according to MAZUR (2013). The correlation between the GIS and its Geographical Data Base can be understood as the Spatial Analysis in GIS, tool that allows various types of manipulation of spatial data in order to extract new knowledge as products.

After the conceptualization, it is worth to present the case study, since the developed research was motivated by a project demand for the establishing of a new railroad trace. The railroad Nova Iguaçu/RJ - Cariacica/ES, whose trace will be evaluated and possibly reconfigured for the its reactivation, is approximately $640 \mathrm{~km}$ long in an predominantly northeast - southwest alignment, and develops transposing the portion central-south of the state of Espírito Santo and the state of Rio de Janeiro, from the border to the north with the state of Espírito Santo, up to its central-south, ending in the "baixada fluminense" region, near the capital of the state of Rio de Janeiro.

For the development of the socio environmental zoning, which is the main goal of this research, was used as input public data basis namely: natural cavities, speleological potential, conservation units, priority areas for the biodiversity conservation, quilombo communities, indigenous lands and use and ground cover, this last one for identification of the Mata Atlântica remaining and definition of areas with anthropic use.

For the use of data and its insertion in a database, it was necessary the performing of pre-processing. They were: alteration of the DATUM and of the coordinate system developed, to standardization, avoiding positioning mistakes. It was also executed a data selection contained in the spatial area established for the developing of the research - states of Rio de Janeiro and Espírito Santo, in order to reduce the storage space, improving, at the same time the further processing, for the mass of worked data gets smaller. Besides, it was established the buffer zones of the Conservation Units ( $3 \mathrm{~km})$, Indigenous Lands $(5 \mathrm{~km})$ and Quilombo 
Communities $(5 \mathrm{~km})$ as instructed on Legislation. At last, it was attributed values to the socio environmental aspects identified in the official public basis divided in a scale of 1 to 5 , based on the current environmental regulations, where 1 means lower risk aspects both to the environment and the enterprise, thus not needing trace deviation and 5 that means aspects of higher risk both to the environment and enterprise, thus needing trace deviation.

The data worked were this way classified: Unnecessary - No relevant socio environmental aspect was identified in the data used; Negotiable - Conservation Units of sustainable use, Quilombo Community Buffer Zones and Indigenous Lands; Unnecessary - with mapped aspects - Buffer Zone of Conservation Units of sustainable use and Priority Areas for the Biodiversity Conservation; Preferential - High occurrence potential of natural cavities and Mata Atlântica areas; Necessary - Conservation Units of full protection and Natural Cavities.

At first, the research was thought in the logic of the represented scene through maps and, in each scene, some weight variations were established, in order to make a comparison among them possible. Besides the differences in weights for their composition, three of the scenes were based on vector data and five of the scenes based on raster data. This differentiation also occurred so that there was a possibility of comparison of results among the formats of the input data models, in addition to the already mentioned weights.

For vector data the models were "Sum Models - Equal Intervals", where the values were classified in equal intervals. The classifying through equal intervals divides the extension of values from the attributes in equalized subclasses. This allows the specification of the number of intervals, which, in this case, was of 5 intervals and so it is determined one break for each of them, based on the total extension of the attribute values.

Still, for the data in format vector, it was done the "Sum Model - classified in natural breaks", in which, through an algorithm (Jenks algorithm), groupings are made naturally established among the values present in the attributes of the spatial data. The class breaks are defined by the best similarity in the composition 
of a grouping for similar values and stress of differences among classes. The layers are divided in classes in which limits are established where there is a large relative difference in the data values.

The last model generated from the vector data, called "Weighted Model with weight equitable attribution", is the result of the attribution of weights to the values pre-established to each of the legal environmental restrictions used to composse the intended zoning. In the case study, were attributed the same weights to each of the variables or legal socio environmental restrictions.

As for the raster data, five maps were elaborated, through the application of two models: "Weighted Sum", which after weight classification and attribution resulted in two maps with adoption of matrix 1 to 5 to 1 , more suitable to the case in question, due to this same case present five classes of restrictions. Therefore, as application product of the methodologies cited, it can be appreciated 5 different maps, having as subsidy for its elaboration the same input data of all the others.

The first scene for raster data was "Weight Sum Model - with weights equitable attribution", was attributed weight 1 to all the legal socio environmental restrictions identified. This way, each of these restrictions was multiplied by the established weight, added and overlapped.

The second scene for raster data was the "Weighted Sum Model - with attribution of different weights to legal socio environmental restrictions" in which were attributed different weights in order to highlight some restrictions that, by experience, are more complex and require greater effort to be beaten, when there is possibility of negotiation.

The third scene, using as input raster data was "Weighted Average Model with weight equitable attribution and adoption of restricted areas to pixels valued 5", in which, for the execution of processing models in raster data is possible, differently from what happens with vector data, establish restricted areas, which independently from weights and values are not computed in the weighing. This is especially advantageous when it is known in advance that some aspects that 
composse the spatial analysis are clear and objectively restricted, making rule the exclusion of these aspects in the weighted average equation.

The fourth scene elaborated from the raster data was "Weighted Average Model - with weight equitable attribution and adoption of restricted areas to pixels value 5, except the ones of the category Urban Areas/ Anthropic Areas", which is based on the same assumptions of the previous model, where the rule for pixels valued 5 is of restriction. The difference here is due to the exception to those categorized as Urban Areas/Anthropic Areas, considered so in the weighing as with the other categories and their respective values.

Lastly, the scene "Weight Average Model - with different weight attribution for legal socio environmental restrictions and adoption of restricted areas to pixels valued 5, except the one of the category Urban Areas/ Anthropic Areas", which is a little more complex than the others cited so far, because more than establishing restricted areas, excluding from such rule the Urban Areas/Anthropic Areas, still establishes different weights to each socio environmental aspect considered.

After the appreciation of the model result, it seems that in considering a more complexity in its construction, the zoning becomes quite limiting for the action in terms of the land use and occupation, pointing to the necessity for further adjustments in the weighting.

Henceforth, for the Study of Technical, Economic and Environmental Viability of the railroad tracing, it was defined as the most adequate model, so, the "Weighted Average with weight equitable attribution and adoption of restricted areas to pixels valued 5, except the ones of the category Urban Areas/ Anthropic Areas". This model was reffered to a group of engineering designers, which in turn, performed adjustments to the projected tracing at first, without having taken into account the legal socio environmental variable of restriction of land use.

For purposes of comparison, the original tracing existing today, has an approximate length of $640 \mathrm{~km}$, yet the proposed tracing considering only the engineering criteria is approximately $620 \mathrm{~km}$ long and, finally, the proposed 
tracing after the applying the defined model as the most adequate is approximately $670 \mathrm{~km}$ long.

The tracing, considering the legal socio environmental restrictions is, this way, the longest. However it is the one which presents the smallest chance of finding some limitation to the project. This way, the entrepreneur is able to assess which will be more advantageous for the intended work.

\section{Keywords}

GIS; Environmental Planning; Environmental Zoning. 


\section{Sumário}

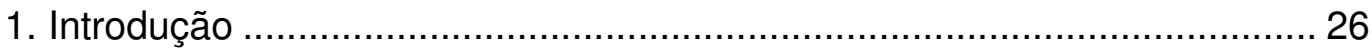

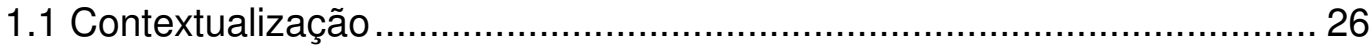

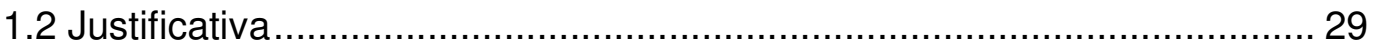

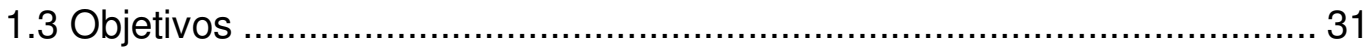

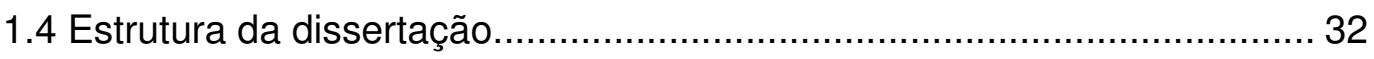

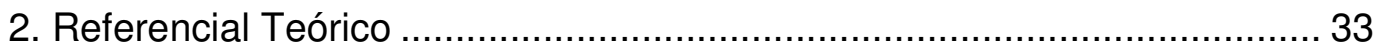

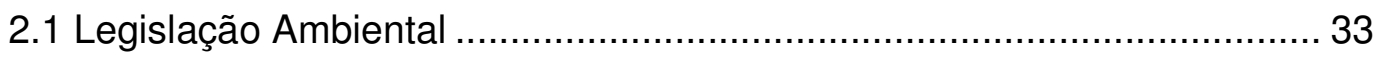

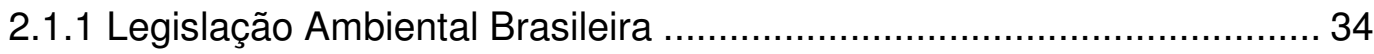

2.1.2 Licenciamento Ambiental ............................................................... 39

2.2. Planejamento Ambiental....................................................................... 42

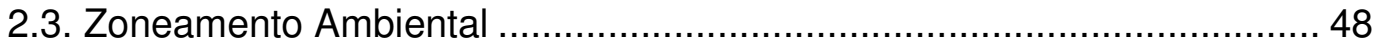

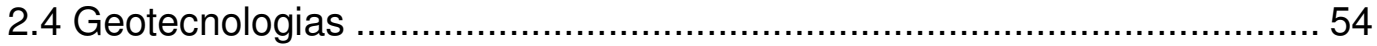

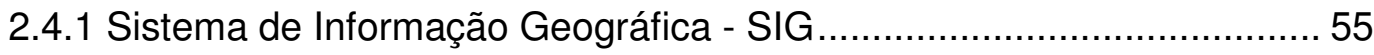

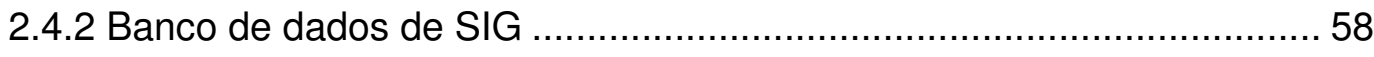

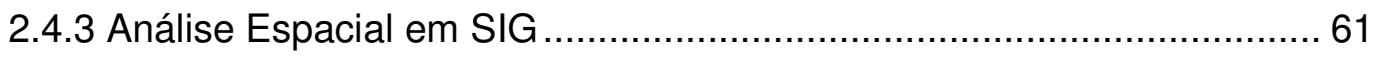

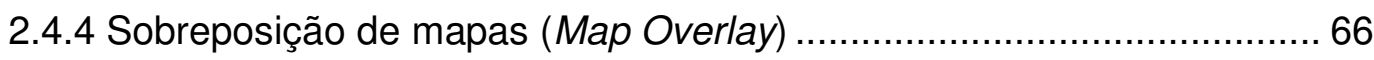

3. Estudo de caso - Viabilidade Socioambiental Legal para o traçado da linha ferroviária Nova Iguaçu (RJ) - Cariacica (ES) .................................... 71

3.1 Recorte espacial............................................................................. 71

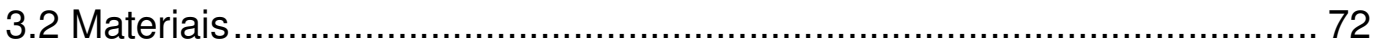

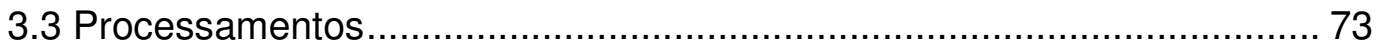

3.3.1 Pré-processamentos aplicados aos dados socioambientais legais oriundos de bases públicas em formato vetorial ............................................ 74

3.3.2 Processamento de dados em formato vetorial .................................... 81

3.3.3 Processamento de dados em formato raster....................................... 96

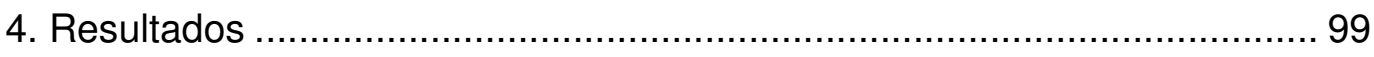

4.1 Análise de dados socioambientais legais ............................................... 99

4.1.1 Cavidades Naturais e Potencial Espeleológico ................................. 100 
4.1.2 Unidades de Conservação - SNUC ................................................... 101

4.1.3 Comunidades Quilombolas ......................................................... 102

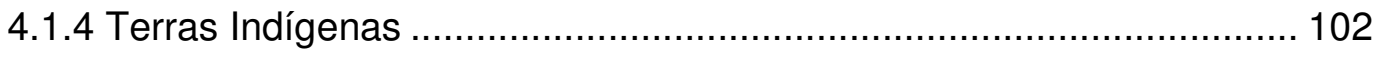

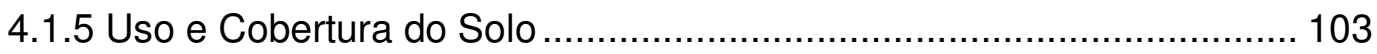

4.1.6 Áreas Prioritárias Para Conservação da Biodiversidade ..................... 107

4.2 Zoneamento Ambiental de Restrições Socioambientais Legais - Dados

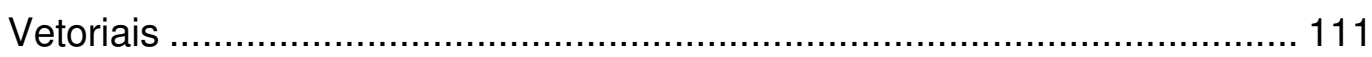

4.2.1 Modelo "Soma" classificado em intervalos iguais............................... 113

4.2.2 Modelo "Soma" classificado em quebras naturais ............................... 115

4.2.3 Modelo "Ponderado" com atribuição equalitária de pesos .................. 116

4.3 Zoneamento Ambiental de Restrições Socioambientais Legais - Dados

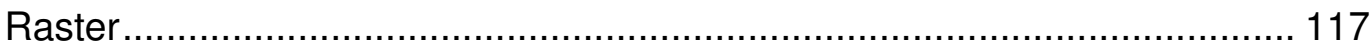

4.3.1 Modelo "Soma Ponderada" com atribuição equalitária de pesos ........ 118

4.3.2 Modelo "Soma Ponderada" com atribuição de pesos diferenciados para as restrições socioambientais legais .................................................... 119

4.3.3 Modelo "Média Ponderada" com atribuição equalitária de pesos e adoção de áreas restritas para pixels de valor 5

4.3.4 Modelo "Média Ponderada" com atribuição equalitária de pesos e adoção de áreas restritas para pixels de valor 5 , exceto os de categoria Áreas Urbanas/Áreas Antropizadas

4.3.5 Modelo "Média Ponderada" com atribuição de pesos diferenciados para as restrições socioambientais legais e adoção de áreas restritas para pixels de valor 5, exceto os de categoria Áreas Urbanas/Áreas Antropizadas 123

4.4 Definição do traçado ferroviário - Análise comparativa ......................... 125

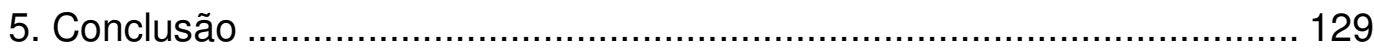

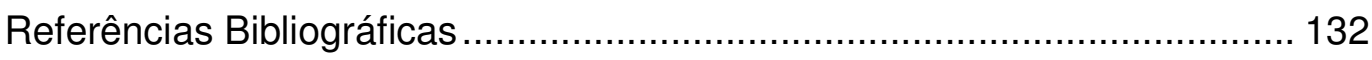




\section{Lista de Figuras}

Figura 1: Esquema de estrutura de um sistema de informações

geográficas. Fonte: INPE. ........................................................... 58

Figura 2: Dados raster e dados vetor. Fonte: INPE................................. 60

Figura 3: Esquema de map overlay. Fonte: ANTT ..................................... 69

Figura 4: Mapa de situação da ferrovia Nova Iguaçu (RJ) - Vila Velha

(ES). Fonte: própria ............................................................... 72

Figura 5: Mapa síntese das restrições socioambientais legais identificadas

em órgãos oficiais. Fonte: própria. ............................................ 74

Figura 6: Processo de Clip. Fonte: ESRI........................................... 76

Figura 7: Processo Buffer. Fonte: ESRI ............................................ 76

Figura 8: Processo Dissolve. Fonte: ESRI .......................................... 82

Figura 9: Processo Merge. Fonte: ESRI............................................... 82

Figura 10: Processo Union. Fonte: ESRI. ............................................. 83

Figura 11: Fluxograma de processamento de dados para Áreas

Prioritárias para Conservação da Biodiversidade. Fonte: própria. .......... 85

Figura 12: Fluxograma de processamento de dados para Mata Atlântica.

Fonte: própria .......................................................................... 86

Figura 13: Fluxograma de processamento de dados para Unidades de

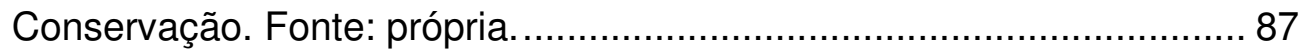

Figura 14: Fluxograma de processamento de dados para Potencial

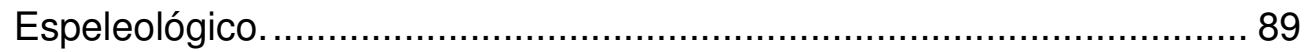

Figura 15: Fluxograma de processamento de dados para Cavidades

Naturais. Fonte: própria............................................................ 90

Figura 16: Fluxograma de processamento de dados para Áreas

Urbanas/Antropizadas. Fonte: própria.............................................. 92

Figura 17: Fluxograma de processamento de dados para Comunidades

Quilombolas. Fonte: própria......................................................... 93

Figura 18: Fluxograma de processamento de dados para Terras

Indígenas. Fonte: própria........................................................... 95 
Figura 19: Fluxograma de processamento de dados de restrições socioambientais legais, para aplicação da equações "média ponderada" e de "soma" dos valores definidos. Fonte: própria. 96

Figura 20: Esquema representativo da ferramenta Weighted Sum. Fonte:

ESRI. 97

Figura 21: Esquema representativo da ferramenta Weighted Overlay.

Fonte: ESRI. 98

Figura 22: Fluxograma de processamento de dados de restrições socioambientais legais, para aplicação das ferramentas Weighted Sum (Soma Ponderada) e Weighted Overlay (Média Ponderada) em dados raster. Fonte: própria. 98

Figura 23 Mapa de Cavidades Naturais e Potencial Espeleológico. Fonte: própria.

Figura 24: Mapa de Unidades de Conservação. Fonte: própria. Fonte: própria. 102

Figura 25: Mapa de Terras Indígenas. Fonte: própria.............................. 103

Figura 26: Mapa de Uso e Ocupação do Solo. Fonte: própria. 107

Figura 27: Mapa de Áreas Prioritárias pra Conservação da Biodiversidade.

Fonte: própria. 108

Figura 28: Mapa do Modelo "Soma" classificado em intervalos iguais.

Fonte: própria.

Figura 29: Mapa do Modelo "Soma" classificado em quebras naturais.

Fonte: própria.

Figura 30: Mapa do Modelo "Ponderado" com atribuição equalitária de

pesos. Fonte: própria.

Figura 31: Mapa do Modelo "Soma Ponderada" com atribuição equalitária de pesos. Fonte: própria. 118

Figura 32: Mapa do Modelo "Soma Ponderada" com atribuição de pesos diferenciados para as restrições socioambientais legais. Fonte: própria. 120

Figura 33: Mapa do Modelo "Média Ponderada" com atribuição equalitária de pesos e adoção de áreas restritas para pixels de valor 5. Fonte: própria. 
Figura 34: Mapa do Modelo "Média Ponderada" com atribuição equalitária de pesos e adoção de áreas restritas para pixels de valor 5, exceto os de categoria Áreas Urbanas/Áreas Antropizadas. Fonte: própria. .

Figura 35: Mapa do Modelo "Média Ponderada" com atribuição de pesos diferenciados para as restrições socioambientais legais e adoção de áreas restritas para pixels de valor 5, exceto os de categoria Áreas Urbanas/Áreas Antropizadas. Fonte: própria.

Figura 36: Mapa do Modelo "Média Ponderada" com atribuição equalitária de pesos e adoção de áreas restritas para pixels de valor 5 , exceto os de categoria Áreas Urbanas/Áreas Antropizadas, contendo o traçado da EF-118 e suas alternativas. Fonte: própria.

Figura 37: Mapa do traçado da EF-118 e suas alternativas propostas.

Fonte: própria. 126

Figura 38: Mapa do traçado da EF-118. Fonte: própria. 127

Figura 39: Mapa de proposta alternativa de traçado para EF-118, considerando aspectos de engenharia. Fonte: própria.

Figura 40: Mapa de proposta alternativa de traçado para EF-118, considerando aspectos de engenharia e do modelo de zoneamento socioambiental de restrições legais elaborado no presente estudo. Fonte: própria. 


\section{Lista de Quadros}

Quadro 1: Participação dos modais na matriz de transportes brasileira

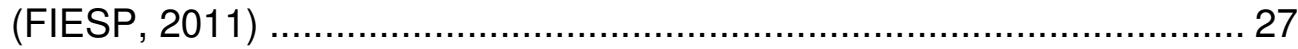

Quadro 2: Investimentos em concessões planejadas em Bilhões de Reais

[Empresa de Planejamento e Logística (EPL), Empresa de Pesquisa

Energética (EPE) e Ministério das Minas e Energia (MME)] .................. 28 


\section{Lista de Tabelas}

Tabela 1: Dados socioambientais legais obtidos em fontes oficiais. 73

Tabela 2: Valores atribuídos para Áreas Prioritárias para Conservação de

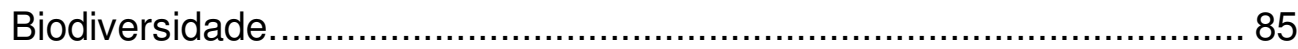

Tabela 3: Valores atribuídos para Mata Atlântica....................................... 86

Tabela 4: Valores atribuídos para Unidades de Conservação. ...................... 88

Tabela 5: Valores atribuídos para Potencial Espeleológico. ........................ 89

Tabela 6: Valores atribuídos para Cavidades Naturais. ............................... 90

Tabela 7: Valores atribuídos para Áreas Urbanas/Antropizadas................... 92

Tabela 8: Valores atribuídos para Comunidades Quilombolas..................... 94

Tabela 9: Valores atribuídos para Comunidades Terras Indígenas. .............. 95

Tabela 10: Dados socioambientais identificados em bases públicas oficiais e seus respectivos valores, definidos para o presente estudo............. 109

Tabela 11: Pesos atribuídos às restrições socioambientais legais............... 119

Tabela 12: Pesos atribuídos as restrições socioambientais legais............... 124 


\section{Lista de Equações}

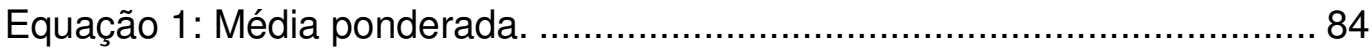

Equação 2: Soma dos valores presentes na tabela de atributos dos dados de restrições socioambientais legais obtidas em bases públicas oficiais.

Equação 3: Média ponderada dos valores presentes na tabela de atributos dos dados de restrições socioambientais legais obtidas em bases públicas oficiais. 


\section{Introdução}

\subsection{Contextualização}

Segundo o Banco Mundial, no ano de 2014, o Brasil alcançou a $7^{\mathrm{a}}$ maior economia do mundo, correspondendo por $50 \%$ da economia Sul-Americana.

De acordo com dados do Ministério de Desenvolvimento, Indústria e Comércio Exterior apresentados na página eletrônica do Programa de Investimento em Logística - PIL, o mercado consumidor no Brasil possui mais de 100 milhões de consumidores, representando o $8^{\circ}$ maior do mundo. No que se refere à produção de alimentos é o maior produtor de café, cana de açúcar, laranja e soja em grão. No setor industrial, possuiu a maior e mais diversificada base da América Latina e do Caribe. Atualmente é fornecedor mundial de recursos naturais, sendo o $2^{\circ}$ maior produtor de minério de ferro e líder mundial na produção de celulose de eucalipto, coma maior indústria de base florestal da América Latina.

Ainda de acordo com o Ministério do Desenvolvimento, Indústria e do Comércio Exterior, o Brasil é o $20^{\circ}$ maior exportador do mundo, sendo o maior na exportação em de café, suco de laranja, açúcar, grãos de soja, carne bovina e carne de frango. Ainda possui áreas disponíveis para a expansão da agricultura e a maior extensão de terras agrícolas do mundo.

Com tamanha diversidade de atividades econômicas, o sistema de transporte é vital para a movimentação da economia de um país, pois, sem ele os produtos não chegariam até seus consumidores, as indústrias não teriam acesso as matériasprimas e nem teriam condições de escoar sua produção. Esse sistema viabiliza todos os outros setores da economia. Porém, segundo Wanke e Fleury (2006, p. 417) existem aspectos que prejudicam o setor: 
Atualmente, o sistema de transportes brasileiro encontra-se numa encruzilhada. De um lado, um forte movimento de modernização nas empresas, que demandam serviços logísticos cada vez mais eficientes, confiáveis e sofisticados, a fim de manterem-se competitivas num mundo que se globalizou, e onde a logística é, cada vez mais, determinante para o sucesso empresarial. De outro, um conjunto de problemas estruturais, que distorcem a matriz de transportes brasileiro e contribuem para o comprometimento, da qualidade dos serviços, da saúde financeira dos operadores e principalmente do desenvolvimento socioeconômico do país.

$\mathrm{Na}$ origem dos problemas estruturais estão as questões de priorização de investimentos em geral, atribuída à opção do governo pelo investimento majoritário em rodovias desde a década de 1950 até a década de 1970, período esse de implantação da indústria automobilística no país e da mudança da capital para a Região Centro-Oeste [Goldenstein et al (2006), Schroeder e Castro (1996)]. Além disso, existem falhas na regulação, na fiscalização e no custo de capital, o que pode explicar a dependência exagerada do modal rodoviário e, como consequência, nota-se baixos índices de produtividade, insegurança nas estradas, a baixa eficiência energética e a altos níveis de poluição ambiental.

De acordo com os dados da Federação das Indústrias do Estado de São Paulo (FIESP, 2011), a matriz de transporte brasileira apresenta os seguintes números, conforme Quadro 1 a seguir:

\begin{tabular}{|l|l|}
\hline \multicolumn{1}{|c|}{ Modal } & \multicolumn{1}{|c|}{$\begin{array}{c}\text { Participação percentual na matriz de } \\
\text { transportes brasileira }\end{array}$} \\
\hline Rodoviário & $59 \%$ \\
\hline Ferroviário & $24 \%$ \\
\hline Aquaviário & $13 \%$ \\
\hline Aeroviário & $0,3 \%$ \\
\hline Dutoviário & $3,7 \%$ \\
\hline
\end{tabular}

Quadro 1: Participação dos modais na matriz de transportes brasileira. Fonte: Revista Logística, 2013.

Apesar desses dados, existe uma perspectiva de mudança da matriz com maior participação do modal ferroviário. Prova disso é que o governo estima que através do Plano Nacional de Logística de Transportes - PNLT a participação do 
modal rodoviário se reduzirá para $33 \%$ em 2025, enquanto as participações dos modais ferroviário e aquaviário aumentarão para $32 \%$ e $29 \%$, respectivamente.

Nesse contexto, no âmbito do PNLT, em agosto de 2012, o Governo Federal lançou o Programa de Investimentos em Logística (PIL). Tal programa inclui um conjunto de projetos que poderão contribuir para o desenvolvimento de um sistema de transportes mais moderno em busca de maior eficiência e sendo conduzidos por meio de parcerias estratégicas com o setor privado, de forma a promover sinergias entre as redes rodoviária e ferroviária, hidroviária, portuária e aeroportuária.

No Quadro 2 a seguir, são apresentados números do governo brasileiro que confirmam essa tendência, uma vez que o mesmo prevê investimentos em logística de transportes na ordem de 242 Bilhões divididos em:

\begin{tabular}{|l|l|}
\hline \multicolumn{1}{|c|}{$\begin{array}{c}\text { Investimentos em concessões } \\
\text { planejadas }\end{array}$} & \multicolumn{1}{c|}{ Bilhões (R\$) } \\
\hline Rodovias & 42 \\
\hline Ferrovias & 91,1 \\
\hline Portos & 54,6 \\
\hline Trens de alta velocidade & 35,6 \\
\hline Aeroportos & 18,7 \\
\hline Total & 242 \\
\hline
\end{tabular}

Quadro 2: Investimentos em concessões planejadas em Bilhões de Reais. Fonte:[Empresa de Planejamento e Logística (EPL), Empresa de Pesquisa Energética (EPE) e Ministério das Minas e Energia (MME)]

Como pode ser observado, no setor ferroviário, o programa prevê o maior aporte de investimentos, na ordem de $\mathrm{R} \$ 90$ bilhões, em construção e/ou melhoramentos de 11 mil $\mathrm{km}$ de linhas férreas.

Os motivos para tal escolha podem ser entendidos a partir da ótica de otimização do transporte, uma vez que a ferrovia apresenta vantagem competitiva em termos econômicos, ideal para grandes volumes, longas distâncias e produtos de baixo valor agregado, como por exemplo, commodities. Já o transporte 
rodoviário é adequado para produtos de médio e alto valor agregado para médias e curtas distâncias e para operações "porta a porta".

Ao mesmo tempo em que os investimentos em transporte se expandem, com o consequente aumento da malha ferroviária, crescem também as preocupações com o meio ambiente, presentes em debates nacionais e internacionais.

Para ilustrar o peso que as questões ambientais ganharam a partir de então, o número de Unidades de Conservação e a extensão por elas protegida vêm crescendo aceleradamente nas últimas décadas no Brasil, nas três esferas governamentais. Esse crescimento é fundamental para garantir a conservação dos recursos naturais, sobretudo no Brasil, por ser reconhecido por abrigar uma variedade de seres vivos distribuídos por vários biomas e diversos ecossistemas.

\subsection{Justificativa}

Uma vez que a malha ferroviária irá expandir-se em um cenário em que as questões ambientais ganham cada vez mais importância, faz-se necessário uma maior compreensão do território e dos riscos associados ao seu uso.

Portanto as ferramentas de análise espacial são essenciais para que o planejamento da ocupação do solo esteja alinhado com as bases legais de conservação e preservação ambiental. Através do zoneamento ambiental é

possível identificar áreas territoriais mais ou menos favoráveis ao desenvolvimento de atividades econômicas, como por exemplo, a construção de linha férrea, antes de sua execução. Assim, o empreendedor pode visualizar alternativas locacionais mais adequadas, evitando complicações futuras no licenciamento ambiental.

Nesse contexto, o presente trabalho irá apresentar uma metodologia para zoneamento socioambiental, calcado na legislação pertinente, através da aplicação de técnicas de geoprocessamento, em especial a análise espacial utilizando ferramentas de map overlay que oferecerão subsídios para a tomada de decisão quanto a melhor alternativa locacional de empreendimentos de infraestrutura. 
Desta forma, será apresentado o estudo de caso da ferrovia que liga a cidade de Nova Iguaçu no Rio de Janeiro à cidade de Cariacica no Espírito Santo e teve sua construção executada em épocas e condições diversas por diferentes empresas em trechos segmentados, que aos poucos foram sendo unidos até compor a The Leopoldina Railway pelo setor privado, entre 1889 e 1930. Posteriormente, entre 1930 e 1960 foi nacionalizada como E. F. Leopoldina e entre os anos de 1960 e 1990, sobretudo durante o regime militar, passou à Rede Ferroviária Federal S.A. - RFFSA, até finalmente voltar para a administração do setor privado como Ferrovia Central Atlântica - FCA.

A força motriz da construção dessa ferrovia, além de abrir diversas interligações locais, foi estabelecer uma ligação entre Rio de Janeiro e Vitória para o transporte de cargas diversificadas que variaram ao longo do tempo, predominantemente o açúcar, o cimento, os derivados de petróleo (entre a Reduc e Campos), o álcool (no sentido inverso), cana de açúcar (em trechos locais próximos às antigas usinas, mas extinto há anos), calcário, areia, mármore, toretes de madeira entre outros.

O trecho em estudo para a atual concessão situa-se entre Nova Iguaçu - RJ e Cariacica - ES e é conhecido pelo nome EF-118. Porém, no caso da linha original da E. F. Leopoldina, seu ponto de partida é na cidade do Rio de Janeiro, na antiga Estação Barão de Mauá, atual Estação Leopoldina e seu ponto final na cidade de Vila Velha, na Estação de Vitória, que apesar do nome, está do outro lado da Baía de Vitória. Assim, a linha tronco da E. F. Leopoldina tem nominalmente 638,311 km (levantamento em 1960, segundo pesquisa do Ralph Giesbrecht, no site).

Depois de alguns anos de declínio das atividades produtivas no Norte Fluminense e Sul Capixaba que justificassem maiores investimentos e manutenção da linha e do deslocamento dos centros produtores para São Paulo e Minas Gerais, a mesma foi desativada e praticamente abandonada. Com a mudança, sobretudo econômica desse cenário, o trecho conhecido como EF-118 vem sendo estudado para reativação. Prevê-se um fluxo de cargas, inclusive contêineres, entre os portos e centros industriais da Grande Vitória, Porto Central (a ser construído no município de Presidente Kennedy, ES), Porto do Açu (em 
São João da Barra, RJ), Comperj, Reduc e os portos do Grande Rio (Rio de Janeiro e Itaguaí).

Dessa forma e por ocasião do Programa de Investimentos em Logística (PIL) e da demanda do setor produtivo, especialmente os produtores de commodities o governo federal irá licitar a reativação dessa linha férrea, porém o seu traçado atual deverá ser reavaliado para adequações por força de questões técnicas diversas, dentre elas, a ambiental.

\subsection{Objetivos}

Avaliar metodologia de zoneamento de restrições socioambientais legais ao uso e ocupação do solo, utilizando ferramentas de geoprocessamento para subsidiar a escolha de traçado de ferrovias, através do estudo de caso da via EF118, Nova Iguaçu (RJ) - Cariacica (ES).

- Analisar os conceitos de geotecnologias e a aplicação de ferramentas de análise espacial como auxílio à gestão territorial, compreendendo o planejamento e zoneamento ambiental.

- Identificar e analisar os dados socioambientais legais disponíveis em bases públicas e órgãos oficiais, para composição de base de dados espaciais sobre o tema.

- Análisar modelos de dados para zoneamento ambiental a partir do estudo de caso da ferrovia Nova Iguaçu (RJ) - Cariacica (ES), para identificação de restrições socioambientais legais ao traçado ferroviário.

- Discutir e comparar o traçado existente da via férrea desativada e o novo traçado proposto à luz da legislação ambiental. 


\subsection{Estrutura da dissertação}

Esta pesquisa de mestrado foi desenvolvida segundo a elaboração de cinco capítulos, descritos a seguir:

A contextualização, justificativa e objetivos da pesquisa são apresentados no Capítulo 1.

No Capítulo 2 apresenta-se a fundamentação da pesquisa, através da análise da legislação ambiental no Brasil. Também será elaborado estudo de iniciativas de planejamento e zoneamento ambiental, seus conceitos e exemplos de aplicação na gestão territorial. Além disso, são analisados conceitos de geotecnologias e seu uso como ferramenta auxiliar à gestão territorial, sobretudo em aspectos relacionados ao meio ambiente.

No Capítulo 3 são apresentados os materiais e procedimentos adotados para pesquisa e processamento de dados espaciais socioambientais legais, disponíveis em órgãos públicos.

No Capítulo 4 descreve-se o estudo de caso e os resultados da aplicação do Map Overlay, como produto de análise espacial através do uso de ferramentas de geotecnologias. Se obtem assim o zoneamento de restrições socioambientais legais ao uso e ocupação do solo. Inicialmente escolhe-se, entre os métodos apresentados no capítulo 2, qual melhor se adapta ao planejamento e zoneamento socioambiental para identificação de áreas mais ou menos restritivas do ponto de vista legal a empreendimentos ferroviários, apresentando os argumentos utilizados para isso. Parte-se então para uma adaptação do método às peculiaridades da ferrovia. Para isso é necessário definir quais os critérios envolvidos na análise e o motivo dessa escolha.

E, por fim, no Capítulo 5 apresentam-se as conclusões obtidas pelo processo analítico, o relato das limitações da pesquisa e algumas recomendações para trabalhos futuros bem como para sanar possíveis pontos falhos identificados no método de análise utilizado neste trabalho. 


\section{Referencial Teórico}

\subsection{Legislação Ambiental}

O ponto de partida para o objetivo que se deseja alcançar no presente estudo é uma análise da legislação ambiental brasileira, que abarca aspectos sociais, aspectos de meio físico e aspectos de meio biótico. É a legislação que norteará os levantamentos de dados espaciais socioambientais com o intuito de se mapear as principais restrições de uso e ocupação do solo previstos em Lei. Através de pesquisa bibliográfica, será levantada a legislação ambiental brasileira, para identificação de potenciais restrições e limitações de uso e ocupação do solo e à construção de empreendimentos.

A par da evolução das reflexões e demandas sociais acerca dos impactos ambientais de grandes projetos, buscou-se constituir um mecanismo de gestão ambiental, de caráter preventivo, que subsidiasse a tomada de decisão dos setores públicos acerca de políticas, planos, programas e projetos de desenvolvimento. $\mathrm{O}$ modelo adotado nos diversos países incorporou características da "National Environmental Policy Act (NEPA)", regulamentação norte-americana, de 1969, que instituiu a Avaliação de Impacto Ambiental na forma de uma Declaração de Impacto Ambiental (Environmental Impact Statement/EIS), cuja eficiência repercutiu, entre outros aspectos, na efetividade da participação da sociedade civil no processo de decisão acerca viabilidade ambiental dos empreendimentos.

Progressivamente, alguns países agregaram a Avaliação de Impacto Ambiental ao seu arcabouço legal e administrativo: Alemanha em 1971, Canadá em 1973, França em 1976. Em 1974, a Colômbia instituiu o Código Nacional de los Recursos Naturales Renovables y la Protección Ambiental dispondo sobre a apresentação de relatórios de impacto ambiental para atividades causadoras de danos ambientais. 
No Brasil, os desdobramentos da Conferência de Estocolmo não tardaram a repercutir e, já na década de 70 , projetos de grande vulto, sob o crivo de organismos multilaterais de financiamento, foram submetidos à Avaliação de Impacto Ambiental, caso da Usina Hidrelétrica de Sobradinho, primeiro empreendimento a sofrer uma avaliação ambiental no Brasil no ano de 1972. As experiências em avaliação de impacto ambiental sucederam-se na década de 70 , culminando na consagração desta, como instrumento da Política Nacional de Meio Ambiente, Lei $n^{\circ}$ 6938/81, em associação ao licenciamento das atividades utilizadoras dos recursos ambientais, consideradas efetiva ou potencialmente poluidoras.

Segundo BRAGA et al (2005) com uma melhor compreensão dos efeitos resultantes das atividades humanas sobre o meio ambiente, houve uma evolução no modelo de regulamentação ambiental, que passou a incorporar os conceitos de planejamento e gerenciamento dos recursos naturais, além dos mecanismos de coerção.

\subsubsection{Legislação Ambiental Brasileira}

Com o intuto de respaldar o presente trabalho, buscou-se apresentar, a seguir, os prinicpais marcos da legislação ambiental brasileira que é considerada uma das mais avançadas do mundo.

A Constituição Federal dedica o Capítulo VI ao tema, estabelecendo que todos os brasileiros têm direito ao meio ambiente ecologicamente equilibrado, de uso comum e essencial, cabendo ao Poder Público e à sociedade o dever de defendê-lo e de preservá-lo.

Segundo a Constituição Federal, é dever do Estado:

a) preservar e recuperar as espécies e os ecossistemas;

b) preservar a variedade e a integridade do patrimônio genético, supervisionando as entidades envolvidas em pesquisa e em manipulação genética; 
c) proporcionar educação ambiental em todos os níveis escolares, orientando quanto à necessidade de preservação do meio ambiente;

d) definir as áreas territoriais a serem protegidas;

e) exigir estudo de impacto ambiental para instalação de qualquer atividade que possa causar significativa degradação ao meio ambiente.

A Política Nacional de Meio Ambiente, Lei $n^{\circ}$ 6938, editada em 31 de agosto de 1981, tem como instrumentos para sua execução a avaliação de impacto ambiental e o licenciamento de atividades efetiva ou potencialmente poluidoras. A Política reconhece que a proteção jurídica ao meio ambiente demanda ações descentralizadas, em que Estados e municípios se tornam executores de medidas e tomadores de providências.

A proteção ao meio ambiental é feita, em escala federal, pelos seguintes órgãos públicos, que, juntos, compõem o Sistema Nacional de Meio Ambiente (SISNAMA):

a) Conselho Nacional do Meio Ambiente (CONAMA): órgão normativo, consultivo e deliberativo;

b) Ministério do Meio Ambiente (MMA): órgão coordenador, supervisor e controlador da Política Nacional de Meio Ambiente;

c) Instituto Brasileiro do Meio Ambiente e dos Recursos Naturais Renováveis (Ibama): órgão executivo, que fiscaliza a atividade empresarial em caráter nacional.

No âmbito da Lei $n^{\circ}$ 6938/81 foi instituído o Conselho Nacional do Meio Ambiente/CONAMA, órgão responsável pelo estabelecimento de normas e critérios para o licenciamento ambiental. 
Considerando a necessidade de se estabelecerem definições, responsabilidades, critérios básicos e diretrizes para o uso e implementação da avaliação de impacto ambiental, o CONAMA publicou, em 23 de janeiro de 1986, a Resolução $\mathrm{n}^{\circ}$ 001, submetendo o licenciamento ambiental de determinadas atividades modificadoras do meio ambiente à elaboração de estudo de impacto ambiental e respectivo relatório de impacto ambiental/EIA/RIMA.

A evolução das experiências de licenciamento nos órgãos de meio ambiente do país, demonstrou a importancia de revisão dos procedimentos e critérios utilizados no licenciamento, dando oportunidade para publicação da Resolução CONAMA nº 237 em 19 de dezembro de 1997. Tal Resolução estabeleceu regras, em normas gerais, a diferenciação das competências para o licenciamento nas três esferas administrativas, a saber: federal, estadual e distrital. Além disso, regulamentou as etapas do procedimento de licenciamento pelos empreendimentos passíveis do citado processo, conforme estabelece a legislação.

Em 1998, a edição da Lei $n^{\circ}$ 9605, de 12 de fevereiro, Lei de Crimes Ambientais, enquadrou à condição de crime condutas danosas ao meio ambiente, oriundas de negligência ou omissão da regulamentação prevista no licenciamento ambiental. A partir de então, são considerados crime ambiental a construção, reforma, ampliação, instalação ou funcionamento, em qualquer parte do território nacional, de estabelecimentos, obras ou serviços potencialmente poluidores, sem licença ou autorização dos órgãos ambientais competentes ou contrariando as normas legais e regulamentares pertinentes ao licenciamento (Art. 60 da Lei ${ }^{\circ}$ 9605/98). A criminalização das práticas danosas ao meio ambiente, agregada ao sistema de licenciamento ambiental, é um importante marco para a responsabilização social e consolidação institucional do licenciamento como instrumento de gestão ambiental.

Em 18 de julho de 2000 foi instituído o Sistema Nacional de Unidades de Conservação - SNUC, através da Lei Federal no 9.985, que define unidade de conservação como: 
“(...) espaço territorial e seus recursos ambientais, incluindo as águas jurisdicionais, com características naturais relevantes, legalmente instituído pelo Poder Público, com objetivos de conservação e limites definidos, sob regime especial de administração, ao qual se aplicam garantias adequadas de proteção".

Para Milano (1983), o objetivo destas unidades é assegurar bons níveis de qualidade de vida a sociedade. Além de passar por questões políticas de ordem econômica e social, sua criação abrange necessariamente questões de ordem ecológica. Para tanto, o uso adequado do solo e dos demais recursos naturais, entendidos como ecossistemas, deve ser convenientemente considerado.

O Sistema Nacional de Unidades de Conservação (BRASIL, 2000) agrupa as categorias de unidades de conservação com características específicas em dois grupos básicos: de Proteção Integral e de Uso Sustentável. O objetivo básico das unidades de Proteção Integral é preservar a natureza, sendo admitido apenas o uso indireto dos seus recursos naturais, enquanto as unidades de Uso Sustentável visam compatibilizar a conservação da natureza com o uso sustentável de parcela dos seus recursos naturais.

No grupo das unidades de Proteção Integral estão as seguintes categorias, segundo o SNUC:

- Estação Ecológica: tem o objetivo de preservar a natureza e realizar pesquisas científicas, é de domínio público, a visitação pública é proibida, exceto com objetivo educacional, a pesquisa depende de autorização prévia do órgão responsável pela administração e não podem causar impactos maiores sobre o ambiente do que a coleta controlada de componentes do ecossistema ou a simples observação;

- Reserva Biológica: tem como objetivo a preservação integral da biota e demais atributos naturais, sem interferência humana direta ou modificações ambientais;

- Parque (Nacional, Estadual ou Municipal): tem como objetivo básico a preservação de ecossistemas naturais de grande relevância ecológica e beleza cênica, oferecer campo para pesquisas, educação ambiental, recreação e turismo ecológico; 
- Monumento Natural: tem como objetivo básico preservar sítios naturais raros, singulares, ou de grande beleza cênica;

- Refúgio da Vida Silvestre: tem como objetivo proteger ambientes naturais onde existem condições para a reprodução de espécies da flora local e da fauna residente ou migratória.

No grupo das unidades de Uso Sustentável estão as seguintes categorias segundo o SNUC:

- Área de Proteção Ambiental: geralmente apresenta área extensa, com o objetivo de preservar a diversidade biológica, podendo ser ocupada por certo grau de população humana, disciplinar o processo de ocupação e assegurar a sustentabilidade do uso dos recursos naturais também são objetivos de uma APA;

- Área de Relevante Interesse Ecológico: geralmente é pequena em extensão, com pouca ou nenhuma ocupação humana, com características naturais extraordinárias ou que abriga exemplares raros da biota regional;

- Floresta (Nacional, Estadual ou Municipal): é a categoria que admite a permanência de populações tradicionais que vivem na área antes da criação, tem como objetivo básico o uso múltiplo sustentável dos recursos florestais e a pesquisa científica;

- Reserva Extrativista: é a área utilizada pelas populações extrativistas tradicionais, e tem como objetivos básicos proteger os meios de vida e a cultura destas populações e assegurar o uso sustentável dos recursos naturais da unidade;

- Reserva de Fauna: é uma área natural com populações animais, adequada para estudos técnico-científicos sobre recursos faunísticos; 
- Reserva do Desenvolvimento Sustentável: tem como objetivo básico preservar a natureza, e assegurar condições de melhorias da qualidade de vida das populações tradicionais;

- Reserva Particular do Patrimônio Natural: tem o objetivo de conservar a diversidade biológica, a pesquisa científica e a visitação com objetivos turísticos, recreativos e educacionais.

Outro importante marco foi a revisão do Código Florestal, através da Lei no 12.651/2012, que, entre outros aspectos, dispõe sobre a proteção da vegetação nativa e sua compatibilização com o agronegócio. Segundo o Novo Código Florestal, Área de Preservação Permanente é uma área protegida, coberta ou não por vegetação nativa, com a função ambiental de preservar os recursos hídricos, a paisagem, a estabilidade geológica e a biodiversidade, facilitar o fluxo gênico de fauna e flora, proteger o solo e assegurar o bem-estar das populações humanas.

$\mathrm{O}$ atual arcabouço jurídico-institucional do sistema de licenciamento ambiental brasileiro reproduz as experiências, reflexões e sistematização de mais de duas décadas consagradas à gestão de impactos ambientais de obras, atividades e projetos, nos setores público e privado. Sua consolidação, no âmbito das instituições e da sociedade, mantém-se em construção, atento às transformações e demandas sociais e ao resguardo do princípio fundamental do meio ambiente ecologicamente equilibrado como patrimônio público, direito e dever de toda a coletividade.

\subsubsection{Licenciamento Ambiental}

O licenciamento ambiental é ato administrativo pelo qual o órgão ambiental competente (federal, estadual ou municipal) estabelece as condições, as restrições e as medidas de controle ambiental que deverão ser observadas pelas empresas para instalação, ampliação, operação de empreendimentos ou de atividades que utilizem recursos naturais e que sejam consideradas efetiva ou potencialmente poluidoras, ou que, de alguma forma, possam causar degradação ao meio ambiente. 
Compete ao Ibama conceder licença ambiental quando o empreendimento tem impacto regional ou nacional, provocando alteração adversa das propriedades físicas, químicas e biológicas do meio ambiente. Não obstante, ao órgão ambiental estadual compete a concessão de licenciamento ambiental a empreendimentos e a atividades que se situem em mais de um município, ou cujo impacto ambiental ultrapasse os limites territoriais de um ou mais municípios.

Caso o empreendimento ou atividade cause impacto ambiental local, isto é, apenas dentro do limite do território municipal, compete aos órgãos municipais a concessão ou não da licença. Alguns municípios, em razão da precária estrutura administrativa, transferem ao órgão estadual a competência para concessão de licenças.

A Resolução 237, de 1997, do CONAMA estabelece as atividades e os empreendimentos que obrigatoriamente estão sujeitos à obtenção de licenciamento ambiental:

a) extração e tratamento de minerais;

b) indústria de produtos minerais não metálicos;

c) indústria metalúrgica;

d) indústria mecânica;

e) indústria de material de transporte;

f) indústria da madeira;

g) indústria de papel e celulose;

h) indústria da borracha;

i) indústria de couros e peles; 
j) indústria química;

k) indústria de produtos de matéria plástica;

1) indústria têxtil, de vestuário, calçados e artefato de tecidos;

m) indústria de produtos alimentares e bebidas;

n) indústria de fumo;

o) indústrias diversas;

p) obras civis;

q) serviço de utilidade pública (energia e resíduos);

r) transporte, terminais e depósitos;

s) turismo;

t) atividades agropecuárias;

u) uso de recursos naturais.

O procedimento administrativo de licenciamento ambiental compreende a obtenção das seguintes licenças:

a) Licença Prévia (LP) - emitida na fase de planejamento de uma atividade, contém as exigências básicas a serem atendidas pelo projeto para a sua localização, instalação e funcionamento, com base nas regras de uso do solo, zoneamento industrial e legislação urbanística; 
A LP atesta a viabilidade ambiental, sendo necessário definir nesta fase, a melhor alternativa locacional de empreendimentos. Nesse contexto o presente estudo se configura como etapa preliminar, de planejamento, para obtenção da LP.

b) Licença de Instalação (LI) - documento emitido após a análise do projeto executivo do empreendimento e da apresentação dos projetos que demonstrem o cumprimento das exigências impostas pela licença prévia; das soluções adotadas para a neutralização, a mitigação ou a compensação dos impactos ambientais e os procedimentos de controle ambiental. A obtenção dessa licença autoriza a execução dos projetos aprovados;

c) Licença de Operação (LO) - documento que autoriza o início das atividades de determinada indústria ou empreendimento, uma vez verificado o correto funcionamento dos equipamentos de controle de poluição.

É importante destacar ainda a Portaria Interministerial $N^{\circ} 419$, de 26 de outubro de 2011 que regulamenta a atuação dos órgãos e entidades da Administração Pública Federal envolvidos no licenciamento ambiental, tais como Fundação Nacional do Índio-FUNAI, da Fundação Cultural Palmares-FCP, do Instituto do Patrimônio Histórico e Artístico Nacional-IPHAN e do Ministério da Saúde, incumbidos da elaboração de parecer em processo de licenciamento ambiental de competência federal, a cargo do Instituto Brasileiro do Meio Ambiente e dos Recursos Naturais Renováveis-IBAMA. O Anexo II dessa Portaria estabele distâncias mínimas a serem respeitadas pelos empreendimentos em relação a terras Indígenas, Quilombolas.

\subsection{Planejamento Ambiental}

Segundo CONYERS e HILLS (1984) o planejamento é "um processo contínuo que envolve decisões ou escolhas, sobre modos alternativos de usar os recursos disponíveis, com o objetivo de alcançar metas específicas em algum momento no futuro". A definição apresentada pelos autores engloba os principais pontos incluídos em demais definições expressando os passos mais significativos de planejamento, a saber: a tomada de decisão ou escolha envolvendo as diversas 
maneiras alternativas, e qual a melhor para se alcançar os mesmos objetivos; o uso ou alocação de recursos, que podem ser naturais, humanos, financeiros ou de infraestrutura; os caminhos alternativos para alcançar as metas traçadas, envolvendo metas realísticas, decisões políticas e participação popular; e, finalmente, planejando para o futuro, que envolve prognóstico ou previsões aproximadas do que pode acontecer e, mais especificamente, previsão dos resultados das alternativas propostas, que determina qual delas deverá ser adotada.

Para BARRETO (2000) o planejamento é uma atividade, não estática, de muitos fatores concomitantes, que têm de ser coordenados para se alcançar um objetivo que está em outro tempo.

De acordo com OREA (1994):

O planejamento é um processo racional de tomada de decisões para a definição de uma imagem objetiva coerente e de um rumo futuro de ação e previsão orientada a conseguí-la, que pretende resolver os problemas atuais, prevenir os potenciais, satisfazer as necessidades e aspirações futuras, e aproveitar as oportunidades do sistema sócio-físico (...) todas e cada uma das múltiplas formas: nacional, regional, local, particular; integral e setorial; física, econômica e social; espacial; urbana e rural; a curto, médio ou longo prazo.

Isto pode ser obtido por via da ordenação territorial ou seu equivalente, o planejamento integral. Segundo esse mesmo autor, o planejamento é o veículo de integração e previsão ambiental.

VAN LIER (1994) acredita no planejamento através do uso sustentável da terra, propondo a incorporação deste, tanto na formulação quanto na execução das políticas. Ressalta ainda que é preciso atender as necessidades de uso, num futuro de curto prazo, tais como: produtos alimentícios para manutenção da vida, produção industrial, espaços para lazer, áreas reservadas para assegurar a existência de plantas e animais. Para o autor, dastacam-se duas dimensões do planejamento: uma relacionada às políticas de uso da terra e outra relacionada aos planos de melhoria das condições espaciais e físicas do meio. A primeira dimensão refere-se às políticas e estudos para se decidir quais os tipos de atividades serão implantadas e quais locais são apropriados. Freqüentemente, essa prática é chamada de planejamento físico ou plano de uso da terra, idéia similar a 
zoneamento, a ser tratado mais adiante. A segunda dimensão do conceito refere-se às mudanças de uso impulsionadas por atores sociais e das condições físicas da terra, que na maioria dos casos de planejamento de uso da terra segue o planejamento físico, que é monitorado e reavaliado constantemente. Esta segunda dimensão confere dinamismo ao planejamento físico porque é responsável pela realocação, a reconstrução de projetos e, freqüentemente, pela melhoria das condições físicas para distintos usos da terra, conforme a necessidade da sociedade. $\mathrm{Na}$ prática as duas dimensões citadas estão fortemente vinculadas, podendo inclusive confundirem-se em determinados momentos, porém de certa forma, pode-se dizer sinteticamente que a primeira dimensão trata da formulação de alternativas e a segunda trata da sua execução.

Segundo VAN DE LAAK (1994) o planejamento, rotulado como regional, tem como proposta influenciar o desenvolvimento de dada região. Neste sentido, os responsáveis pela aplicação das políticas normalmente se deparam com duas questões: como influenciar o desenvolvimento de uma região? E qual a direção que se deseja direcionar o desenvolvimento? A primeira resposta deve basear-se nas informações sobre os mecanismos que controlam o desenvolvimento da região, de tal forma que a percepção destes mecanismos permita orientar a criação de instrumentos adequados que possam influenciá-los. A segunda questão, comumente, leva ao conflito entre crescimento econômico e qualidade ambiental. O ideal é almejar o desenvolvimento com a associação de múltiplos objetivos, priorizando a sustentabilidade.

DORNEY (1989) define o Planejamento ambiental como uma prática que "inclui um conjunto de metas, análise de informações, audiências e aprovações". O planejador ambiental procura desvendar a dinâmica ecossistêmica e, em função disto, desenvolve o planejamento ambiental buscando realizar um ajuste satisfatório entre a sociedade e a natureza.

O planejamento ambiental para CHRISTOFOLETTI (1999) envolve-se com os programas de utilização dos sistemas ambientais, como elemento condicionante de planos nas escalas espaciais do local, regional e nacional, uso do solo rural, execução de obras de engenharia e planejamento econômico. Em função de 
focalizar os ecossistemas e os geossistemas (sistema físico), os seus objetivos podem sublinhar perspectivas ecológicas e geográficas. O autor defende o saber geográfico como base para o planejamento ambiental.

Para FRANCO (2001) o planejamento ambiental é "todo esforço da civilização na direção da preservação e conservação dos recursos ambientais de um território, com vistas à sua própria sobrevivência”.

Nas últimas décadas o termo planejamento ambiental ganhou importância, tanto no mundo, quanto no Brasil. Inicialmente correspondendo ao ordenamento do espaço natural, evoluiu passando a ser compreendido como processo de planejamento integrador dos fatores ambientais, sociais e econômicos. "Ele nada mais é do que o próprio planejamento" (PARTIDÁRIO, 1999), destacando o rótulo "ambiental" como forma de reforçar a idéia de que conceitos e critérios usados em planejamento deveriam ser moldados a uma nova realidade que demanda a inserção da variável ambiental. Ou seja, não existe planejamento descolado de variáveis ambientais.

Dentro do contexto europeu, fala-se em planejamento espacial, sem qualificá-lo como ambiental, por se considerar que aspectos de meio ambiente são intríncecos ao planejamento. $\mathrm{O}$ mesmo trabalha como uma forma de alinhar as considerações dos fatores ecológicos aos socioeconômicos do espaço, servindo como base para o desenvolvimento sustentável (ALEMANHA, 2001), tendo o conceito de desenvolvimento espacial como diretriz para os planos nacionais dos países membro da União Européia (SCHOLL; ELGENDY; NOLLERT, 2007).

O Federal Office for Building and Regional Planning (ALEMANHA, 2001) elaborou documento onde comenta-se a relevância do desenvolvimento espacial sustentável como garantia de qualidade de vida, ao considerar que atividades econômicas e sociais estão sempre em mutação e causam novos e diferentes impactos ao espaço. Como exemplo pode-se elencar: a expansão das cidades, diminuição da paisagem natural e de áreas verdes, abandono de áreas agricultáveis, dentre outros. Diversos são os atores sociais que influenciam e transformam o espaço, alterando seu uso ao sabor de seus interesses e atividades. 
Aspectos similares, como abordagem integrada, elaboração de um conjunto de programas relacionados, especificações de objetivos futuros, avaliação da possibilidade e formação de suporte para sua implementação, são consideradas por WESTMAN (1985) e SMITH (1993).

SANTOS (2004) sustenta que 1981 foi o ano em que as primeiras iniciativas para o planejamento ambiental foram desenvolvidas no Brasil, com a orientação para o ordenamento territorial, prova disso é que a Política Nacional de Meio Ambiente de 1981 - PNMA - já tinha em seus princípios, objetivos e instrumentos, as normas legais para atingir o ideal de meio ambiente equilibrado e de uso comum (RANIERI et al., 2005). Posteriormente a Constituição Federal brasileira de 1988 se apropria desse ideal embrionário presente na PNMA de 1981 e define no artigo 225 que "Todos têm direito ao meio ambiente ecologicamente equilibrado, bem de uso comum do povo e essencial à sadia qualidade de vida, impondo-se ao poder público e à coletividade o dever de defendê-lo e preservá-lo para as presentes e futuras gerações".

De acordo com ALMEIDA et al. (1993) existem duas principais vertentes nos planejamentos. A primeira, chamada de demanda, estuda a questões de ordem econômica e social da população definindo os objetivos a alcançar e a segunda, denominada de oferta, examina as características do meio em que se desenvolve a atividade humana, definindo as possibilidades atuais e potencial de atender as demandas. Tais autores ressaltam que o planejamento ambiental não possui uma definição precisa, pois se confunde com outros tipos de planejamentos (territorial, setorial) acrescidos da palavra ambiental. Mesmo assim, consideram que o planejamento ambiental consiste num conjunto de metodologias e procedimentos para avaliar as conseqüências ambientais de uma demanda e as oposições entre aptidões e usos dos territórios a serem planejados para oferta, identificando possíveis alternativas a esta ação.

De acordo com BLOWERS (1996) o planejamento ambiental procura alcançar as metas do desenvolvimento sustentável por meio de um sistema de coordenação e controle, organizado através de processos democráticos e participativos do governo em todas as suas esferas. Possui uma abordagem 
abrangente do manejo ambiental com três características elementares: 1) considera a incerteza futura por uma abordagem preventiva; 2) reflete a natureza integrada dos processos ambientais e políticos e 3) proporciona uma visão estratégica para tomada de decisão.

Segundo BALLESTER et al. (1995), a complexidade ambiental exige o conhecimento minucioso das variações espaço-temporais dos fatores naturais e antrópicos que atuam sobre o mesmo. O casamento de tais dimensões, permitindo o processamento concomitante dos dados, tem sido possibilitada pelos Sistemas de Informações Geográficas, definidos de maneira genérica, como tecnologias para investigação dos fenômenos ambientais combinando os avanços tecnológicos da cartografia e dos bancos de dados automatizados, o sensoriamento remoto e a modelagem de sistemas. As informações de caráter sinergético, resultantes do emprego destas ferramentas, têm auxiliado proposições mais acertivas para o manejo ambiental. Em apoio a uma abordagem integrada do processo de tomada de decisões se faz necessário o uso de dados e informações de forma sistemática e simultânea de dados sociais, econômicos e ambientais.

Conforme GARCÍA-HUIDOBRO (1998) o processo de desenvolvimento sustentável demanda, paralelamente, exigências nos meios físico, biológico e socioeconômico. No meio físico-biolótico é indispensável à conservação dos recursos naturais para otimizar o aproveitamento dos ecossistemas; a realização de processos produtivos sustentáveis; a obtenção de produtos sem contaminação e o progressivo melhoramento de habitats e das paisagens. No meio socioeconômico, requer que os ecossistemas garantam o trabalho, entradas competitivas com demais setores produtivos e, de maneira geral, a qualidade de vida compatível com suas necessidades e limitações atuais. No campo econômico o enfoque sustentável exige rentabilidade da atividade, qualidade dos produtos segundo demandas de mercado e continuidade do negócio para um horizonte de longo prazo.

No Brasil, com a promulgação da Lei 6.938/81, estabeleceu-se que a implantação de empreendimentos de infraestrutura tipificados na citada Lei deve ser precedida de um estudo de seus possíveis impactos sobre o meio ambiente de 
forma integrada. Entendendo-se por meio ambiente o Meio Físico (estrutura abiótica: clima, topografia, pedologia, regime e distribuição dos corpos d’ água, etc.), Meio Biológico (estrutura biótica: organismos vivos e suas relações), e Meio antrópico (atividades humanas e aspectos que incluem variáveis sociais, culturais e econômicas).

Nesse sentido, pensando o planejamento ambiental como uma análise integrada do meio ambiente, o planejador jamais deve esquecer que as peças mais importantes envolvidas neste processo são a sociedade, a natureza e a dinâmica de influência mútua na interação de ambos. A sociedade, ao utilizar um ecossistema, qualquer que seja ele, altera sua estrutura e funcionamento, causando impactos que podem ser irreversíveis. Todavia, isso pode ser evitado ou minimizado, por intermédio do conhecimento e planejamento prévio do uso desse ecossistema. $\mathrm{O}$ planejamento deve ser capaz de produzir e definir normas de uso e ocupação da terra, além de estabelecer diretrizes claras para o desenvolvimento sustentável e conservação do meio ambiente, sugerindo alternativas para reverter o processo de deterioração ambiental, social e econômica.

Portanto, a manutenção, a renovação de recursos e a recuperação ambiental e social são os grandes desafios da humanidade para o século que se inicia, buscando o equilíbrio entre os fatores de produção, extração de recursos e manutenção do meio ambiente.

\subsection{Zoneamento Ambiental}

Segundo CADAVID GARCÍA (1991), o zoneamento vai além de identificar, localizar, e classificar atributos de um território. Pode ser compreendido, também, como o resultado de análises dinâmicas e regionalização de atributos relevantes alcançando, conseqüentemente, a integração dessas

análises. É um trabalho multidisciplinar, balanceado, quantitativo, a ser desenvolvido com foco analítico e sistêmico, orientando a revisão e/ou elaboração de políticas de pesquisa e conservação e manejo integrado de recursos naturais. 
O foco analítico diz respeito à regionalização e diagnósticos dos atributos mais importantes, ou seja, com o qual os estudos desenvolvidos pelas equipes multidisciplinares, envolvendo os diferentes fatores ambientais, dariam sua maior contribuição; ao mesmo tempo o foco sistêmico refere-se a integração dos diagnósticos, prognósticos e síntese para cada conjunto de informações.

O zoneamento, independente de sua adjetivação, define as zonas "homogêneas" dentro de um recorte espacial, segundo critérios de agrupamentos pré-estabelecidos, cujos resultados podem ser demonstrados através de mapas temáticos, matrizes ou índices técnicos.

Para ROSS (2006) o zoneamento ambiental é um processo integrador das disciplinas técnico-científicas, uma vez que considera as potencialidades do meio, procurando estabelecer uma relação de harmonia entre a sociedade e a natureza, baseado no ordenamento territorial e no desenvolvimento atrelado à política conservacionista.

DEL PRETTE E MATTEO (2006), definiem sucintamente o termo zoneamento, descrevendo-o como ferramenta de ação utilizada por agentes privados e pelo poder público desde a formação das sociedades, com o objetivo de distribuir as atividades humanas de maneira organizada no espaço.

De acordo com SOUZA (2009) e MONTAÑO et al. (2005), o zoneamento ambiental desempenha o papel de um diagnóstico no que concerne aos recursos naturais, aspectos socioeconômicos e jurídico-institucionais, buscando apontar potencialidades, fragilidades e a capacidade de suporte do meio.

LIMA (2006) sustenta que as definições de zoneamento praticadas no Brasil em sua legislação têm relação com o conceito de zoning e land use planning dos Estados Unidos, no sentido de que zoning nos dá a noção de controle do uso das propriedades particulares, intervindo no direito de propriedade assim como o zoneamento urbano no Brasil, enquanto o land use planning utiliza uma abordagem menos restrita de planejamento, sem imposição de usos. 
Dessa maneira, são instrumentos complementares, embora regulamentados por legislação distinta. São objetivos do land use planning (comprehensive planning) identificar as possibilidades de uso, a capacidade de suporte, as demandas sociais, os impactos ambientais de certas atividades, as dinâmicas atuais de uso do território e as tendências e cenários futuros. Por seu turno, cabe ao zoneamento "estrito senso" (zoning ordinances) estabelecer as obrigações de uso e de ocupação, os limites de construção, os tipos de usos adequados, industrial, agrícola, residencial, distanciamento entre as construções, densidade da ocupação, preferencialmente subsidiado pelo land use planning (LIMA, 2006).

SOUZA (2009) e RANIERI et al. (2005) comentam que são encontradas diferenças quanto aos recortes territoriais considerados, às escalas, legendas, métodos, objetivos, entre outros fatores observando os produtos de zoneamentos ambientais ou com denominações outras (zoneamento ecológico-econômico, somente ecológico, geoambiental, entre outros) realizados no Brasil nas últimas décadas, conforme o perfil dos profissionais ou instituições envolvidos em sua elaboração. O ponto convergente identificado para estes trabalhos é a busca pela incorporação de aspectos ambientais na divisão do território em zonas.

GANDRA (2008), com base no que diz Xavier da Silva, salienta que:

O zoneamento ambiental pode ser considerado como a definição de setores ou zonas com objetivos de manejo e normas específicas, com o propósito de proporcionar os meios e as condições para que o desenvolvimento e atividades econômicas de uma região possam existir de forma eficaz e em harmonia com a conservação da natureza e dos recursos naturais. O processo de zoneamento pode ser definido como a fragmentação controlada e ordenada de um território, segundo critérios discriminados.

Segundo MILLIKAN E DEL PRETTE (2000), os zoneamentos executados no Brasil estão atrelados a duas correntes, sendo uma delas relativa à regulação do uso do solo urbano e a outra ao zoneamento agrícola. A primeira corrente está ligada à preocupação com a saúde humana, definindo zonas para as diversas atividades, de forma a preservar as áreas residenciais distantes de possíveis incômodos e perturbações. Esta corrente de zoneamento dá vida à "Lei de Zoneamento" de caráter essencialmente normativo. Já a segunda corrente, a do "zoneamento agrícola", tem por objetivo indicar aptidões de acordo com as 
multiplas atividades produtivas do meio rural, não propondo regras de uso do solo, mas contribuindo na tomada de decisão, tanto para o produtor rural quanto para as políticas de financiamento de atividades agrícolas (RANIERI et al. 2005).

MILLIKAN E DEL PRETTE (2000), seguindo seu raciocínio sobre as correntes de zoneamento no Brasil, acrescentam que o zoneamento ambiental surgiu representando o que seria uma terceira corrente, apresentando caráter normativo, restritivo e tendo por finalidade proteger o meio ambiente.

SILVA E SANTOS (2004) colocam que os zoneamentos sob as diversas adjetivações que possam receber convergem em seu resultado, que é a delimitação de zonas, mesmo que por diretrizes metodológicas distintas, variando conforme o objetivo ou o objeto.

De acordo com BRASIL (1984), o zoneamento geoambiental é a setorização do espaço geográfico, conforme as suas potencialidades, restrições e problemas, estimando- se os limites para sua exploração racional, tendo em vista a conservação do meio ambiente.

Com base em PIVELLO et al. (1998) o zoneamento ecológico é entendido como a definição de unidades homogêneas de paisagem baseado em alguns aspectos físicos, biológicos e institucionais seguido do estabelecimento de níveis de fragilidade ambiental em cada uma das unidades.

O zoneamento agrícola busca responder quando, onde e quais culturas plantar, considerando as demandas bioclimáticas da planta baseando-se em características pedológicas, geomorfológicas e nas condições climáticas, como por exemplo, a disponibilidade hídrica, faixas de temperatura adequada, etc. De acordo com ROSSETI (2001) tal planejamento visa o "desenvolvimento de estudos de regionalização dos sinistros climáticos no Brasil, visando minimizar as perdas na produção agrícola, disponibilizando ao produtor rural, técnicas que permitam fugir de riscos climáticos oriundos do regime de chuva”. 
Para o zoneamento agropedoclimático (CHAGAS et al. 2001) salienta-se a abordagem integrada entre os aspectos climáticos e pedológicos, além de considerar áreas importantes sob as óticas ecológica e paisagística para manutenção da biodiversidade.

Verificam-se, ainda, o zoneamento climático para definição de zonas em função de aspectos climáticos; o zoneamento edafoclimático por culturas, que estabelece zonas de plantio para determinadas culturas; o zoneamento para locação de empreendimentos, elaborado em estudos de viabilidade técnica, econômica e ambiental de empreedimentos tais como: gasodutos, aterro sanitários, indústrias, ferrovias, entre outros (GRIFFITH, 1989; SOUZA, 1990; RANIERI, 2000).

Finalmente, o zoneamento urbano, definido por legislação de uso e ocupação do solo urbano municipal. Estabelece normas para as formas de uso e tipos de construções da área urbana, estabelecendo limitações e aptidões em cada zona.

Portanto, o zoneamento não deve ser olhado apenas como um instrumento de restrição, mas sim de regulação social do uso dos recursos naturais. Para tanto, precisa ser encarado como um modelo de gestão territorial, baseado na disponibilidade e transparência de informações e na negociação social das metas de regulação de apropriação e uso do território.

Assim, o zoneamento ambiental é um instrumento político e técnico de planejamento, cuja finalidade é otimizar o uso do espaço. Tal otimização é conseguida pelas vantagens oferecidas por ele:

- Ser um instrumento técnico de informação sobre o território, necessária para planejar a sua ocupação racional e o uso sustentável dos recursos naturais;

- Prover uma informação integrada em uma base geográfica; 
- Classificar o território segundo suas potencialidades e vulnerabilidades;

- Ser um instrumento político de regulação do uso do território;

- Permitir integrar as políticas públicas em uma base geográfica, descartando o convencional tratamento setorializado de modo a aumentar a eficácia das decisões políticas;

- Permitir acelerar o tempo de execução e ampliar a escala de abrangência das ações;

- Produzir informações para o processo de tomada de decisão para ordenamento do território que auxiliam a compreensão do cenário atual e, conseqüentemente, favorecem a negociação entre as várias esferas de governo e entre estas, o setor privado e a sociedade civil, sendo assim um instrumento para a construção de parcerias; e

- Ser um instrumento do planejamento e da gestão para o desenvolvimento regional sustentável (BECKER \& EGLER, 1997).

Apesar do conceito de Zoneamento Ambiental estar intimamente associado ao Plajejamento Ambiental e territorial por parte do poder público, essa metodologia pode ser apropriada ao planejamento de projetos de infraestrutura desenvolvidos pelo setor produtivo. Assim, para que o efetivo planejamento seja possível, é necessário conhecer os recursos disponíveis em relação a sua quantidade e qualidade, bem como os objetivos a que se destinam seus usos. Neste sentido, a utilização do zoneamento como avaliador do território é comum, visto que é considerado um integrador de informações ambientais (SILVA; SANTOS, 2004). 


\subsection{Geotecnologias}

Toda a tentativa humana de representar a realidade envolve a geração de conceitos. O espaço geográfico, sendo contínuo e complexo, requer, para sua representação, conceitualizações que se operacionalizam através de procedimentos de abstração, generalização e aproximações (GOODCHILD et al., 1992). Considerando-se que este trabalho lança mão de conceitos atrelados às geotecnologias, é importante a definição de alguns desses conceitos utilizados no estudo ora proposto.

No Brasil as tecnologias que permitem automatizar a análise espacial são conhecidas como: Geomática, Geoprocessamento, Sistema de Informação Geográfica e mais recentemente Geotecnologias. Embora cada termo apresente um conceito diferente, abordam mais ou menos a mesma temática. Estes conceitos são bastante discutidos nas obras de TOMLIN (1990), MAGUIRE et al. (1993 e 1997), CÂMARA et al. (1996), BURROUGH \& MCDONNELL (1998), XAVIER DA SILVA e ZAIDAN (2004), TOMLINSON (2005) e DEMERS (2009).

As geotecnologias possuem papel relevante na gestão ambiental por tornar o gerenciamento de dados espaciais mais didático e intuitivo, além de permitir diferentes tipos de análises, aumentando o poder crítico na tomada de decisões. Elas podem ser entendidas como uma tecnologia que integra informações contidas em um plano de informações espaciais ou georreferenciado. Seu tratamento e manipulação abrem um leque para a elaboração de mapas temáticos e análises mais ou menos simples, que estabelecem correlações entre a representação espacial e as informações disponíveis.

As geotecnologias abarcam, dentre outras, ferramentas como o Sistema de Informações Geográficas. Neste estudo, serão trabalhadas ainda, mais duas ferramentas que estão intrinsicamente conectadas ao SIG e serão relevantes ao trabalho: Banco de Dados e Análise Espacial. 


\subsubsection{Sistema de Informação Geográfica - SIG}

O termo Sistema de Informação Geográfica (SIG) é utilizado para sistemas que executam tratamento digital de dados geográficos. Tal sistema contempla os atributos dos dados e sua geometria na superfície terrestre e representados dentro de determinados atributos cartográficos (sistemas de coordenadas, projeção, datum). As principais características de um SIG são: associar dados espaciais dentro de uma base de dados uniforme, oferecendo ferramentas para o tratamento e visualização destes dados.

Conforme RODRIGUES (1993), o sistema de informações geográficas pode ser compreendido por um "conjunto de tecnologias de coleta, tratamento, manipulação e apresentação de informação espacial". O conhecimento do espaço ou do território não é simplesmente a sobreposição de dados, em um dado momento, mas sim a integração destes dados inseridos na mesma unidade de análise. Permite singularizar cada espaço através de seus atributos para que se possa atuar com mais segurança, além de discernir e jogar luz aos fenômenos que nele ocorrem, apoiado em análises mais criteriosas, diminuindo interferências (ZAIDAN \& XAVIER-DA-SILVA, 2007).

O Sistema de Informação Geográfica (SIG) têm-se tornado, nas ultimas décadas, uma ferramenta valiosa nas mais diversas áreas do saber. Tais sistemas constituem um ambiente tecnológico e organizacional que tem, cada vez mais, ganho adeptos no mundo todo não só para as análises geográficas, como as demais ciências, a exemplo, da Medicina, Geologia, Pedologia, Biologia (ecologia), etc, caracterizado como uma ferramenta Multidisciplinar (COELHO, 2007).

Segundo NEGREIROS (2003) com a popularização das técnicas de geoprocessamento e dos SIG, o tratamento digital das informações topográficas foi viabilizado.

De acordo com SILVA (1999), o uso de Sistema de Informações Geográfica (SIG) na tomada de decisão é uma ferramenta eficiente em diversas áreas do 
conhecimento, uma vez que permite ao processo de tomada de decisão seu desenvolvido de forma mais fundamentada.

No Sistema de Informação Geográfica (SIG), as camadas temáticas são selecionadas e através de cruzamentos de dados, geram novas informações, que poderão servir de base para o planejamento e recomendações de uso e manejo do espaço.

Segundo SILVA et al. (1999), são três modos fundamentais de utilização de SIGs:

- Ferramenta para produção de mapas;

- Suporte para análise espacial de fenômenos;

- Banco de dados geográficos, com funções de armazenamento e recuperação de informação espacial.

Desta forma, Segundo MAZUR (2013) um SIG pode ser definido, como um conjunto de equipamentos e programas de computador que possibilitam a entrada e a edição, o armazenamento, o questionamento e o acesso de informações, sua transformação, análise, demonstração e impressão de informações espaciais, e sua espacialização (localizadas por meio de coordenadas geográficas em relação a algum sistema de referência). Assim o SIG é uma tecnologia relacional que permite a integração de cada elemento do ambiente à sua posição no espaço e às suas respectivas informações topológicas.

Nos dias de hoje, o termo "SIG" é conceituado como um método computacional de sobreposição e combinação de variados tipos de dados com referência espacial na forma de mapa ou de carta geográfica, para a elaboração de informações. Os dados são dispostos em camadas ou planos de informação, que por sua vez encarnam a distribuição espacial dos recursos em um momento definido, referenciado por coordenadas geográficas. MAZUR (2013) sugere que a diferença entre "dado" e "informação" se dá porque o primeiro corresponde a um conjunto de valores alfanuméricos sem estrutura lógica explicativa por si só; já a 
informação seria um conjunto de dados estruturados de forma a possuir um determinado significado para aplicação particular. Dessa forma, a informação também pode agregar o componente da subjetividade.

MENESES (2003) divide a evolução do SIG em três momentos: manipulação e visualização de banco de dados (primeira fase), operações analíticas de dados não gráficos e estrutura organizacionais (segunda fase) e análise espacial (terceira fase).

Com início na década de 50, a primeira fase é caracterizada pela necessidade de armazenar, organizar, processar e visualizar dados. Isto deu origem às versões primordiais de SIG, focadas na manipulação e visualização de dados.

A segunda fase foi marcada pelo crescimento da capacidade de processamento e de memória dos computadores possibilitando novas concepções e a difusão do SIG, conforme MENESES (2003). Sob essa ótica, as operações analíticas são evidenciadas através de modelos matemáticos com dados numéricos não gráficos.

Durante a década de 80 , a terceira fase é caracterizada pela diminuição de recursos para a pesquisa científica em oposição ao crescimento do setor industrial e comercial do SIG. Neste momento, o potencial do SIG foi mais utilizado, combinando atributos não geográficos com as relações topológicas dos objetos geográficos para realizar análises espaciais sobre dados georeferenciados (MENESES, 2003).

Conforme MELLO (2011), nos anos 80 a tecnologia do SIG começa um processo de desenvolvimento que se extende até os dias atuais. A incorporação de diversas funções de análise espacial propiciou novas aplicações para o SIG.

Usualmente diz-se que os SIGs são ferramentas de manipulação de objetos (feições geográficas) e seus atributos (banco de dados) por meio de 
relacionamento espacial (topologia). A seguir é apresentada a figura $1 \mathrm{com}$ a esquematização de um SIG:

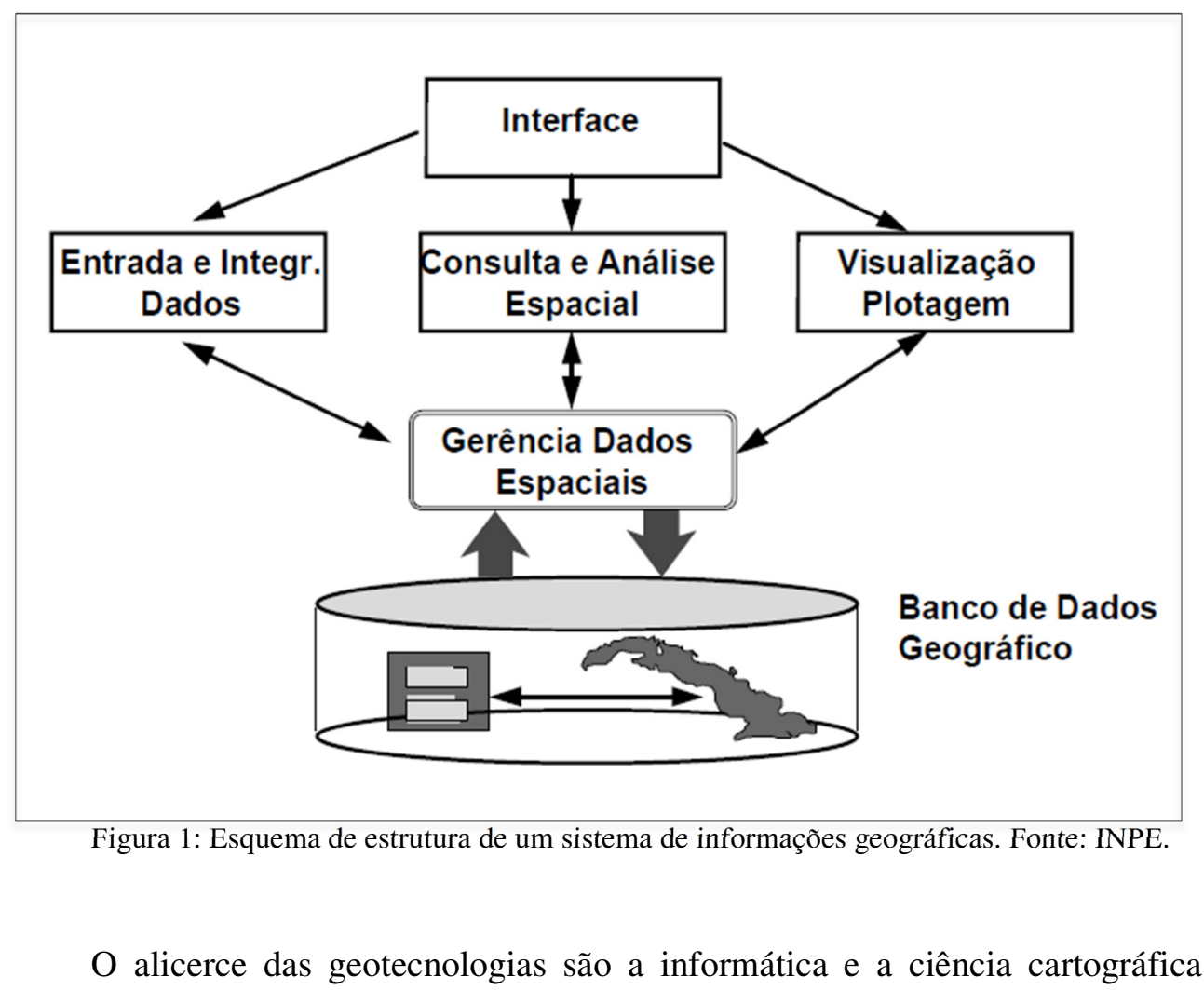

Contudo, as suas potencialidades de integração de informações geram subsídios para a tomada de decisão em múltiplas áreas do conhecimento científico.

Atualmente, um vasto crescimento da incorporação do SIG nas organizações é notado, pela diminuição dos custos das tecnologias de informação e, também, pelo aparecimento de alternativas tecnológicas menos onerosas para a construção de bases de dados geográficos.

\subsubsection{Banco de dados de SIG}

Segundo STRAUCH et al. (1998), os SIGs fornecem arquiteturas que possibilitam o gerenciamento dos dados geográficos. Tais modelos de dados propiciam a estratificação da informação geográfica em um conjunto de níveis denominados de planos (ou camadas) de informação (PIs) ou layers. Cada um destes níveis corresponde a uma mesma área atrelada a uma concepção singular 
da realidade da área. Esta concepção corresponde a um tema independente, como a vegetação, ao uso do solo, hidrografia, entre outros que possuem todo um banco de dados alfanuméricos associados a eles.

Ainda de acordo com STRAUCH et al. (1998), tais níveis podem ser diferenciados conforme sua finalidade na base de dados em:

1. Níveis de informação básica: fornecem uma representação monocromática, mas essencial, do espaço geográfico. Conjunto básico de feições geográficas que fornecem informações necessárias ao reconhecimento topográfico da região.

2. Níveis de informação temática ou especial: fornecem a representação policromática do espaço geográfico da área de aplicação da base de dados. Estes níveis armazenam as descrições dos temas necessários para o SIG atingir o objetivo proposto. Eles descrevem as ocorrências, distribuições e relações espaciais de entes e feições do contínuo espacial para cada tema.

A estruturação em níveis possibilita ao usuário combinar conceitos de modelagem de dados simples com o intuito de criar níveis de informação, gerando conjuntos de características que desempenham relações complexas do mundo real (STRAUCH et al., 1998).

De acordo com MAZUR (2013), o banco de dados consiste em uma coleção de dados inter-relacionados e um programa para prover o acesso a esses dados. $\mathrm{O}$ objetivo principal de um sistema de banco de dados é possibilitar um ambiente que seja adequado e eficiente para uso na recuperação e armazenamento de informações. De maneira geral, os dados trabalhados em um ambiente georreferenciado são diferenciados entre dados matriciais (ou raster) e dados vetoriais.

Os dados vetoriais são feições que correspondem geometricamente a pontos, linhas ou polígonos. Essas feições possibilitam a elaboração de correlações variadas que podem ser definidas entre os objetos, independente da base 
geocodificada, fundamentada nos seus atributos não espaciais, lançando mão de técnicas estatísticas executadas sobre os dados alfanuméricos do banco de dados. Os produtos dessas operações podem ser transportados para a base geocodificada do SIG e exibidos ou tratados de maneira analítica, tais como definição de proximidades e conexões.

Os dados matriciais são aqueles em formato de matriz, onde cada pixel contém informações correspondentes somente a este pixel. A estrutura dos dados, segundo planos de informação, pode ser compreendida por uma matriz Aijk, na qual i e j são coordenadas localizadoras no espaço, e a dimensão k é constituída por sucessivas camadas de informações ambientais, cada uma delas compondo a representação digital da variação geográfica das variáveis ambientais comtempladas no acervo de conhecimentos disponível no SIG (ZAIDAN \& XAVIER-DA-SILVA, 2007).

Na figura 2 a seguir é possível verificar um modelo de representação de um mesmo local do espaço a partir de dados vetoriais e matriciais.

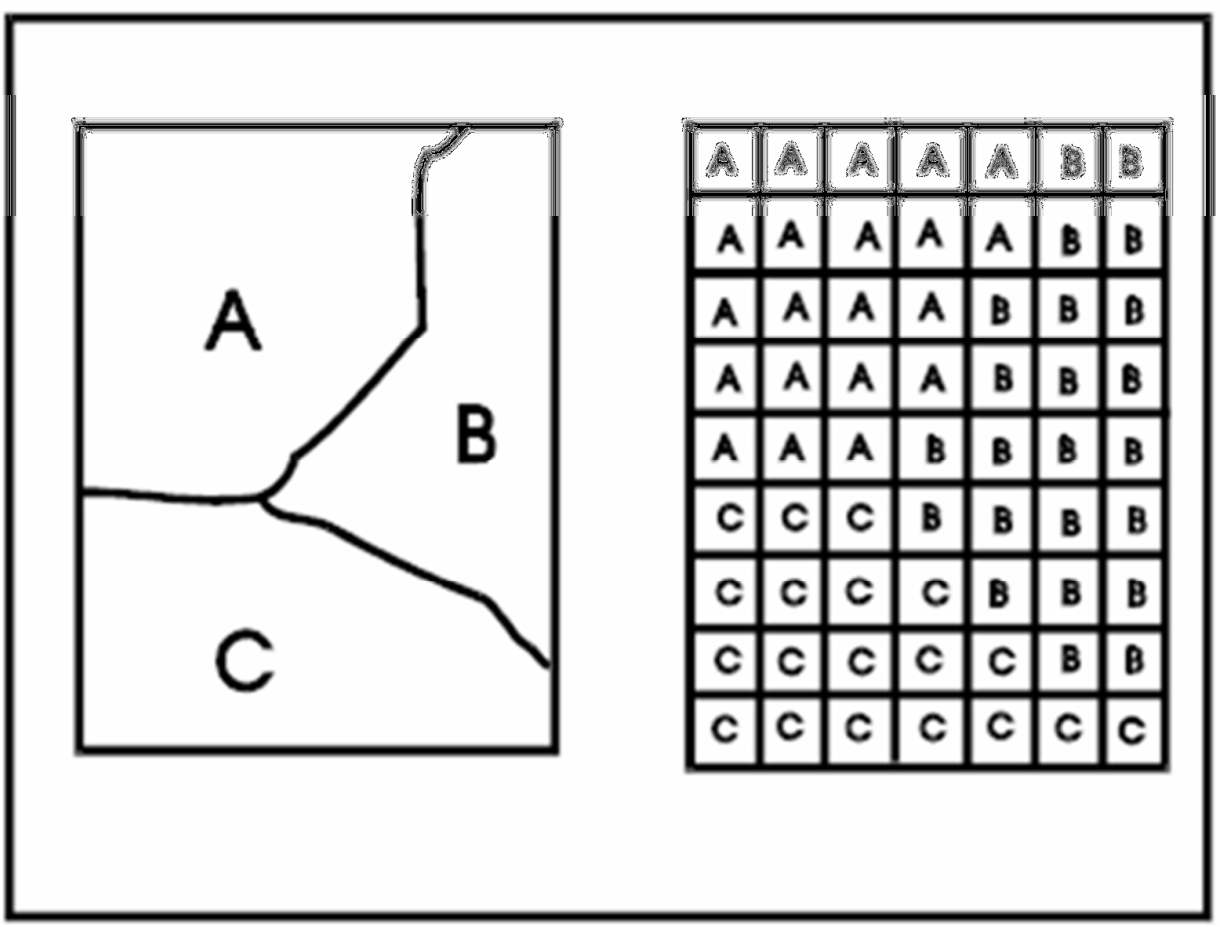

Figura 2: Dados raster e dados vetor. Fonte: INPE. 


\subsubsection{Análise Espacial em SIG}

A análise espacial realiza a conexão entre a cartografia e a análise aplicada, a estatística e a modelagem, facilitando a sobreposição de variáveis georreferenciadas e, a partir delas, gerar novas variáveis. A complexa realidade do espaço geográfico pode ser em um contexto de análise espacial, fragmentada nas suas componentes ou derivadas obtidas a partir de uma base informativa geral, o que vai de encontro com o princípio do exercício da análise em si. Assim, análise espacial, significa também extrapolação e criação de nova informação favorecendo uma compreensão melhor, tanto sob uma ótica isolada ou integrada.

ROCHA (2004) define a análise espacial como uma ferramenta que permite diversos tipos de manipulação dos dados espaciais de forma a extrair como produtos novos saberes. Tal produção é concebida através do uso de funções como: consulta de informações geográficas dentro dos recortes espaciais de interesse, manipulação de mapas e a produção de sumários estatísticos dessa informação. Além das análises básicas citadas, é possível ainda incorporar funções mais complexas como a investigação de padrões e relacionamentos dos dados, dentro de um recorte espacial pré-estabelecido, permitindo a compreensão de fenômenos e a previsão de seu comportamento.

A análise espacial para MENESES (2003) pode ser compreendida através de duas correntes, a estatística espacial, que trabalha apoiada em dois pilares principais: modelos matemáticos de distribuição e correlação, os quais agregam propriedades de significância e incerteza, produtos da dimensão espacial; e geocomputação, através de um tripé de técnicas, sendo seus pilares: as redes neurais, a busca heurística e os autômatos celulares. O foco da aplicação desse tripé é explorar bases de dados e gerar resultados empíricos (não exatos) com vastas aplicações práticas. Essa gama de instrumentos de análise espacial dão aos resultados das investigações sobre a realidade modelada, uma grande confiabilidade (CÂMARA, 2000).

O processo da análise espacial busca a escolha de um modelo de ilação que apresente, de maneira clara e objetiva, o relacionamento espacial atrelado ao 
fenômeno observado, por meio do encadeamento de procedimentos analíticos (CÂMARA et al., 2002). Os procedimentos preliminares da análise inserem o conjunto de métodos exploratórios gerais de análise e a visualização dos dados, comumente por via de mapas. Essas técnicas descrevem a distribuição das variáveis de estudo, identificam situações incomuns ou inesperadas, não só em relação ao tipo de distribuição, mas também em relação aos vizinhos. Desta feita, buscam a descoberta de padrões na distribuição espacial e assim tornam possível o estabelecimento de hipóteses sobre as observações, apontando o melhor modelo inferencial suportado pelos dados.

A noção de análise espacial num SIG para OLIVEIRA (1997), está baseada na idéia da associação de dados espaciais e de atributos alfanuméricos, traduzindo-se numa série de funções relacionadas com a seleção, pesquisa e modelagem de dados.

Para a realização da análise espacial em SIG, parte-se da premissa de que as relações espaciais entre as entidades geográficas são fundamentais. Assim o entendimento e domínio do conceito de topologia são fundamentais nos SIG, principalmente na análise espacial relacionada ao modelo de dados vetoriais espaciais. A topologia delimita as relações espaciais entre os elementos gráficos (pontos, linhas, linhas e áreas), ou seja, o posicionamento relativo de cada elemento gráfico entre si.

Ainda, dentro da gama de possibilidades analíticas com relação ao posicionamento geográfico de fenômenos, a Análise Multicritério é uma vertente metodológica que funciona através do cruzamento de variáveis, sendo amplamente aceita para aplicação em diversos setores. A análise multicritério parte da premissa do mapeamento de variáveis por camadas de informação e na atribuição de escala com pesos e valores de pertinência para cada uma dessas camadas com intuito de se compreender as dinâmicas que atuam no espaço (MOURA, 2007).

De acordo com BERTINI (2003b) as relações espaciais são vitais em aplicações geográficas e, por conseguinte em análises espaciais, sendo que o 
propósito da aplicação determinará a relevância de cada tipo de relação. As categorias de relações espaciais são agrupadas em:

- Topológicas: descrevem conceitos de vizinhança, incidência, sobreposição, não variando com a escala ou com a rotação, como por exemplo, disjunto, adjacente, dentro de.

- Métricas: consideradas em termos de distancias (como perto, longe) e direções (descrevem a orientação no espaço, como por exemplo, norte, sul etc.).

- De ordem (total ou parcial): são descritas por preposições do tipo em frente a, acima de, abaixo de etc.

De acordo com ARONOFF (1989), são quatro as categorias de funções consideradas para análise espacial em SIG:

- Funções de acesso ou pesquisa, classificação e medição - através deste conjunto de funções é possível ter acesso à informação gráfica e alfanumérica, possibilitando a realização de operações de Query-Display (pesquisa gráfica e pesquisa por atributos). Ao se efetuar um processo de análise espacial deste tipo só os atributos alfanuméricos podem ser criados e alterados.

- Funções de superposição de mapas (overlay) - este tipo de função de análise espacial constitui, em termos estruturais, um processo semelhante à manipulação de dados relacionais em tabelas e permite a realização de análises segundo uma aproximação da álgebra booleana ou da teoria dos conjuntos.

- Funções de análise de vizinhança - neste grupo as operações usualmente mais desenvolvidas são as de pesquisa, topográficas e de interpolação. A definição de funções de vizinhança envolve a análise das características da área envolvente a um local específico. Neste caso, é necessário definir o domínio de aplicação e o tipo de função a aplicar numa seqüência de análise específica. 
- Funções de análise de conectividade - estas funções são características da modelagem de dados matricial e caracterizam-se por permitir a descrição e a modelagem de processos de difusão e influência espacial. Também neste caso é necessário definir o domínio da aplicação deste tipo de função em relação à vizinhança de células, recorrendo à topologia implícita de uma estrutura em quadrícula. A definição e a simulação de processos de movimento, difusão e acumulação têm de ser explicitadas na realização de uma operação de análise espacial.

Para efetuar uma análise espacial, é essencial ter informação sobre a qual se deseja trabalhar. As observações diretas da realidade, formando uma coleção de fatos armazenáveis, são consideradas como dados. Dados processados transformam-se em informação. Podemos ilustrar os dados como um rol númérico e, considerar informação como significados atribuídos aos dados. A informação pode se apresentar de diversas maneiras e formas. Textos, números, gráficos ou imagens são considerados informação. Essa pode ser associada a uma localização geográfica. Denominam-se alfanuméricos os dados sob a forma de texto ou números, que podem estar organizados em forma de tabelas, podem referir-se a uma localização específica ou a um instante determinado (no tempo).

Denominam-se dados georreferenciados todos aqueles que possuem dimensão espacial e temporal, estando, via de regra, atrelados à localização na terra. Ainda de acordo com BERTINI (2003c) as entidades geográficas estão no espaço geográfico e são objetos que encontram correspondência no mundo real, com características espaciais e relacionamentos com outras entidades geográficas. Sintéticamente a representação espacial de um objeto georreferenciado é dada através de sua geometria vinculada à posição espacial.

São três os grupos de ilação ou inferência espacial: variação contínua, variação discreta e processos pontuais. A solução para uma questão relacionada à fenômenos com referência no espaço pode ser solucionada empregando-se o uso de um apenas um dos grupos ou ainda integração de alguns ou de todos. Abaixo, pode-se contemplar as definições de cada um deles: 
- Variação contínua: consideram um processo estocástico, cujos valores podem ser conhecidos em todos os pontos da área de estudo.

- Variação discreta: dizem respeito à distribuição de eventos cuja localização está associada a áreas delimitadas por polígonos.

- Processo pontual: é definido como um conjunto de pontos irregularmente distribuído em um terreno, cuja localização foi gerada por um mecanismo estocástico.

A partir do desenvolvimento e evolução das ferramentas SIG e de atributos mais complexos associados aos dados georreferenciados, veio a necessidade de quantificação da dependência espacial o que cuminou com o desenvolvimento das ferramentas de estatística espacial. De acordo com ANSELIN (1992), "a característica que distingue a análise estatística dos dados espaciais é que seu foco principal está em inquirir padrões espaciais de lugares e valores, a associação espacial entre eles e a variação sistemática do fenômeno por localização”. Assim o termo autocorrelação espacial é utilizado para distinguir-se da correlação estatística convencional. No caso da autocorrelação, empregam-se os valores de uma mesma variável, em duas posições diferentes para realização de cálculos estatísticos (ROCHA, 2004).

Existem diferentes métodos para se classificar os dados tornando-se necessário atender a determinadas regras para representar espacialmente estes valores. A distribuição em classes pode ser feita de forma manual ou automática, sendo quatro os principais métodos de classificação de acordo com MITCHELL (1999):

Limites naturais - identifica agrupamentos e padrões inerentes aos dados, de modo a que os valores dentro da mesma classe tendam a ser semelhantes e valores de classes diferentes tendam a ser diferentes. Os limites definem-se onde há rupturas entre grupos de valores. Este método é bom para se representar espacialmente valores de dados que não se distribuem equitativamente uma vez que coloca na mesma classe valores próximos, agrupando-os; 
Quantis - cada classe tem o mesmo número de elementos. Os elementos são ordenados de acordo com o valor do atributo, do menor para o maior, e vão se somando o número de elementos. Divide-se o total de elementos pelo número de classes que pré definidas para se obter o número de elementos que deve integrar cada classe. Posteriormente, atribui-se à primeira classe os primeiros elementos (de menor valor) até preencher a classe, após prossegue-se para a classe seguinte, preenchendo-a, e assim sucessivamente. Este método é útil para comparar áreas de dimensões semelhantes ou para representar espacialmente dados cujos valores se distribuem equitativamente.

Intervalos iguais - neste método cada classe tem uma amplitude igual em termos de valor, ou seja, a diferença entre o valor máximo e mínimo de cada classe é constante. Este método é mais apropriado na cartografia de dados contínuos, como a precipitação e a temperatura.

Desvio padrão - segundo este método, cada classe é definida pela distância do valor à média de todos os elementos. Calcula-se primeiramente a média e posteriormente o desvio padrão. Pode-se pensar neste método como sendo a variação de cada valor relativamente à média. Criam-se limites de classe acima e abaixo da média com base no número de desvios padrões que se determinar.

A decisão sobre o melhor método para se aplicar pressupõe que os dados e seus significados sejam conhecidos para dar coerência a escolha do método aplicado. A segunda etapa é a decisão da quantantidade de classes criadas. Os usuários de mapas de maneira geral podem identificar até sete cores numa carta ou mapa, porém o ideal é utilizar de quatro a cinco divisões, ou seja, usar mais do que sete classes e menos do que quatro, torna a leitura das mesmas uma tarefa difícil e pouco didática, dando brecha para que informações relevantes se percam na interpretação.

\subsubsection{Sobreposição de mapas (Map Overlay)}

De acordo com AHLQVIST (2009) um bom mapa oferece um quadro que é mais do que sua partes constituintes, quando demonstra, por exemplo, cidades 
representadas por pontos de diferentes tamanhos, ou estradas em variadas cores e espessuras.

Em vista da urgência em gerar respostas a algumas situações e de ter em mãos um produto didático como fonte que oriente o planejamento ambiental e gestão territorial, os mapas podem indicar, por meio de gradação de cores com tonalidades quentes e frias, informações como restrições ambientais ao uso e ocupação do solo, o risco a escorregamento de massas, a disponibilidade hídrica de uma bacia, entre outras.

Para a execução de mapeamento, as ferramentas em plataforma de SIG, oferecem uma rápida transição dos dados georreferenciados entre variados modelos, em multiplos formatos. O SIG também permite uma exibição visual eficaz como produto de mapeamentos, tornando a tomada de decisão mais rápida e intuitiva. Portanto a sobreposição de aspectos ambientais é de fácil interpretação não exigindo profundos conhecimentos técnicos acerca da questão ambiental ou de cartografia.

Dentre as ferramentas disponíveis de análise espacial em SIG a operação de map overlay é o procedimento base para a metodologia de sobreposição de aspectos ambientais. Este tipo de análise tem sido utilizado com grande frequência para resolução de questões geográficas, pois facilita a tomada de decisão por meio da interpretação do produto cartográfico (FAZAL, 2008). Tal análise é relatada em diversos trabalhos técnicos e acadêmicos, em âmbito nacional e internacional, demonstrando o uso deste procedimento em múltiplas áreas de aplicação, como: saúde, políticas públicas e meio ambiente (STOCKER \& BURKE, 2006; FOTHERINGHAM \& ROGERSON, 1994; CUTTER et al., 1997). Sua aplicação é mais comum na área ambiental, sendo que tal fato está relacionado à maior proximidade dessa disciplina com as geotecnologias. No Brasil, destacam-se os estudos de CREPANI et al. $(1996,2001)$ que constituem um marco para análise espacial. Esses autores aplicaram o método de overlay mapping para a geração do Zoneamento Ecológico Econômico com finalidade de ordenamento territorial na Amazônia Legal, posteriormente esse mesmo método foi aplicado às demais regiões do país. 
Esse aspecto analítico dos mapas iniciou a sistematização, dando um olhar aos problemas como um todo, com intenção de integrar especialidades científicas das ciências biológicas, sociais e naturais.

A operação de map overlay consiste na sobreposição de diversas camadas ou mapas, balizados, por exemplo, como um peso para cada variável, que ao final do processamento resultam em novo mapa ou camada contendo o resultado do cruzamento das variáveis.

Geralmente o processo de map overlay utiliza uma coletânea de informações indexadas espacialmente, que futuramente podem ser interpretadas, para responder questionamentos sobre fenômenos que se desenrolam no espaço. Desde operações simples de sobreposição de camadas, demonstrando onde processos correlacionados ocorrem, até sua forma mais avançada, através da análise de sobreposição de camadas expressando relacionamentos de processos, com variáveis temporais.

A primeira etapa da análise espacial diz respeito à definição do formato dos dados para trabalho, que pode ser feito tanto em formato raster (matriciais) como em vetores. A operação em dados raster é norteada por expressões aritméticas (soma, subtração, divisão e multiplicação), lógicas $(<,>, \leq, \geq \mathrm{e}=$ ) e booleanas (And, Or, Nor e Not). Em arquivos vetoriais, os operadores espaciais seguem lógicas de orientação e pertencimento $(\in, \notin, \subseteq \mathrm{e} \subseteq)$.

Os arquivos raster apresentam vantagens na duração e na facilidade de processamento sobre os arquivos vetoriais. Contudo, arquivos raster somente armazenam a informação do mapa final sob a forma do valor do pixel, não sendo possível atribuir a estes dados informações adicionais. Arquivos vetoriais, apesar da menor integração com as operações de sobreposição, tem como vantagem a possibilidade de se atribuir a cada polígono diversas informações sob a ótica das variáveis analisadas. Para melhor compreensão do método de Map Overlay, segue figura 3 ilustrativa: 


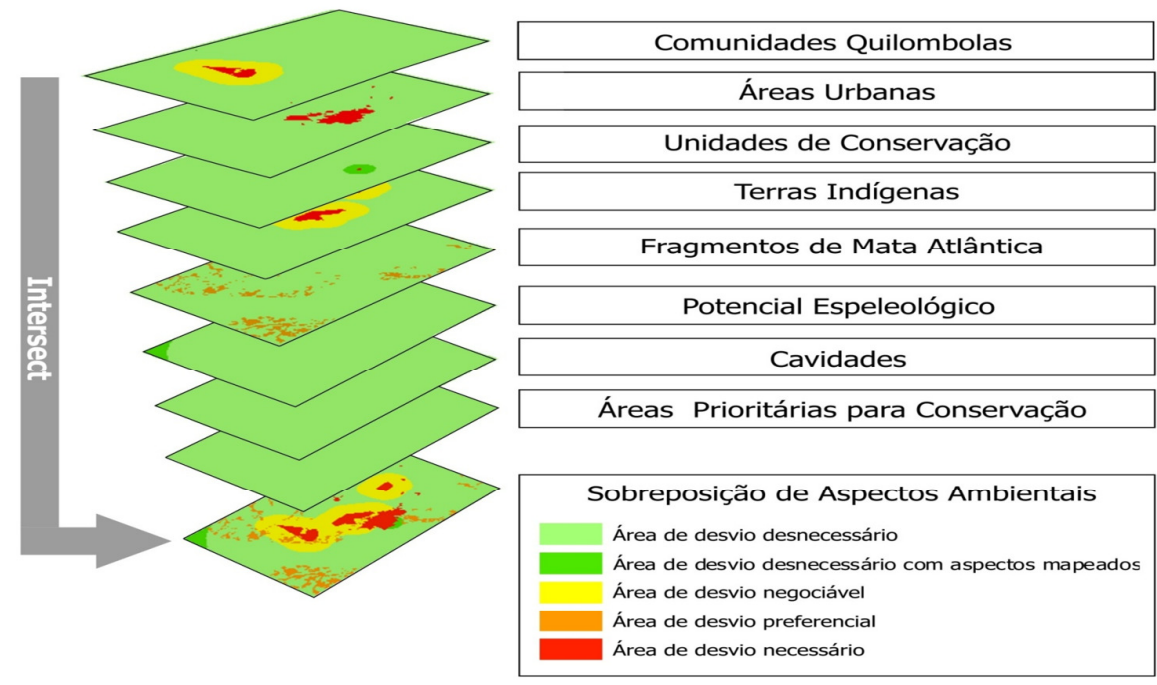

Figura 3: Esquema de map overlay. Fonte: ANTT

Uma vez definido o formato do dado a ser utilizado para composição de camadas do mapa, determinando sua geometria, escala e tamanho de pixel, partese para análises mais detalhadas de map overlay às quais AHLQVIST (2009) op. cit., divide em três categorias distintas: Overlay Descritivo, Overlay Dedutivo e Overlay Indutivo.

A modelagem de dados em plataforma SIG conforme exposto nos parágrafos anteriores tem sido de grande valia para a ordenação territorial e para a resolução de conflitos espaciais. No entanto, esta ferramenta só apresenta resultados satisfatórios se os dados inseridos na análise estiverem em escala condizente ao objeto de análise. Na confecção do Zoneamento Ecológico Econômico realizado por CREPANI et al. (1996) foram utilizados dados dos vários aspectos levantados pelo Projeto RADAMBRASIL (1970 a 1987). Esses dados foram mapeados em escala de 1:250.000, apesar da pequena escala, este documento constitui, até os dias de hoje, o mapeamento sistemático de recursos naturais de maior relevância, realizado no país.

Segundo RAIA (2000) o uso das ferramentas de um Sistema de Informação Geográfico é de fundamental importância em quase todas as etapas desenvolvidas em map overlay, pois permite manusear, alterar ou acrescentar outras informações, ou ainda trabalhar com parte dos dados com rapidez e flexibilidade. 
Como exemplo da aplicação de map overlay em meio ambiente e transportes, PEREIRA (2004) realizou uma análise de poluição atmosférica gerada pela emissão de gases e material particulado provenientes de tráfego veicular em certo trecho rodoviário. Para isso, lançou mão do uso de ferramentas SIG, associado a um modelo de previsão de poluição por material particulado baseado em dados de tráfego de veículos.

O modelo empregado para o cálculo da concentração de material particulado (fumaça) em função do volume de tráfego e da velocidade do vento foi desenvolvido por JOYCE et al. (1975).

No caso apresentado, pôde-se perceber que a associação de dados relacionados com o espaço geográfico possibilitou um diagnóstico sobre a questão ambiental em função da exposição da população conforme sua localização em relação à rodovia e o tráfego da mesma. 


\section{Estudo de caso - Viabilidade Socioambiental Legal para o traçado da linha ferroviária Nova Iguaçu (RJ) - Cariacica} (ES)

\subsection{Recorte espacial}

A via férrea Nova Iguaçu/RJ - Cariacica/ES, cujo seu traçado será avaliado e possivelmente readequado para reativação dessa ferrovia, possuiu aproximadamente $640 \mathrm{~km}$ de extensão em um alinhamento predominante nordeste-sudoeste, e se desenvolve transpondo a porção centro-sul do estado do Espírito Santo e o estado do Rio de Janeiro, da divisa ao norte com o estado capixaba, até sua porção centro-sul, terminando na região da baixada fluminense, junto à capital fluminense.

O empreendimento está inserido no Bioma Mata Atântica, que segundo o Instituto Brasileiro de Florestas, ocupa uma área de $1.110 .182 \mathrm{Km}^{2}$ e corresponde 13,04\% do território nacional. A Mata Atlântica é uma floresta pluvial tropical de clima quente e úmido que apresenta uma grande diversidade da biota e alto número de espécies endêmicas. Atualmente este bioma encontra-se ameaçado devido a sua fragmentação, apesar desse fato, estima-se que existam cerca de 20.000 espécies vegetais (cerca de 35\% das espécies existentes no Brasil), de acordo com o Ministério do Meio Ambiente.

Segundo dados do Instituto Nacional de Pesquisas Espaciais (2013) 11\% do estado do Espiríto e $18 \%$ do estado do Rio de Janeiro estão cobertos pelo Bioma Mata Atlântica.

Na região de inserção do empreendimento são poucos os remanescentes de Mata Atlântica, devido à densidade populacional e à intensidade da atividade econômica. 
Ao longo de seu trajeto, o traçado atravessa áreas de doze municípios no estado do Espírito Santo, e outros vinte e três municípios no estado do Rio de Janeiro, totalizando trinta e cinco municípios.

O mapa apresentado na figura 4 seguir ilustra a localização da via ferroviária Nova Iguaçu/RJ - Cariacica/ES existente hoje.

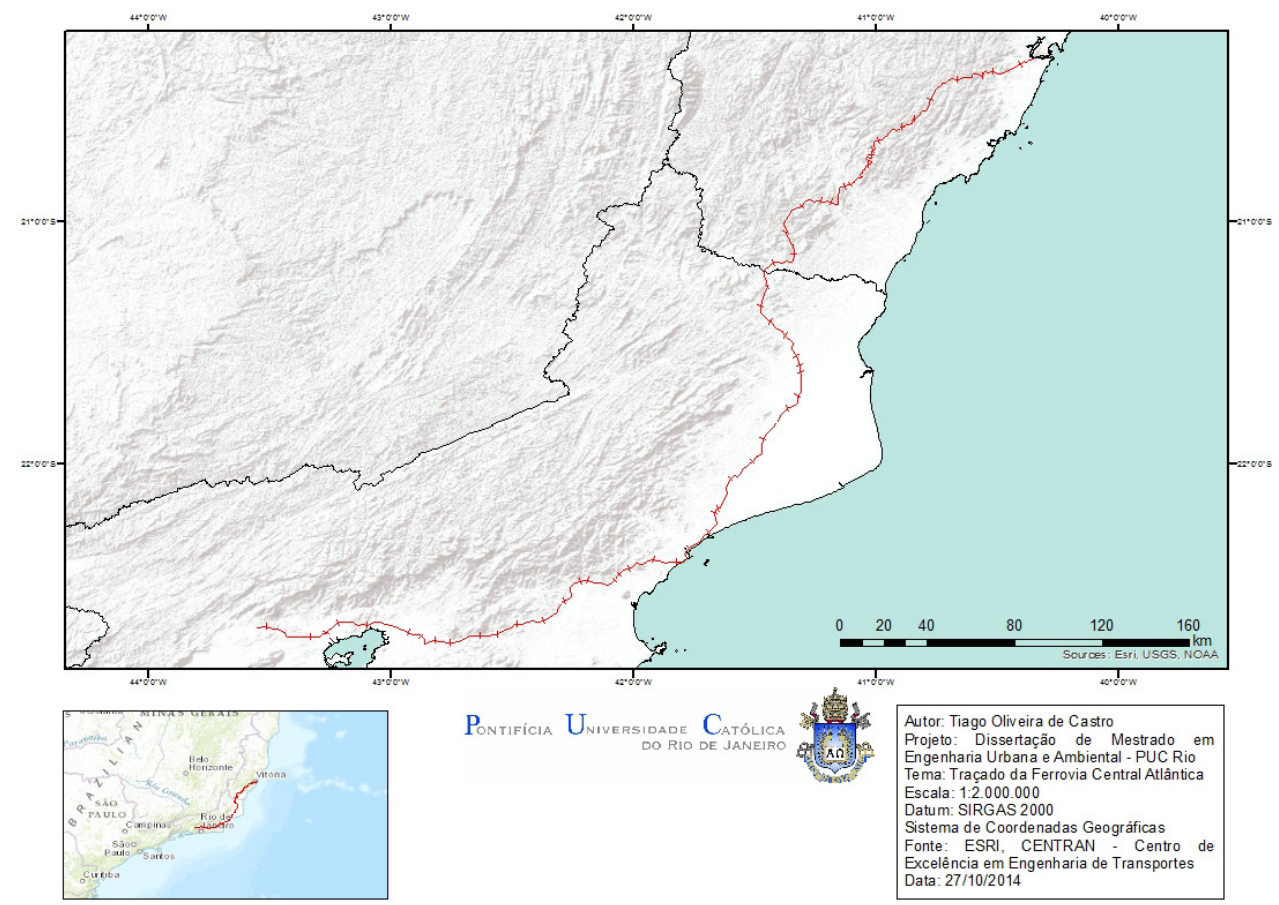

Figura 4: Mapa de situação da ferrovia Nova Iguaçu (RJ) - Vila Velha (ES). Fonte: própria

\subsection{Materiais}

Os dados elencados para levantamento e busca em órgãos oficiais são aqueles indicados na legislação ambiental, conforme definido na fundamentação do presente estudo. Também, não considerou-se elaborar novos dados para compor o estudo ora realizado, como declividade a partir das curvas de nível, por exemplo. A excessão ficou por conta das zonas de amortecimento de áreas protegidas, como as Comunidades Quilombolas, as Terras Indígenas e as Unidades de Conservação, uma vez que foram gerados buffers a partir de seus limites. A justificativa para a elaboração dessas zonas de amortecimento é sua importância como restrição legal e por não representarem novos dados, mas sim um complemento a alguns dados existentes. 
Os dados coletados e utilizados seguem a seguir, na tabela 1:

Tabela 1: Dados socioambientais legais obtidos em fontes oficiais. Fonte: própria

\begin{tabular}{|c|c|c|c|c|}
\hline $\begin{array}{l}\text { Dados socioambientais } \\
\text { legais obtidos em bases } \\
\text { públicas oficiais }\end{array}$ & Origem & Data & Datum & Escala \\
\hline Cavidades Naturais & & & WGS & \\
\hline Potencial Espeleológico & CECAV & 2004 & 84 & $1: 2.500 .000$ \\
\hline $\begin{array}{l}\text { Unidades de } \\
\text { Conservação }\end{array}$ & \multirow{3}{*}{ MMA } & & \multirow[b]{2}{*}{$\begin{array}{l}\text { SAD } \\
69\end{array}$} & \multirow[b]{2}{*}{$\begin{array}{l}1: 5.000 \mathrm{a} \\
1: 100.000\end{array}$} \\
\hline $\begin{array}{l}\text { Zona de } \\
\text { Amortecimento de } \\
\text { Unidades de } \\
\text { Conservação - Uso } \\
\text { Integral }\end{array}$ & & 2012 & & \\
\hline $\begin{array}{l}\text { Áreas Prioritárias para } \\
\text { Conservação da } \\
\text { Biodiversidade }\end{array}$ & & 2006 & $\begin{array}{l}\text { SAD } \\
69\end{array}$ & $1: 250.000$ \\
\hline $\begin{array}{l}\text { Comunidades } \\
\text { Quilombolas }\end{array}$ & \multirow[b]{2}{*}{ INCRA } & N/D & N/D & N/D \\
\hline $\begin{array}{l}\text { Zona de } \\
\text { Amortecimento de } \\
\text { Comunidades } \\
\text { Quilombolas }\end{array}$ & & N/D & N/D & N/D \\
\hline Terras Indígenas & \multirow[b]{2}{*}{ FUNAI } & $\mathrm{N} / \mathrm{D}$ & N/D & N/D \\
\hline $\begin{array}{l}\text { Zona de } \\
\text { Amortecimento de } \\
\text { Terras Indígenas }\end{array}$ & & N/D & N/D & N/D \\
\hline $\begin{array}{l}\text { Uso e Cobertura do } \\
\text { Solo }\end{array}$ & PROBIO & 2002 & $\begin{array}{c}\text { SAD } \\
69\end{array}$ & $1: 250.000$ \\
\hline
\end{tabular}

\subsection{Processamentos}

Como visto nos capítulos anteriores, o planejamento ambiental com foco no uso do território pode ser executado através do auxílio de técnicas de mapeamento, identificando restrições, traduzindo-as em mapas temáticos. Contudo, a simples sobreposição dos aspectos identificados como restritivos quanto ao uso e ocupação do solo pode não representar, de maneira eficiente, a realidade. Na figura 5, pode-se apreciar um mapa composto por todos os temas identificados e sobrepostos, no intuito de ilustrar tal afirmação. 


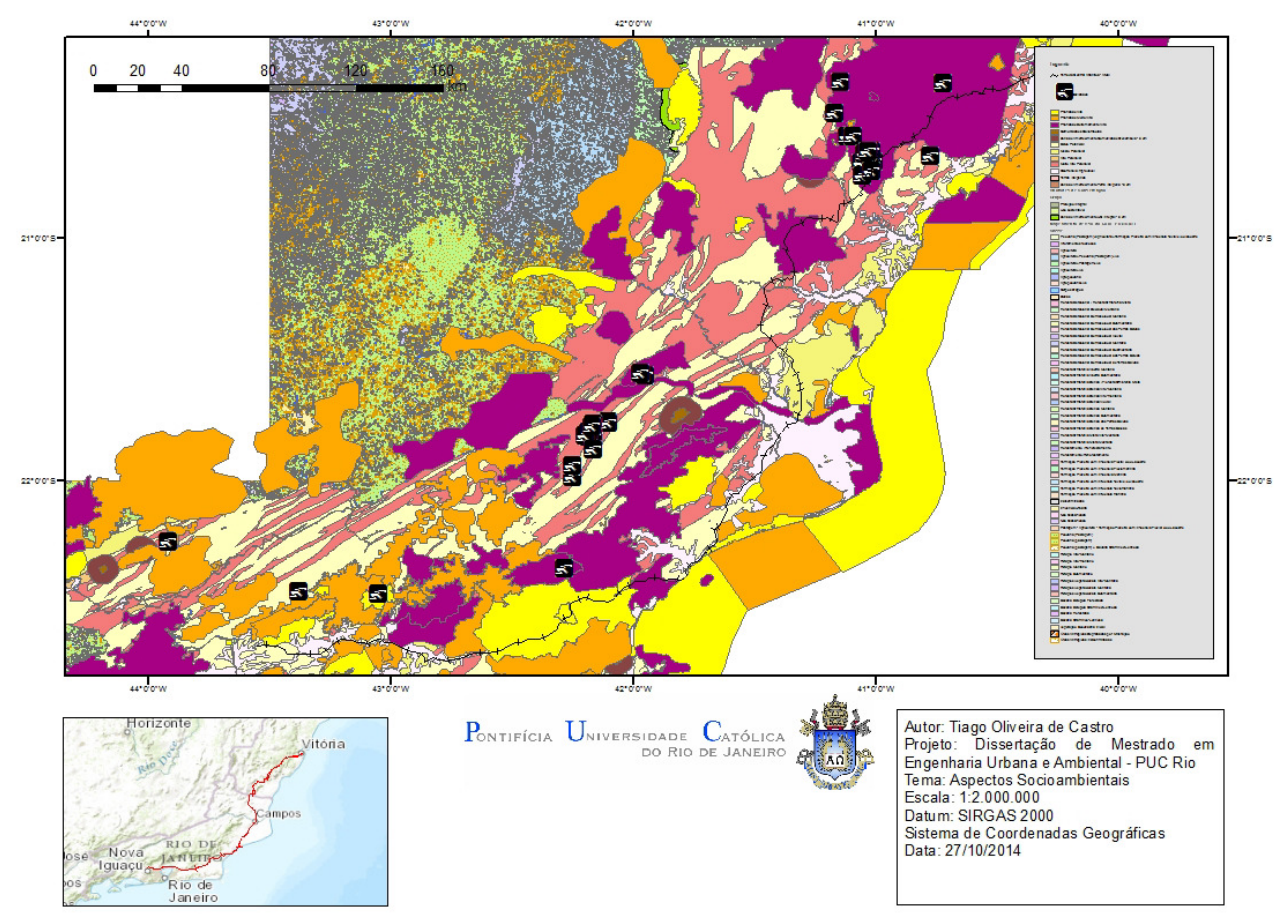

Figura 5: Mapa síntese das restrições socioambientais legais identificadas em órgãos oficiais. Fonte: própria.

Dessa maneira, é necessário que se desenvolva uma estratégia mais didática e simples na forma de demonstrar por via de mapa as restrições socioambientais legais sintetizadas.

Para alcançar tal resultado, é proposto um zoneamento ambiental que demonstre claramente e de maneira fiel à realidade, áreas mais ou menos propícias a realização de empreendimentos e uso e ocupação do solo. Assim, serão discutidas propostas de sintetização de dados, para se traduzirem em informação espacial, por meio de um mapa de categorias de restrições socioambientais legais.

\subsubsection{Pré-processamentos aplicados aos dados socioambientais legais oriundos de bases públicas em formato vetorial}

A proposta do estudo ora apresentado foi realizar o zoneamento das restrições socioambientais legais utilizando como dados de entrada arquivos vetoriais, com geometrias predominantemente poligonais e minoritariamente pontuais. A partir da representação vetorial dos aspectos socioambientais legais identificados, foram construídos mapas com informações vetoriais e raster, utilizando para tal, ferramentas de geoprocessamento disponíveis no ArcGIS 10. 
Assim a análise seguiu duas vertentes distintas, porém semelhantes nos processamentos e modelos aplicados, possibilitando a comparação entre os resultados alcançados.

A primeira etapa realizada foi um pré-processamento com intuito de adequação dos dados espaciais, uma vez que é necessário uniformizá-los para se reduzir o risco de inconsistências e possibilitar seu armazenamento em banco de dados geográfico.

O primeiro pré-processamento realizado foi a alteração do DATUM e do sistema de coordenadas trabalhado, já que a maioria dos dados provenientes das bases públicas estão comumente em DATUM SAD 69 e o IBGE alerta que: "os dados fornecidos pelo SAD69 e pelo SIRGAS2000 não são compatíveis entre si, ou seja, não podem ser inseridos num mesmo mapa. Há um deslocamento espacial entre as coordenadas determinadas pelos dois sistemas (variável, dependendo do local onde se está). A distância média para o mesmo ponto em SAD69 e SIRGAS2000 é algo em torno de 65 metros", além disso os demais sistemas de coordenadas não serão aceitos oficialmente após 2014. Utilizou-se portanto, a ferramenta Project do ArcGIS 10, e as transformações realizadas foram do DATUM SAD 69 para SIRGAS 2000 e WGS 84 para SIRGAS 2000. Ainda, a escolha em se manipular os dados em sistema de coordenadas geográficas se deve ao fato de que o recorte espacial em estudo atravessa dois fusos, o que dificultaria o trabalho com sistema de projeção cartográfica.

A segunda etapa ficou a cargo da realização da seleção dos dados espaciais para análise, exceto os de uso do solo do PROBIO, contidos nos limites estaduais do Rio de Janeiro e do Espírito Santo, através da ferramenta Clip que funciona extraindo feições do plano de informação ou camada existente a partir de um polígono pré-estabelecido. Tal ferramenta é particularmente útil para elaboração de novas feições que estejam inseridas na área de interesse estudada. Assim se utilizou apenas informações relevantes ao estudo apresentado, o que se converte em ganho de desempenho em processamento, uma vez que menos dados são utilizados. A figura 6 adiante ilustra a ferramenta Clip. 


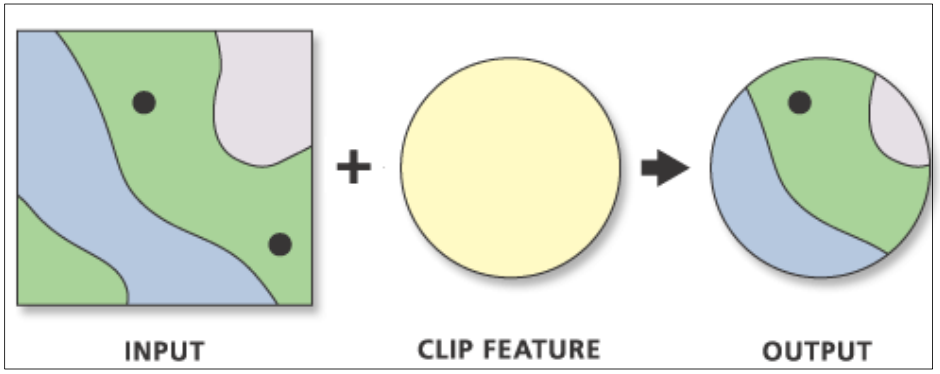

Figura 6: Processo de Clip. Fonte: ESRI

Ainda, foram estabelecidas as zonas de amortecimento de Unidades de Conservação (3 km), Terras Indígenas (5 km) e Comunidades Quilombolas (5 km) utilizando a ferramenta buffer que permite a elaboração de um raio a partir de determinada geometria do dado espacial. Esse processamento gera um novo dado espacial, que pode ser incorporado ao mapa. Um exemplo de seu uso é o estabelecimento de faixa de servidão para linhas de transmissão de energia.

A figura 7 a seguir demonstra seu funcionamento e as geometrias para as quais é possível gerar um buffer.

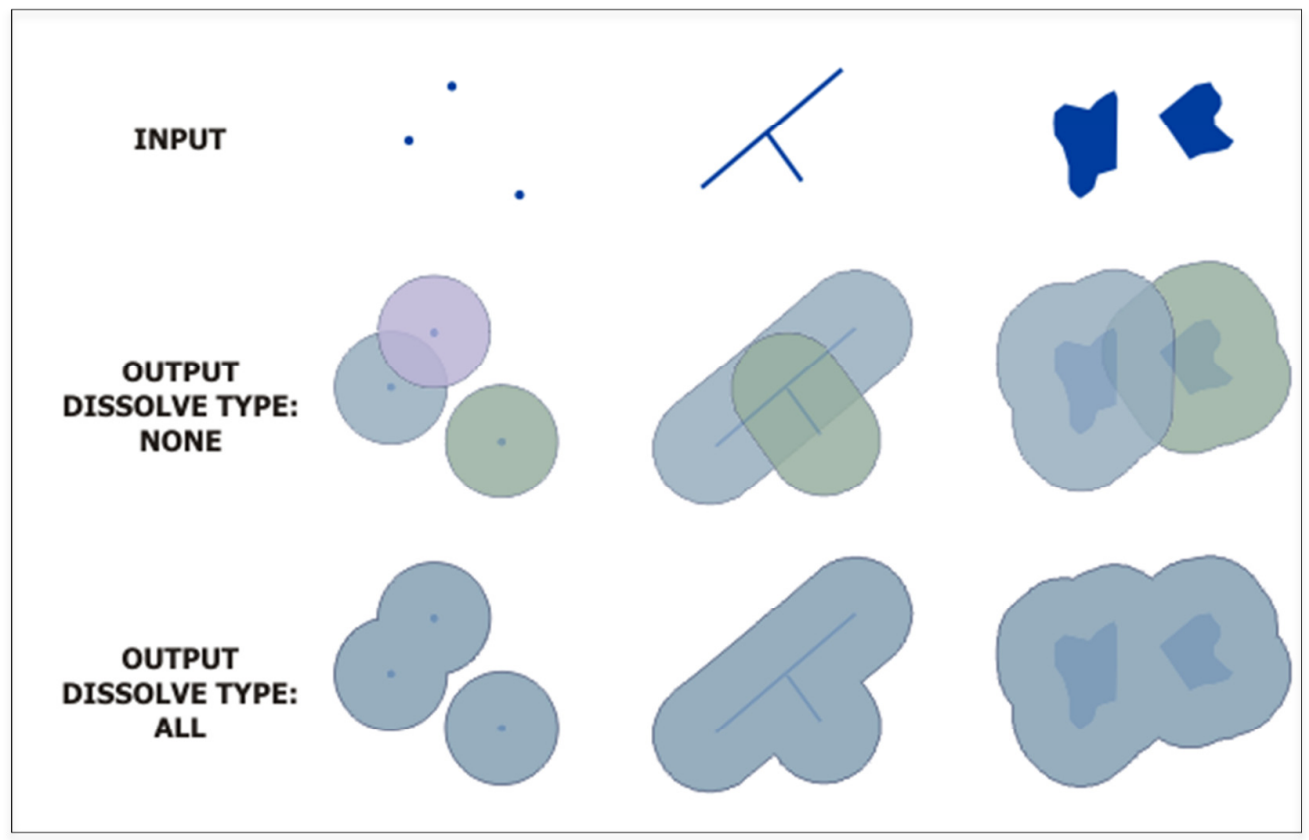

Figura 7: Processo Buffer. Fonte: ESRI

Finalmente, na etapa de pré-processamento, foram atribuidos valores para os aspectos socioambientais identificados nas bases públicas oficiais. Essa ação é fundamental para a realização das análises espaciais por map overlay que constitui 
uma das ferramentas mais vantajosas dos Sistemas de Informações Geográficas por fornecer a justaposição da informação em um arquivo agrupado. Este modelo foi utilizado para avaliar e agregar os critérios oriundos das informações existentes ou geradas. Assim os valores atribuídos aos aspectos socioambientais legais são o reflexo das restrições legais que serão somadas e ponderadas mais adiante.

Buscou-se estabelecer graus de restrições ambientais identificados na legislação, que tornaram possível a qualificação de cada uma das categorias selecionadas para compor a base de dados para análise espacial.

Para a avaliação dos aspectos ambientais levantados, foi gerada uma categorização levando em consideração não só o contexto técnico ambiental, mas também a questão legal. Para a análise legal, foram consideradas as restricõos legais objetivas (aquelas em que a norma define claramente metragem de recuo, distâncias a serem observadas em relação às restrições, por exemplo, ao tutelar as APPs a própria norma indica quais serão os recuos a observar), e as restricões legais não objetivas (indicam a existência de uma restrição legal, mas não há parâmetros numéricos/quantitativos que devam ser observados - como exemplo, unidades de conservação de uso sustentável).

Considerando o exposto, a categorização apresenta-se da seguinte forma (com relação à necessidade de desvio ferroviário):

1. Desnecessário;

2. Negociável;

3. Desnecessário - com aspectos mapeados;

4. Preferencial;

5. Necessário. 
Áreas de Desvio Necessário - trata-se daquelas áreas que sob a ótica técnica e legal dos aspectos observados, recomenda-se o não lançamento do traçado ferroviário. Tais localidades são protegidas por aspectos legais objetivos vedativos. Tem-se, ainda, como para o caso das Manchas Urbanas, a recomendação das entidades gestoras em âmbito governamental, orientações para a necessidade de se afastar o traçado destas localidades. ${ }^{1}$ São elas:

- Locais em que haja cavidades naturais subterrâneas cadastradas; ${ }^{2}$

- Unidades de conservação de proteção integral ${ }^{3,4}$, nos termos da Lei $n^{\circ}$ 9.985/2000 (Sistema Nacional de Unidades de Conservação da Natureza SNUC), em virtude da proteção integral somente contemplar uso indireto dos atributos naturais e da previsão de se manter essas áreas livres de alterações causadas por interferência humana (art. $2^{\circ}$, VI, c/c art. $7^{\circ}$, do SNUC);

- Sítios detentores de reminiscências históricas dos antigos quilombos ${ }^{5}$, por terem sido tombados pela Constituição Federal (art. 216, § 5º);

\footnotetext{
${ }^{1}$ A opção pela efetivação do desvio destas áreas fica, no entanto, a cargo das empresas desenvolvedoras dos projetos, uma vez que tal alteração pode implicar na perda de eficiência ferroviária, não atendimento a parâmetros técnicos e geométricos, bem como implicar na inviabilidade financeira.

${ }^{2}$ Foi considerado o grau de restrição mais alto da metodologia uma vez que não é possível neste momento dos estudos, a determinação do grau de relevância das cavidades já mapeadas (esta etapa está ligada ao licenciamento ambiental, fase seguinte ao projeto). Sendo assim, é importante ressaltar que a categoria para esse aspecto pode ser rebaixada para um nível menos restritivo caso seja comprovado um grau de relevância inferior ao de relevância máxima. Para fins da presente categorização, sugere-se a aplicação da área de influência prevista no art. $4^{\circ}, \S 3^{\circ}$ da Resolução CONAMA n ${ }^{\circ} 347 / 2004$ - 250 m.

${ }^{3}$ Deverá ser verificada a existência de plano de manejo que indique as restrições ali previstas para a zona de amortecimento. Inexistindo, sugere-se a aplicação do art. $1^{\circ}, \S 2^{\circ}$ da Resolução CONAMA n ${ }^{\circ} 428 / 2010-3 \mathrm{~km}$.

${ }^{4}$ Para trechos que possuam licença de operação válida e que atravessem UCs, a categoria de restrição utilizada será "Áreas de desvio negociável", pois se entende que a Licença de Operação já avaliou a viabilidade do empreendimento existente frente à Unidade de Conservação.

${ }_{5}^{5}$ A Fundação Palmares não disponibiliza a localização exata e delimitação das terras pertencentes às comunidades quilombolas existentes. Diante disto fez-se o trabalho de busca da localização pontual destas comunidades. De posse desta informação pontual e diante da inexistência de informações acerca dos limites precisos dos referidos territórios, adotou-se um buffer de $5 \mathrm{~km}$ (10 km para os casos dentro da Amazônia Legal) observando as premissas da Portaria Interministerial n 419 de 26/10/2011, como área de Desvio Necessário, visando ampliar as garantias de que o projeto não coincidirá com as terras em análise. Para os casos em que as comunidades não puderam ser localizadas pontualmente, manteve-se a informação de restrição em nível municipal, conforme disponibilizado pela Fundação Palmares.
} 
- Áreas ocupadas por comunidades indígenas (terras indígenas).

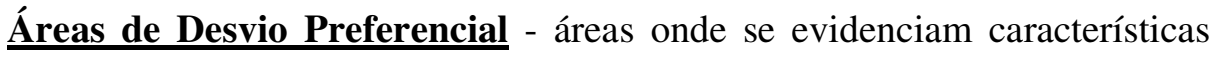
ambientais relevantes e, no entanto, para o momento e profundidade do estudo em desenvolvimento não se pode afirmar precisamente a efetividade de atributos ambientais com incidências legais objetivas e vedativas. Tecnicamente para o momento, acata-se a passagem dos trechos por estas áreas. Entretanto, salienta-se a possibilidade de que num momento futuro, quando de uma análise mais pormenorizada da intervenção ambiental do empreendimento, a saber, o momento de seu licenciamento ambiental, o projeto pode vir a encontrar zonas delicadas em termos ambientais com incidência inclusive de vedações legais objetivas. São elas:

- Áreas de alto potencial de ocorrência de cavidades naturais subterrâneas (sugere-se o desvio dessas áreas em função de estudos ambientais pontuais ainda não terem sido realizados, vislumbrando-se a possibilidade de que, no momento de sua execução, possa vir a ser encontrada cavidade de grau máximo de relevância, cuja supressão é vedada, nos termos do art. $3^{\circ}$, do Decreto 99.556/1990);

- Áreas de Mata Atlântica (Lei 11.428/2006)

Áreas de Desvio Negociável - aquelas em que não se recomenda lançar o traçado da ferrovia por haver algum tipo de restrição legal não objetiva e assim dependerem da avaliação de impactos por meio de órgãos gestores; ou áreas que possuam restrições legais objetivas e que haja a previsão de sua flexibilização por meio da adoção de medidas mitigadoras e/ou compensatórias; são elas:

- Unidades de conservação de uso sustentável (deve ser verificada a existência de plano de manejo a fim de que seja confirmada a inexistência 
de restrição objetiva. Caso esta exista, a categorização poderá vir a ser alterada) ${ }^{6}$;

- Áreas de Mata Atlântica que apresentem vegetação primária ou secundária nos estágios avançados e médio de regeneração, desde que seja adotada medida compensatória e que o empreendimento seja considerado de utilidade pública pelo poder público federal ou dos Estados (Lei $n^{\circ}$ 11.428/2006, art. $3^{\text {o }}$ VII, c/c art. 14, c/c art. 17). Em casos específicos tal categoria poderá ser revista para grau mais restritivo em termos da possibilidade de intervenção ${ }^{7}$.

- Entorno de terras quilombolas ${ }^{8}$, na distância de 10 km na Amazônia Legal e $5 \mathrm{~km}$ nas demais regiões, em que há presunção de ocorrência de impactos, até que o estudo ambiental do licenciamento prévio os especifique, nos termos do art. $3^{\circ}, \S 2^{\circ}$, inc. II da Portaria Interministerial $n^{\circ} 419 / 2011$;

- Entorno de comunidades indígenas (distância de 10 km na Amazônia legal e de $5 \mathrm{~km}$ nas demais regiões, em que há presunção de ocorrência de impactos, até que o estudo ambiental do licenciamento os especifique, nos termos do art. $3^{\circ}, \S 2^{\circ}$, inc. II da Portaria Interministerial $n^{\circ} 419 / 2011$ ).

Áreas de Desvio Desnecessário (com aspectos mapeados) - aquelas áreas onde não há necessidade legal objetiva e técnica recomendando a necessidade de

\footnotetext{
${ }^{6}$ Deverá ser verificada a existência de plano de manejo que indique as restrições ali previstas para a zona de amortecimento. Inexistindo, sugere-se a aplicação do art. $1^{\circ}, \S 2^{\circ}$ da Resolução CONAMA n ${ }^{\circ} 428 / 2010$ - $3 \mathrm{~km}$ - esse dispositivo não se aplica às reservas particulares do patrimônio natural e às áreas de proteção ambiental.

${ }^{7}$ Áreas de mata atlântica que apresentem vegetação primária ou nos estágios avançados e médio de regeneração quando a vegetação: abrigar espécies da flora e da fauna silvestres ameaçadas de extinção e a intervenção puser em risco a sobrevivência dessas espécies; exercer a função de proteção de mananciais ou de prevenção e controle de erosão; formar corredores entre remanescentes de vegetação primária ou secundária em estágio avançado de regeneração; proteger o entorno das unidades de conservação; possuir excepcional valor paisagístico, reconhecido pelos órgãos executivos competentes do SISNAMA; ou, quando o proprietário ou posseiro não cumprir os dispositivos da legislação ambiental, em especial as exigências do Código Florestal, em relação às Áreas de Preservação Permanente e à Reserva Legal (art. 11, Lei 11.428/2006).

${ }^{8}$ Aplica-se neste estudo somente para aquelas com os limites de terras disponibilizados pelos órgãos competentes.
} 
desvio do trecho ferroviário havendo, no entanto, atributos ambientais mapeados e que devem ser observados. São elas:

- Zona de amortecimento de Unidades de conservação ${ }^{9}$.

- Áreas inseridas no Mapa de Áreas Prioritárias para Conservação Ambiental do MMA.

Áreas de Desvio Desnecessário - áreas onde não foram mapeados/não existem aspectos ambientais relevantes.

Definidas as escalas de restrições e seus respectivos valores, foram adicionados campos nas tabelas de atributos dos dados espaciais socioambientais legais. Por estarem tais dados em formato vetorial, pode-se realizar a operação de Calculate Field, ferramenta de cálculo de valores para campos da tabela de atributos de dados espaciais. Efetivamente, a ferramenta em questão atribui um valor ao campo, possibilitando assim operações aritmétricas como a soma de valores.

\subsubsection{Processamento de dados em formato vetorial}

Cumprida a etapa de pré-processamento, foram aplicadas aos dados espaciais socioambientais legais oriundos de bases públicas, operações com o uso de ferramentas de geoprocessamento. Tais operações estão ilustradas nas figuras 8,9 e 10 a seguir:

- Dissolve: Ferramenta que agrega feições de um dado espacial, com base em um atributo específico ou em vários atributos presentes no dado espacial trabalhado, como no exemplo abaixo:

\footnotetext{
${ }^{9}$ Destaca-se que na existência de Plano de Manejo, o mesmo deve ser considerado.
} 


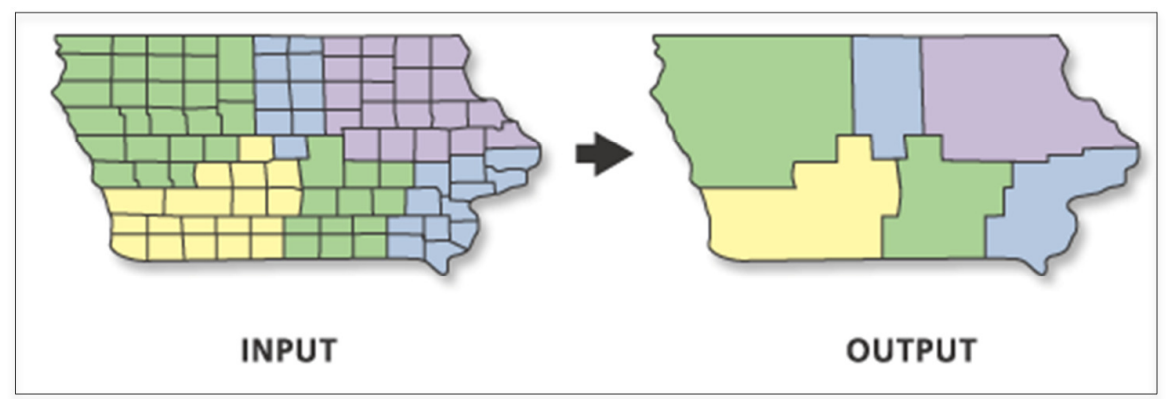

Figura 8: Processo Dissolve. Fonte: ESRI

- Select: Embora não seja uma ferramenta de geoprocessamento, é um método de seleção para escolher feições dentro da tabela de atributos de dados espaciais, através da realização de uma query (questionamento ou pergunta), com a sintaxe apropriada. Como exemplo, podemos citar seu uso na seleção de todos os municípios contidos em uma determinada Unidade da Federação.

- Merge: Combina dois ou mais feições de dados espaciais em uma nova feição unificada. Essa ferramenta pode ser aplicada em qualquer geometria de dado espacial e inclusive entre tabelas de atributos, contanto que respeite a regra de combinar múltiplas feições que apresentam a mesma geometria. Ou seja: uma linha só pode ser combinada com outra linha, nunca com um polígono ou ponto, como pode ser visto na figura adiante.

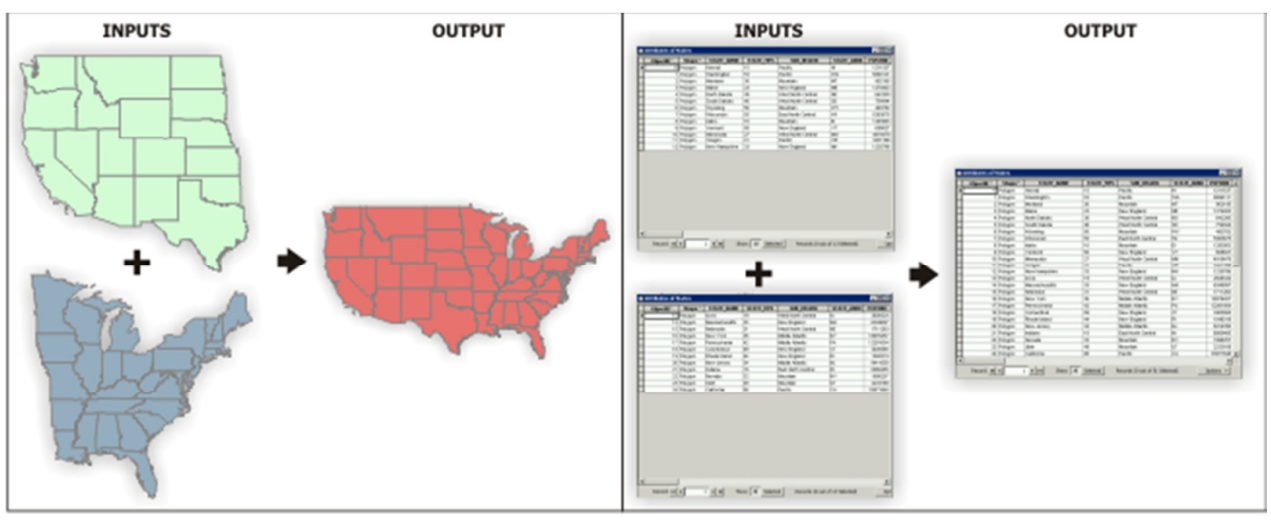

Figura 9: Processo Merge. Fonte: ESRI

- Union que gera, através do cálculo da união geométrica entre dados espaciais, um novo dado espacial, conservando a tabela de atributos 
de entrada. A seguir, pode-se apreciar um exemplo desse processamento:

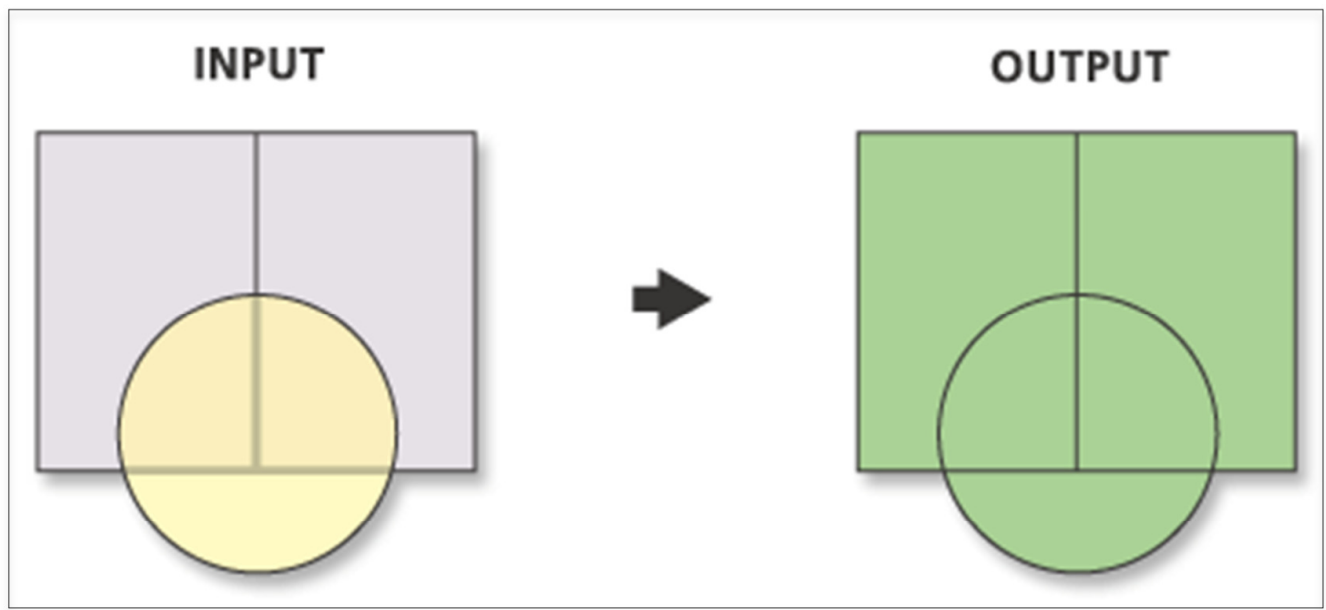

Figura 10: Processo Union. Fonte: ESRI.

Por fim, foi criado novo campo e aplicada a ferramenta Calculate Field para elaboração dos modelos de Map Overlay "Soma", mais simples e "Média Ponderada", mais complexo, com intuito de se visualizar através de mapa as áreas mais ou menos restritas sob a ótica socioambiental legal.

No modelo "Soma", os valores dos atributos previamente definidos, de cada aspecto socioambiental legal, foram adicionados, gerando novos temas para inserção no mapa.

Nos cálculos envolvendo média aritmética simples, todas as ocorrências têm exatamente a mesma importância ou o mesmo peso. Dizemos então que elas têm o mesmo peso relativo. No entanto, existem casos onde as ocorrências têm importância relativa diferente. Nestes casos, o cálculo da média deve levar em conta esta importância relativa ou peso relativo. Este tipo de média chama-se média aritmética ponderada.

Ponderar é sinônimo de pesar. No cálculo da média ponderada, multiplicamos cada valor do conjunto por seu "peso", isto é, sua importância relativa. 
A média aritmética ponderada $\bar{x}_{\mathrm{p}}$ de um conjunto de números $\mathrm{x} 1, \mathrm{x} 2, \mathrm{x} 3, \ldots$, xn cuja importância relativa ("peso") é respectivamente $\mathrm{p}_{1}, \mathrm{p}_{2}, \mathrm{p}_{3}, \ldots, \mathrm{p}_{\mathrm{n}}$ é calculada da conforme apresentado na equação 1:

$$
\bar{x}_{p}=\frac{p_{1} \cdot x_{1}+p_{2} \cdot x_{2}+p_{3} \cdot x_{3}+\ldots+p_{n} \cdot x_{n}}{p_{1}+p_{2}+p_{3}+\ldots+p_{n}}=\frac{\sum_{i=1}^{n}\left(p_{i}{ }^{*} x_{i}\right)}{\sum_{i=1}^{n} p_{i}}
$$

Equação 1: Média ponderada.

Esta etapa do trabalho, com os processamentos realizados, pode ser ilustrada através dos fluxogramas a seguir. Estão representados os dados divididos nos temas "Meio Físico", "Meio Biótico" e "Meio Socioeconômico", seguindo as práticas adotadas no planejamento ambiental, bem como na Lei 6.938/81. Vale ressaltar que, para os dados vetoriais, os processamentos foram realizados em suas tabelas de atributos, através de operações aritmétricas, diferentemente do que pode ser feito através de dados raster e que também será abordado no presente estudo.

Foram categorizados como Meio Biótico as Áreas Prioritárias para Conservação da Biodiversidade, Fragmentos Florestais protegidos pela Lei da Mata Atlântica e as Unidades de Conservação definidas no Sistema Nacional de Unidades de Conservação (SNUC). Segue abaixo os fluxogramas demonstrando os processamentos realizados para os dados categorizados como Meio Biótico:

Para os dados de Áreas Prioritárias para Conservação da Biodiversidade, denominado no banco de dados de AREA_PRIORITARIA.shp, foi adicionado à sua tabela de atributos um campo APPC_PESO. Posteriormente foi realizada a operação Calculate Field, que atribuiu a esse aspecto valor 2, correspondendo à Área de Desvio Desnecessário com Aspectos Mapeados. Por último, os polígonos diferentes que compõem o dado AREA_PRIORITARIA.shp foram agrupados para tornarem-se vários polígonos com os mesmos valores, através da ferramenta Dissolve. Esse processo pode ser observado na Figura 11 e Tabela 2 a seguir. 
Meio Biótico: Áreas Prioritárias para Conservação

$\begin{array}{lll}\text { Dados de Entrada } & \text { Alias do arquivo de entrada } & \text { Topologia } \\ \text { AREA_PRIORITARIA } & \text { Áreas Prioritárias para Conservação } & \text { Poligono }\end{array}$

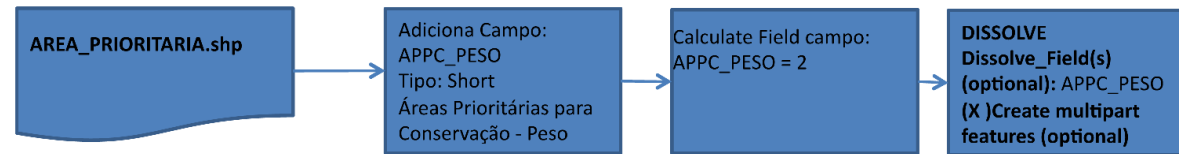

Figura 11: Fluxograma de processamento de dados para Áreas Prioritárias para Conservação da Biodiversidade. Fonte: própria.

Tabela 2: Valores atribuídos para Áreas Prioritárias para Conservação de Biodiversidade. Fonte: própria

\begin{tabular}{|c|c|c|}
\hline $\begin{array}{c}\text { Variável Meio } \\
\text { Biótico }\end{array}$ & Valoração & $\begin{array}{c}\text { Codificação na } \\
\text { Tabela de Atributos }\end{array}$ \\
\hline \multirow{2}{*}{$\begin{array}{c}\text { Áreas Prioritárias } \\
\text { para Conservação }\end{array}$} & $\begin{array}{c}\text { Área desvio } \\
\text { desnecessário com } \\
\text { aspectos mapeados }\end{array}$ & 2 \\
\cline { 2 - 3 } & $\begin{array}{c}\text { Área de desvio } \\
\text { desnecessário }\end{array}$ & 1 \\
\hline
\end{tabular}

Para os dados de Lei da Mata Atlântica - Fragmentos Florestais, denominado no banco de dados de USO_DO_SOLO_PROBIO_MMA.shp, foi adicionado à sua tabela de atributos um campo FR_FL_PESO. Posteriormente foi realizada uma seleção de classes de uso do solo relacionadas a tipologias florestais, como se nota na lista apresentada no fluxograma abaixo. Uma vez selecionadas as classes de uso do solo relevantes para a análise, foi executada a operação Calculate Field, que atribuiu valor 4 a esse aspecto, correspondendo à 
Área de Desvio Preferencial. Ressalta-se que, devido à proposta do presente estudo estar restrita a utilização de dados secundários de fontes públicas oficiais, não foram realizados trabalhos de campo, aquisição de imagens e interpretação das mesmas para se estabelecer o estágio sucessional da vegetação e por isso, todas as classes selecionadas obtiveram o mesmo peso. Por último, os polígonos diferentes que compõe o dado USO_DO_SOLO_PROBIO_MMA.shp foram agrupados para tornarem-se vários polígonos com os mesmos valores, através da ferramenta Dissolve. Esse processo pode ser observado na Figura 12 e Tabela 3 a seguir.

Meio Biótico: Lei da Mata Atlântica - Fragmentos Florestais

$\begin{array}{lll}\text { Dados de Entrada } & \text { Alias do arquivo de entrada Topologia }\end{array}$

USO_SOLO_PROBIO_MMA Mapeamento de Uso do Solo - PROBIO I Polígono

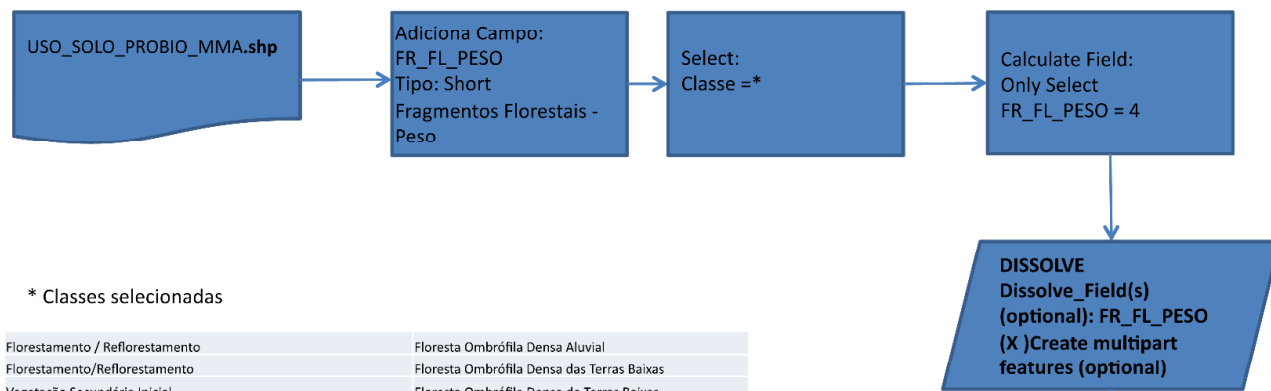

Thresta

Floresta Estacional / Floresta Ombrófila Mista _ Floresta Ombrófila Densa Montana

Floresta Ombróflla Densa/ Floresta Ombrófila Mista Floresta Ombrófila Densa Submontana

Savana Gramineo-Lenhosa

Floresta Estacional Decidual Montana

Floresta Ombrófla Mista Alto-Montan

Floresta Ombrófila Mista Montan

Savana Estépica Florestada

Horesta Lstacional Semidecicual das Terras Baix

Floresta Estacional Semidecicual Montana

Floresta Estacional Semidecicual Submonta

Floresta Estacional Semidecidual Aluvial
Floresta Estacional Semidecidual das Terras Baixas

Savana Florestada

Savana Gramineo-Lenhosa

Refúgio Alto-montano

Refúgio Alto-Montano

Refúgio Montano

Refúgio Submontano

Floresta Estacional Semidecidual Montana

Floresta Estacional Semidecidual Submontana

Floresta Ombrófila Aberta Montana

Floresta Ombrófila Aberta Submontana

Floresta Ombrófila Densa Alto-montana

Refúgios Vegetacion is N Nto-Montan

Refúgios Vegetacionzis NAto-Mon

Refúgios Vegetacionals Submontan

Floresta Ombrófila Densa Alto-Montana

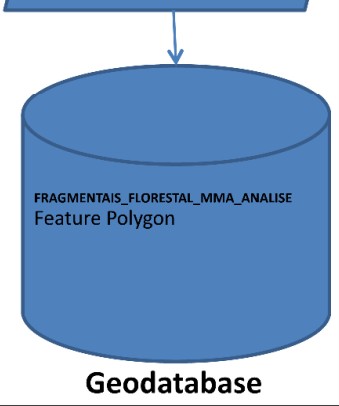

Figura 12: Fluxograma de processamento de dados para Mata Atlântica. Fonte: própria

Tabela 3: Valores atribuídos para Mata Atlântica. Fonte: própria.

\begin{tabular}{|c|c|c|}
\hline $\begin{array}{c}\text { Variável Meio } \\
\text { Biótico }\end{array}$ & Valoração & $\begin{array}{c}\text { Codificação na } \\
\text { Tabela de Atributos }\end{array}$ \\
\hline Lei da Mata \\
Atlântica (Fragmentos \\
\cline { 2 - 3 } Florestais) & $\begin{array}{c}\text { Área de desvio } \\
\text { preferencial }\end{array}$ & 4 \\
\cline { 2 - 3 } & $\begin{array}{c}\text { Área de desvio } \\
\text { desnecessário }\end{array}$ \\
\hline
\end{tabular}


Para os dados de Unidades de Conservação, denominado no banco de dados de UC.shp, foi adicionado à sua tabela de atributos um campo UC_PESO. Posteriormente foi realizada uma seleção dos grupos de Unidades de Conservação, como se nota na lista apresentada no fluxograma acima. Uma vez selecionados os grupos, foi executada a operação Calculate Field, para cada um desses grupos de Unidade de Conservação, atribuindo valor 5, correspondendo à Área de Desvio Necessário para o grupo Uso Integral e valor 3, correspondendo à Área de Desvio Desnecessário com Aspectos Mapeados para o grupo Uso Sustentável. Por último, os polígonos diferentes que compõe o dado UC.shp foram agrupados para tornarem-se vários polígonos com os mesmos valores, através da ferramenta Dissolve. Esse processo pode ser observado na Figura 13 e Tabela 4 a seguir.

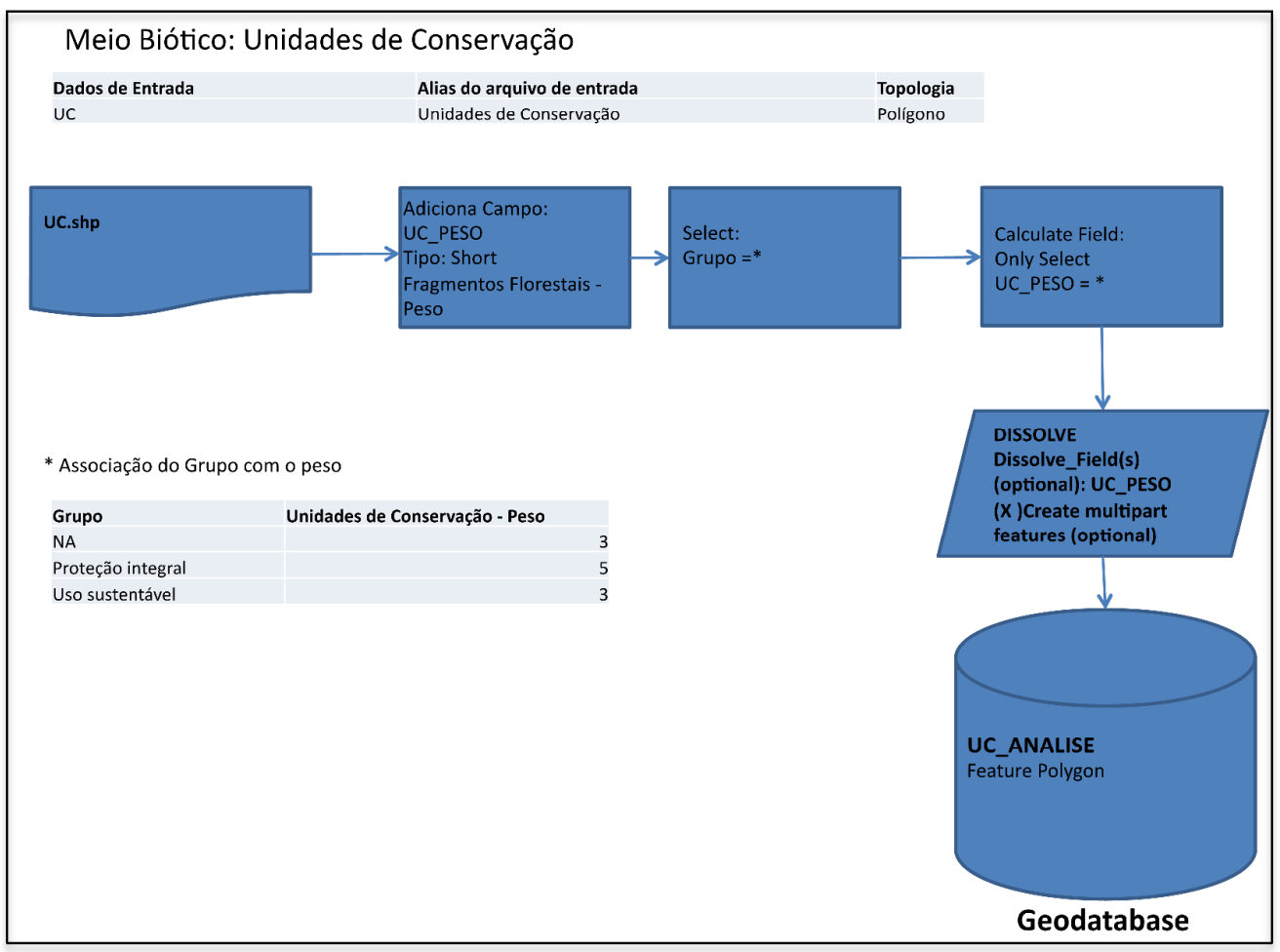

Figura 13: Fluxograma de processamento de dados para Unidades de Conservação. Fonte: própria. 
Tabela 4: Valores atribuídos para Unidades de Conservação. Fonte: própria.

\begin{tabular}{|c|c|c|}
\hline $\begin{array}{c}\text { Variável Meio } \\
\text { Biótico }\end{array}$ & Valoração & $\begin{array}{c}\text { Codificação na } \\
\text { Tabela de Atributos }\end{array}$ \\
\hline \multirow{3}{*}{$\begin{array}{c}\text { Unidades de } \\
\text { Conservação }\end{array}$} & $\begin{array}{c}\text { Área de desvio } \\
\text { necessário }\end{array}$ & 5 \\
\cline { 2 - 3 } & $\begin{array}{c}\text { Área de desvio } \\
\text { negociável }\end{array}$ & 3 \\
\cline { 2 - 3 } & $\begin{array}{c}\text { Área de desvio } \\
\text { desnecessário }\end{array}$ \\
\hline
\end{tabular}

Foram categorizados como Meio Físico as Cavidades Naturais e as áreas com Potencial Espeleológico. Segue adiante os fluxogramas demonstrando os processamentos realizados para os dados categorizados como Meio Físico.

Para os dados de Potencial Espeleológico, denominado no banco de dados de POT_ESPELEO.shp, foi adicionado à sua tabela de atributos um campo P_ESP_PESO. Posteriormente foi realizada uma seleção das classes por grau de potencialidade de ocorrência de cavernas, como se nota na lista apresentada no fluxograma acima. Uma vez selecionados os grupos, foi executada a operação Calculate Field, para cada uma dessas classes de potencial espeleológico, atribuindo valor 4, correspondendo à Área de Desvio Preferencial para as classes Alto e Muito Alto, valor 2, correspondendo à Área de Desvio Negociável para a classe Média e finalmente, atribuindo valor 1, correspondendo à Área de Desvio Desnecessário para as classes Baixa e Improvável. Por último, os polígonos diferentes que compõe o dado POT_ESPELEO.shp foram agrupados para tornarem-se vários polígonos com os mesmos valores, através da ferramenta Dissolve. Esse processo pode ser observado na Figura 14 e Tabela 5 a seguir. 


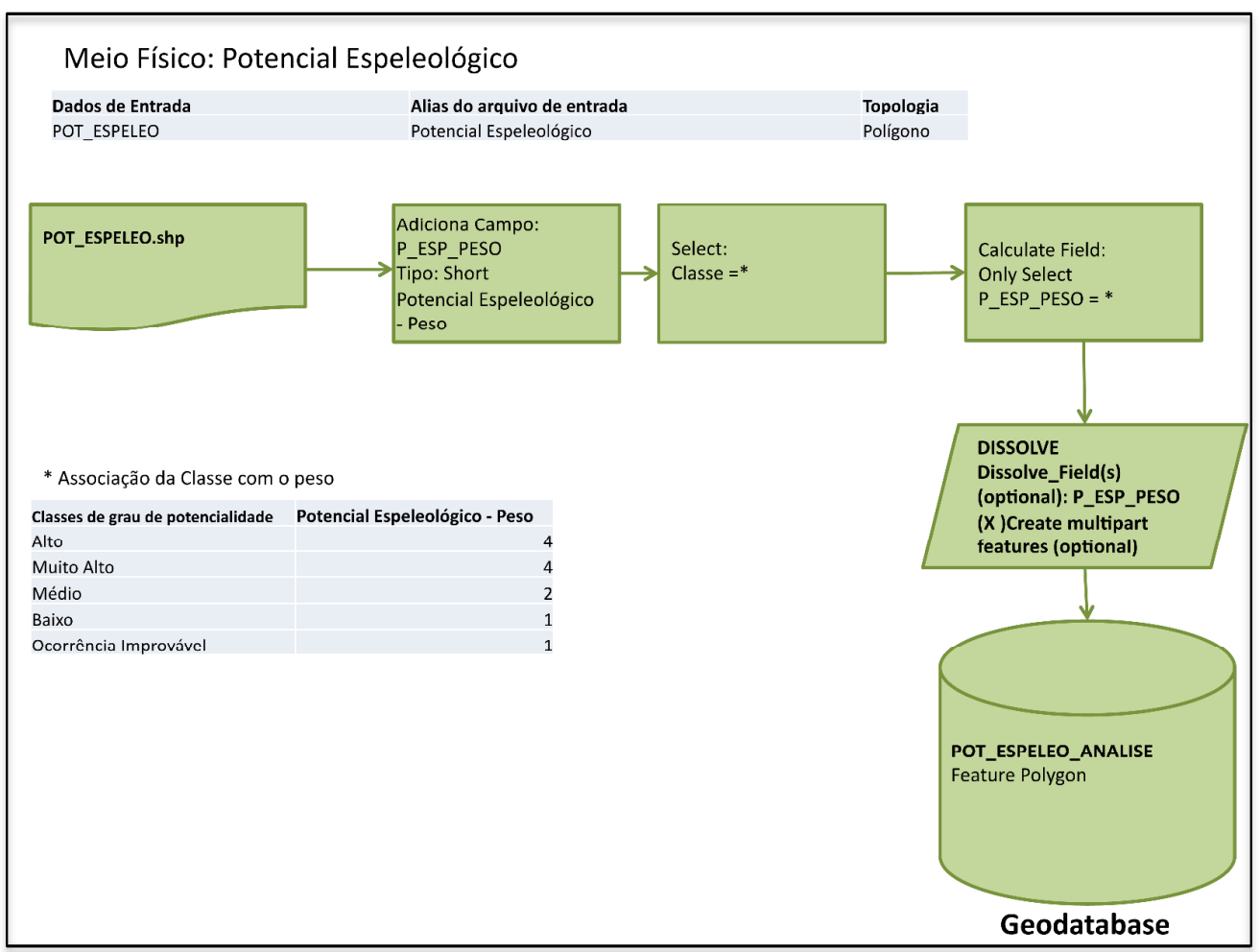

Figura 14: Fluxograma de processamento de dados para Potencial Espeleológico. Fonte: própria.

Tabela 5: Valores atribuídos para Potencial Espeleológico. Fonte: própria.

\begin{tabular}{|c|c|c|}
\hline $\begin{array}{c}\text { Variável Meio } \\
\text { Físico }\end{array}$ & Valoração & $\begin{array}{c}\text { Codificação na } \\
\text { Tabela de Atributos }\end{array}$ \\
\hline \multirow{2}{*}{$\begin{array}{c}\text { Potencial } \\
\text { Espeleológico }\end{array}$} & $\begin{array}{c}\text { Área de desvio } \\
\text { preferencial; }\end{array}$ & 4 \\
\cline { 2 - 3 } & $\begin{array}{c}\text { Área de desvio } \\
\text { negociável }\end{array}$ & 2 \\
\hline & Área de desvio & \\
\hline & desnecessário & \\
\hline
\end{tabular}

Para os dados de Cavidades Naturais, denominado no banco de dados de Cavidades.shp e de geometria pontual, primeiramente foi realizado um processo de Buffer de 250 metros a partir da localização das cavidades naturais, gerando um dado com geometria tipo polígono, conforme orienta a legislação. Logo após, foi adicionado à sua tabela de atributos um campo CAV_PESO. Em seguida, foi 
executada a operação Calculate Field, atribuindo valor 5, correspondendo à Área de Desvio Necessário. Por último, os polígonos diferentes que compõe o dado Cavidades.shp foram agrupados para tornarem-se vários polígonos com os mesmos valores, através da ferramenta Dissolve. Esse processo pode ser observado na Figura 15 e Tabela 6 a seguir.

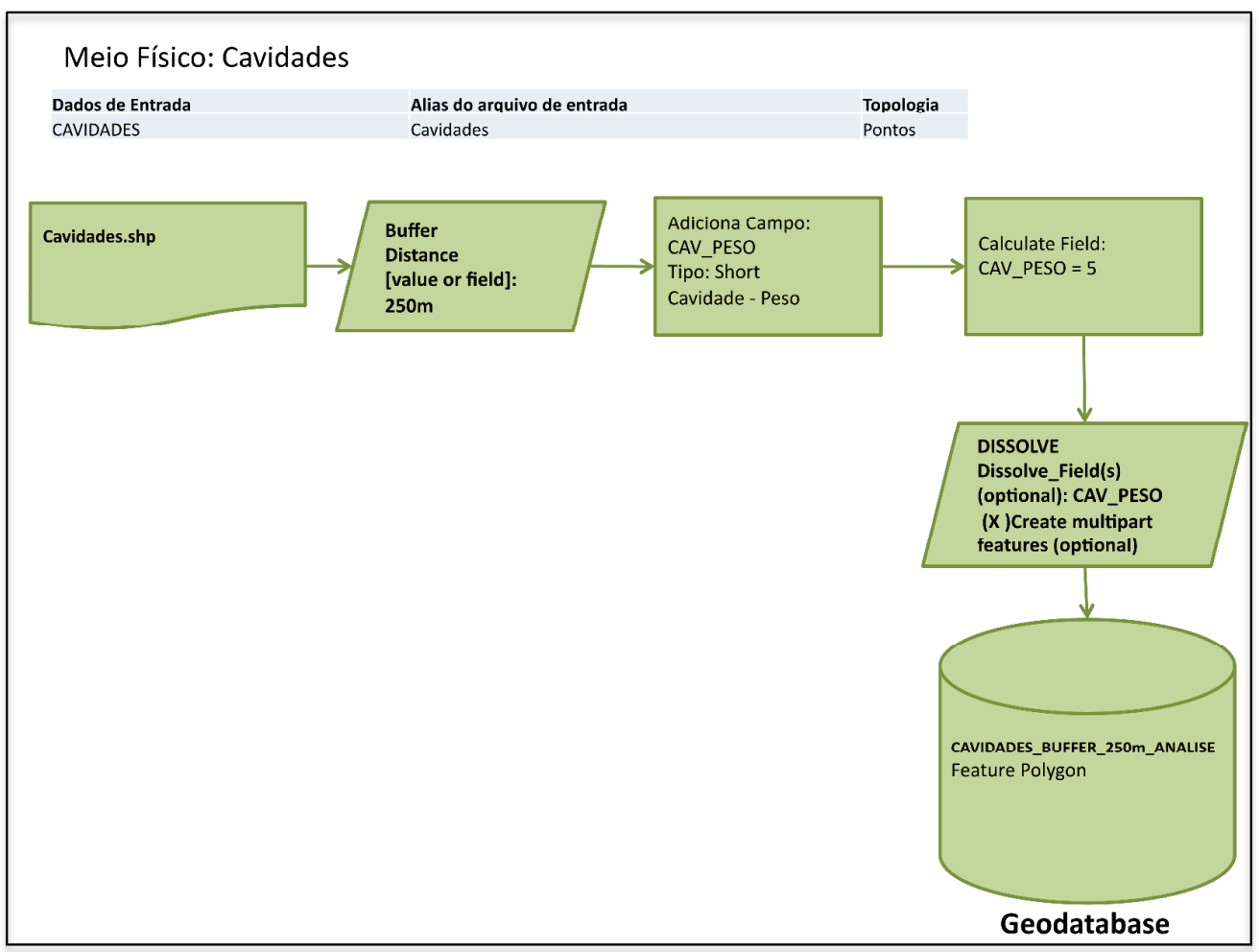

Figura 15: Fluxograma de processamento de dados para Cavidades Naturais. Fonte: própria.

Tabela 6: Valores atribuídos para Cavidades Naturais. Fonte: própria.

\begin{tabular}{|l|c|c|}
\hline $\begin{array}{c}\text { Variável Meio } \\
\text { Físico }\end{array}$ & Valoração & $\begin{array}{c}\text { Codificação na } \\
\text { Tabela de Atributos }\end{array}$ \\
\hline \multirow{2}{*}{ Cavidades } & $\begin{array}{c}\text { Área de desvio } \\
\text { necessário }\end{array}$ & 5 \\
\cline { 2 - 3 } & $\begin{array}{c}\text { Área de desvio } \\
\text { desnecessário }\end{array}$ \\
\hline
\end{tabular}


Foram categorizados como Meio Socioeconômico as Áreas Urbanizadas, classificadas pelo PROBIO, Comunidades Quilombolas e Terras Indígenas, sendo que para os dois últimos aspectos citados foi aplicado um raio de $5 \mathrm{~km}$ para sua área de influência, como estabelece a Lei. Segue adiante fluxograma demonstrando os processamentos realizados para as áreas os dados categorizados como Meio Socioeconômico.

Para os dados de Áreas Urbanas, denominado no banco de dados de AREAS_URBANIZADAS_ANALISE.shp, foi adicionado à sua tabela de atributos um campo AR_UR_PESO. Posteriormente foi realizada uma seleção de classes de uso do solo relacionadas a tipologias antropizadas, como se nota na lista apresentada no fluxograma acima. Uma vez selecionadas as classes de uso do solo relevantes para a análise, foi executada a operação Calculate Field, que atribuiu valor 5 correspondendo à Área de Desvio Necessário. Ressalta-se que, devido a proposta do presente estudo estar restrita a utilização de dados secundários de fontes públicas oficiais, não foram realizados trabalhos de campo, aquisição de imagens e interpretação das mesmas para se estabelecer áreas urbanas e por isso, todas as classes selecionadas obtiveram o mesmo valor. Por último, os polígonos diferentes que compõe o dado AREAS_URBANIZADAS_ANALISE.shp foram agrupados para tornarem-se vários polígonos com os mesmos valores, através da ferramenta Dissolve. Esse processo pode ser observado na Figura 16 e Tabela 7 a seguir. 


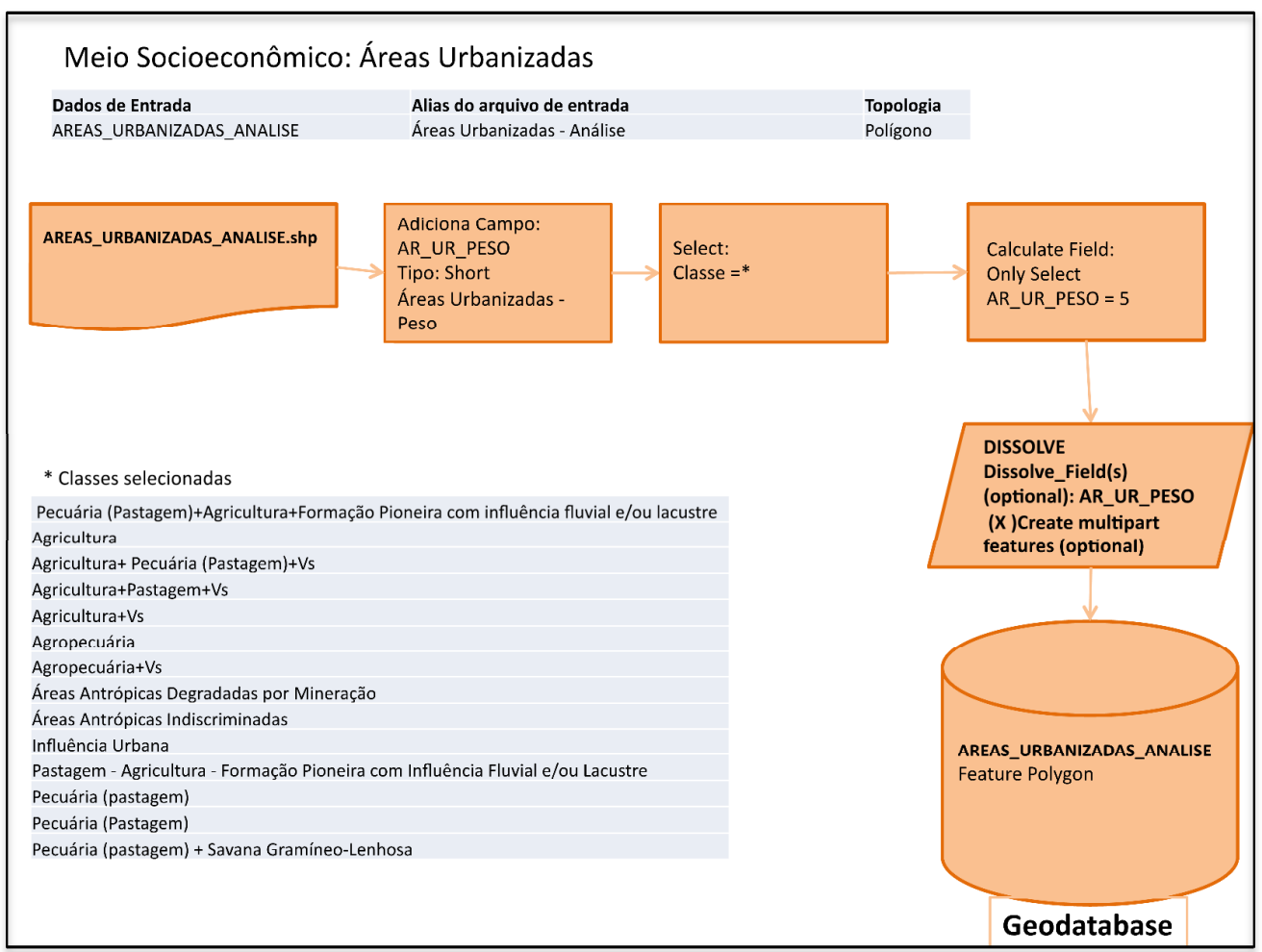

Figura 16: Fluxograma de processamento de dados para Áreas Urbanas/Antropizadas. Fonte: própria.

Tabela 7: Valores atribuídos para Áreas Urbanas/Antropizadas. Fonte: própria.

\begin{tabular}{|c|c|c|}
\hline $\begin{array}{c}\text { Variável Meio } \\
\text { socioeconômico }\end{array}$ & Valoração & $\begin{array}{c}\text { Codificação na } \\
\text { Tabela de Atributos }\end{array}$ \\
\hline \multirow{2}{*}{ Áreas Urbanizadas } & $\begin{array}{c}\text { Área de desvio } \\
\text { necessário }\end{array}$ & 5 \\
\cline { 2 - 3 } & $\begin{array}{c}\text { Área de desvio } \\
\text { desnecessário }\end{array}$ & 1 \\
\hline
\end{tabular}

Para os dados de Comunidades Quilombolas, denominado no banco de dados de COMUND_QUILOMB.shp, foi adicionado à sua tabela de atributos um campo COM_Q_PESO. Posteriormente foi executada a operação Calculate Field, que atribuiu valor 5, correspondendo à Área de Desvio Necessário. Também foram elaborados polígonos como resultado de aplicação de Buffer de $5 \mathrm{~km}$ a partir da delimitação da área de cada comunidade quilombola, pois é uma orientação legal. Em seguida, foi executado o processo de Merge, conforme demonstrado na figura logo após o fluxograma, para unir os polígonos de 
comunidades quilombolas aos polígonos gerados pelo Buffer. Como essa união de polígonos não aplica os mesmos valores da tabela de atributos original para os campos do novo polígono gerado, foi necessário refazer a operação Calculate Field para os valores que constavam na tabela como nulos, atribuindo a eles valor 5. Por último, os polígonos diferentes que compõe o dado COMUND_QUILOMB.shp foram agrupados para tornarem-se vários polígonos com os mesmos valores, através da ferramenta Dissolve. Esse processo pode ser observado na Figura 17 e Tabela 8 a seguir.

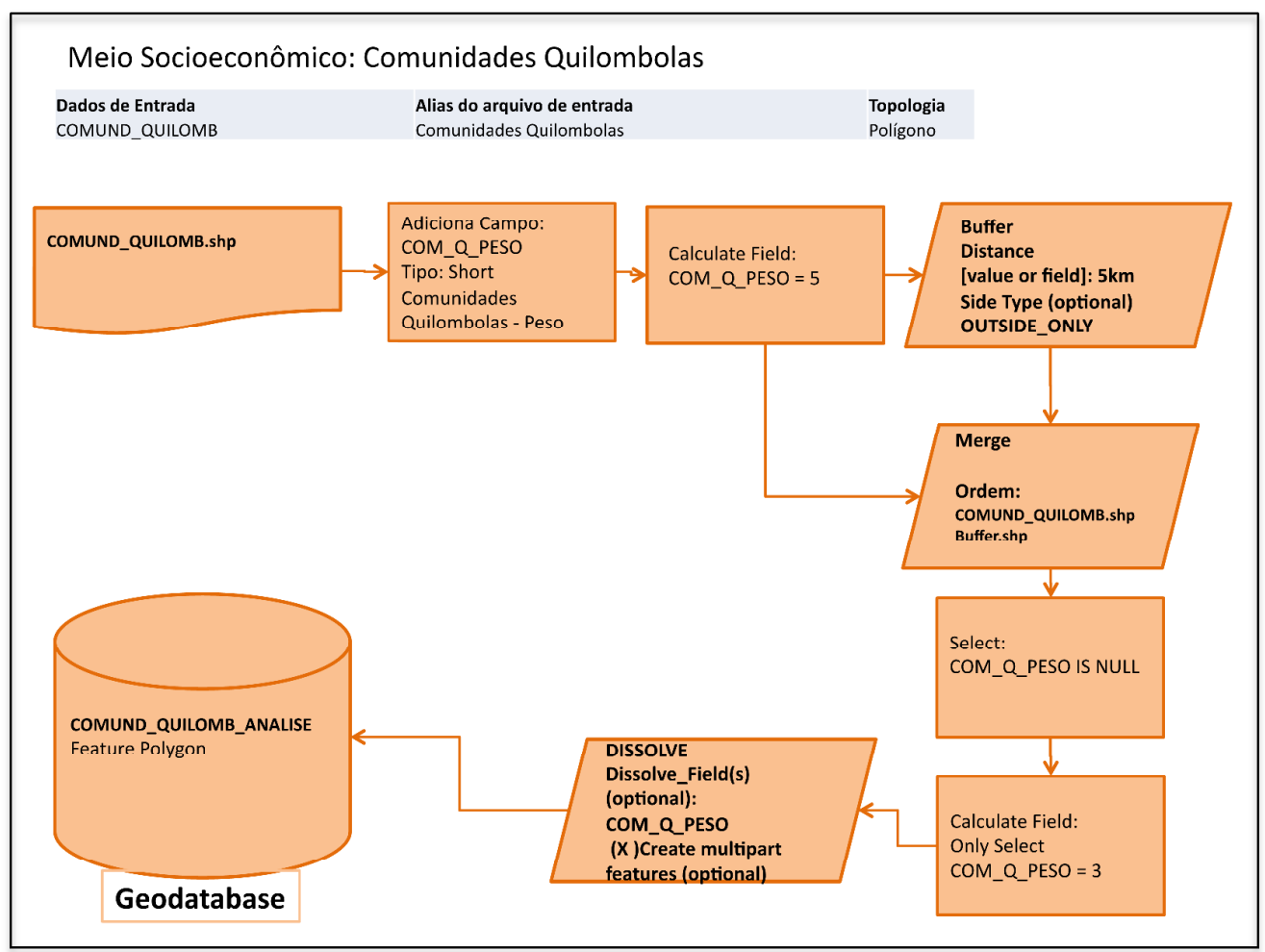

Figura 17: Fluxograma de processamento de dados para Comunidades Quilombolas. Fonte: própria. 
Tabela 8: Valores atribuídos para Comunidades Quilombolas. Fonte: própria.

\begin{tabular}{|c|c|c|}
\hline $\begin{array}{c}\text { Variável Meio } \\
\text { socioeconômico }\end{array}$ & Valoração & $\begin{array}{c}\text { Codificação na } \\
\text { Tabela de Atributos }\end{array}$ \\
\hline \multirow{3}{*}{$\begin{array}{c}\text { Comunidades } \\
\text { Quilombolas }\end{array}$} & $\begin{array}{c}\text { Área de desvio } \\
\text { necessário }\end{array}$ & 5 \\
\cline { 2 - 3 } & $\begin{array}{c}\text { Área de desvio } \\
\text { negociável }\end{array}$ & 3 \\
\cline { 2 - 3 } & $\begin{array}{c}\text { Área de desvio } \\
\text { desnecessário }\end{array}$ \\
\hline
\end{tabular}

Para os dados de Terras Indígenas, denominado no banco de dados de TERRA_INDIG.shp, foi adicionado à sua tabela de atributos um campo T_IND_PESO. Posteriormente foi executada a operação Calculate Field, que atribuiu valor 5, correspondendo à Área de Desvio Necessário. Também foram elaborados polígonos como resultado de aplicação de Buffer de $5 \mathrm{~km}$ a partir da delimitação da área de cada terra indígena, pois é uma orientação legal. Em seguida, foi executado o processo de Merge, para unir os polígonos de comunidades quilombolas aos polígonos gerados pelo Buffer. Como essa união de polígonos não aplica os mesmos valores da tabela de atributos original para os campos do novo polígono gerado, foi necessário refazer a operação Calculate Field para os valores que constavam na tabela como nulos, atribuindo a eles valor 5. Por último, os polígonos diferentes que compõe o dado TERRA_INDIG.shp foram agrupados para tornarem-se vários polígonos com os mesmos valores, através da ferramenta Dissolve. Esse processo pode ser observado na Figura 18 e Tabela 9 a seguir. 


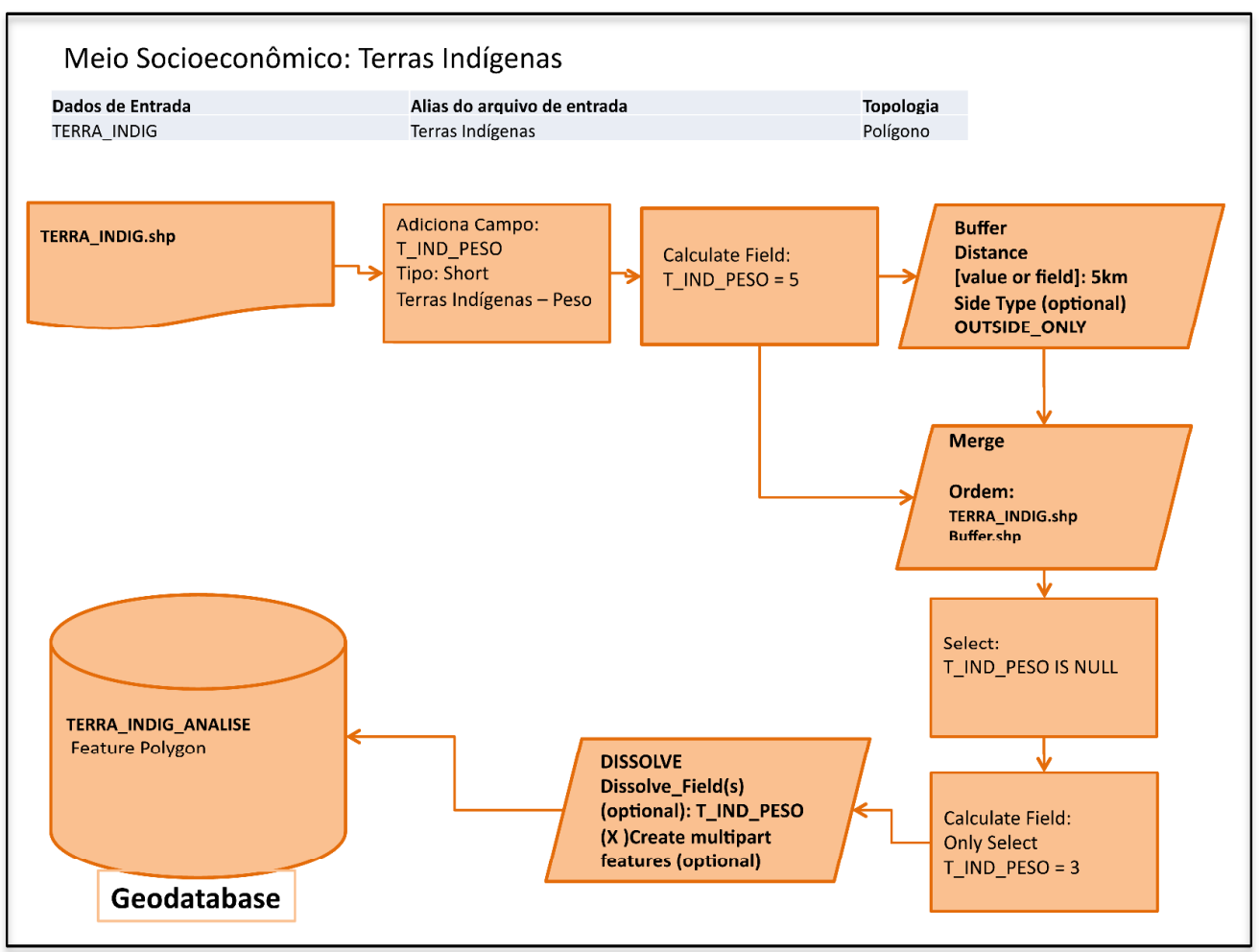

Figura 18: Fluxograma de processamento de dados para Terras Indígenas. Fonte: própria.

Tabela 9: Valores atribuídos para Comunidades Terras Indígenas. Fonte: própria.

\begin{tabular}{|c|c|c|}
\hline $\begin{array}{c}\text { Variável Meio } \\
\text { socioeconômico }\end{array}$ & Valoração & $\begin{array}{c}\text { Codificação na } \\
\text { Tabela de Atributos }\end{array}$ \\
\hline \multirow{3}{*}{ Terras Indígenas } & \begin{tabular}{c} 
Área de desvio \\
necessário \\
\cline { 2 - 3 }
\end{tabular} & $\begin{array}{c}\text { Área de desvio } \\
\text { negociável, } \\
\text { Área de desvio } \\
\text { desnecessário }\end{array}$ \\
\cline { 2 - 3 } & & 3 \\
\hline
\end{tabular}

Abaixo, a Figura 19 ilustra o fluxograma representando a etapa de sobreposição de dados socioambientais legais com seus respectivos pesos, utilizando as duas modelagens citadas. 


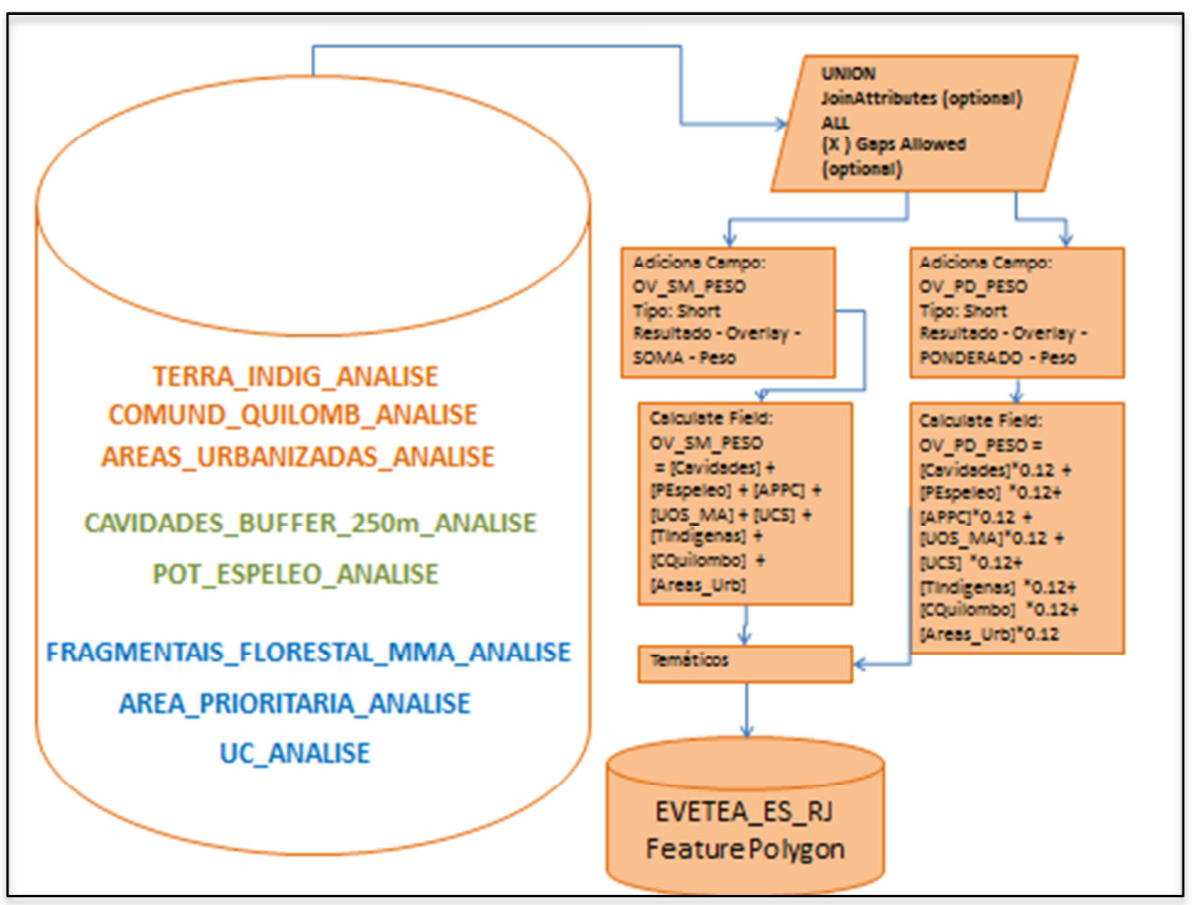

Figura 19: Fluxograma de processamento de dados de restrições socioambientais legais, para aplicação da equações "média ponderada" e de "soma" dos valores definidos. Fonte: própria.

\subsubsection{Processamento de dados em formato raster}

Como forma de comparação dos modelos adotados, a manipulação de dados raster também foi realizada e assim, com os resultados obtidos, pode-se ter mais um elemento para auxiliar a escolha mais adequada ao planejamento. Desta forma a tomada de decisão torna-se menos arriscada, sob a ótica de restrições socioambientais legais para empreendimentos de infraestrutura, como é o caso do presente estudo.

A etapa de processamento dos dados espaciais em formato raster, para compor o mapa de zoneamento de restrições socioambientais legais, foi realizada posteriormente aos pré-processamentos aplicados aos vetores. Tal escolha se deu por conta da necessidade de se atribuir valores para as restrições socioambientais legais, o que seria uma tarefa mais simples no formato vetor, uma vez que o mesmo possui tabela de atributos onde os dados alfanuméricos são manipulados facilmente e são os tipos de dados disponibilizados em bases públicas oficiais. 
Os processamentos dos dados raster se dão a partir dos dados vetor. Ou seja, após o pré-processamento dos dados vetor, os mesmos são convertidos para o formato raster. Os processamentos que diferem dos aplicados nos dados vetor estão exemplificados a seguir:

- Feature to Raster: Converte dados em formato vetorial, qualquer que seja sua geometria, em raster. A conversão transforma linhas, pontos e polígonos em células ou pixel que podem ter seus valores representados conforme os atributos dos dados vetoriais de origem. Assim, os valores de restrições definidos anteriormente são mantidos, o que significa dizer que cada célula possui um valor entre 1 e 5, para o estudo presente. Além disso, é necessário estabelecer um tamanho para as células que respeitem a escala de trabalho escolhida.

- Reclassify: Ferramenta para adequação de valores para as células de dados raster. De maneira geral, é uma ferramenta que permite atribuir um único valor a um intervalo de valores. Por exemplo, células com valores entre 1 e 5 podem ser reclassificadas para apresentarem valor 5. Além disso, permite a atribuir valores a células sem valor especificado, tornando uma posterior classificação fiel à realidade do fenômeno estudado.

- Weighted Sum: Sobrepõe diversas camadas raster, multiplicando cada uma delas por um peso pré-estabelecido, somando-os ao final, conforme observado na figura 20 a seguir.

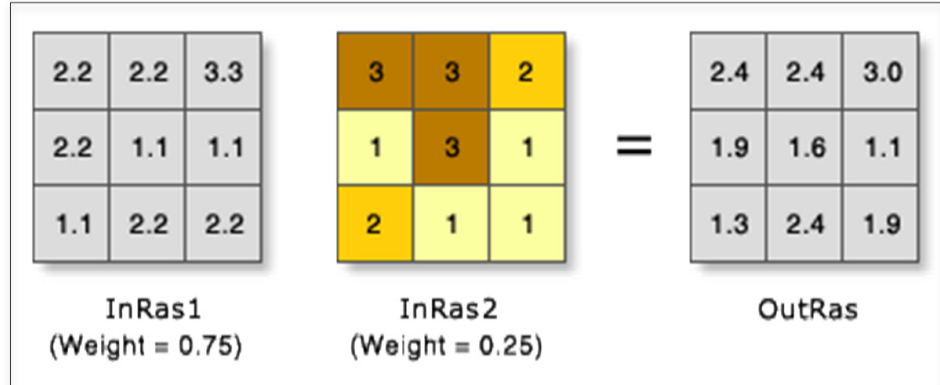

Figura 20: Esquema representativo da ferramenta Weightea' Sum. Fonte: ESRI. 
- Weighted Overlay: Sobrepõe diversas camadas raster utilizando uma escala comum de medidas, ponderando cada camada de acordo com sua importância, conforme observado na figura 21 a seguir.

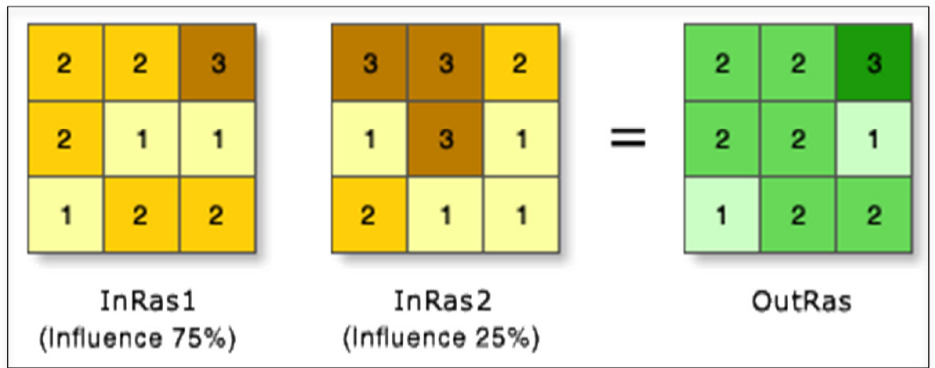

Figura 21: Esquema representativo da ferramenta Weightea' Overiay. Fonte: ESRI.

A diferença de modelagem entre os dados espaciais vetoriais para os dados em formato raster se diferenciam e tomam direções diferentes e podem ser apreciados no fluxograma a seguir na Figura 22.

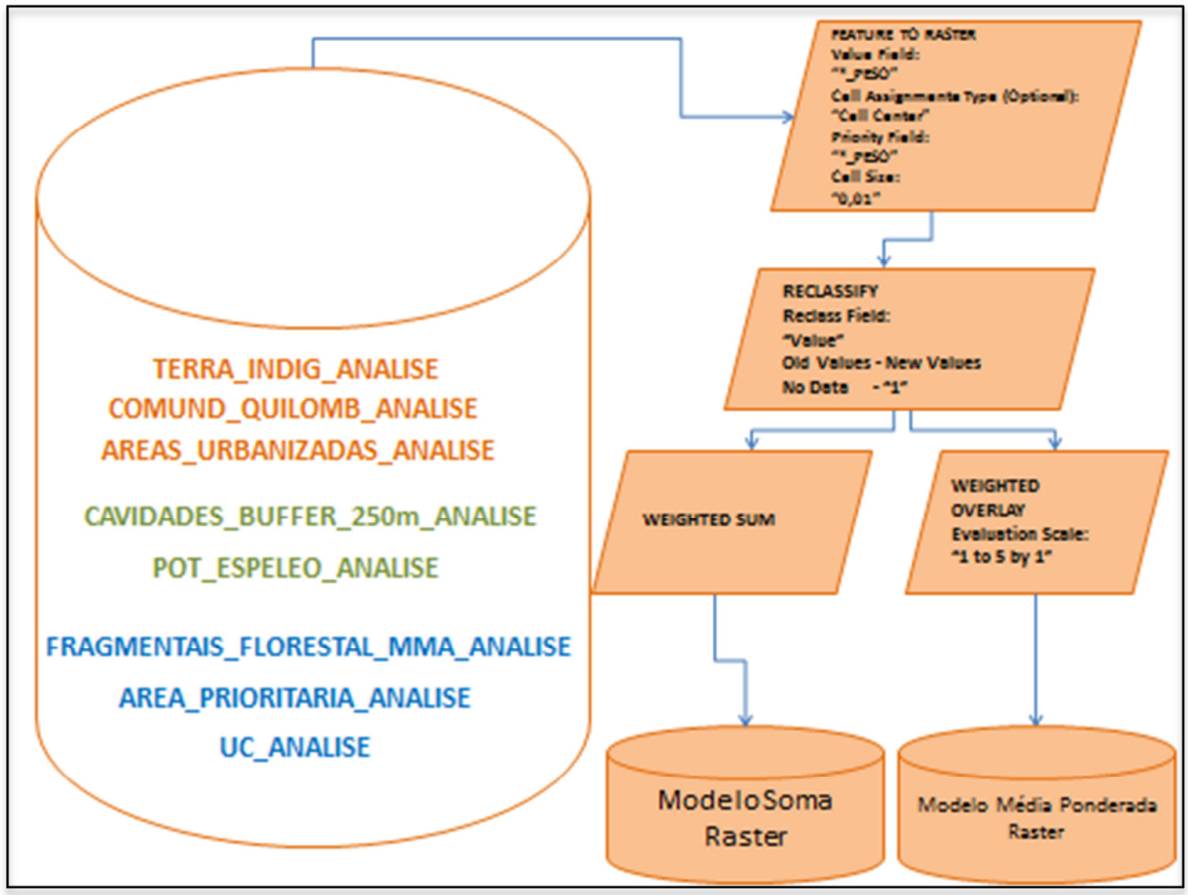

Figura 22: Fluxograma de processamento de dados de restrições socioambientais legais, para aplicação das ferramentas Weighted Sum (Soma Ponderada) e Weighted Overlay (Média Ponderada) em dados raster. Fonte: própria. 


\section{Resultados}

\subsection{Análise de dados socioambientais legais}

$\mathrm{O}$ presente trabalho se apropriou de técnicas de integração, manipulação e análise espacial de dados, visando o mapeamento de restrições legais de aspectos socioambientais à empreendimentos de infraestrutura, tendo como base planos de informações descritivos, criados a partir da análise qualitativa de informações socioambientais. O plano de trabalho adotado foi embasado em geoprocessamento como ferramenta para integrar e analisar as informações produzidas.

Foi realizado o levantamento de dados de aspectos socioambientais, definidos como tal pela legislação, com intuito de reconhecer a área de estudo. Os layers de cruzamento de dados foram produzidos com o apoio do Geoprocessamento, através de ferramentas específicas, utilizando para tanto o software comercial ArcGIS 10.

Para o mapeamento de restrições socioambientais legais foram escolhidos sete condicionantes, a saber: Cavidades Naturais e Potencial Espeleológico, Unidades de Conservação, Terras Indínegas, Comunidades Quilombolas, manchas urbanas/áreas antropizadas e cobertura vegetal/Mata Atlântica, extraídos de mapeamento de uso e ocupação do solo e por fim, dados de Áreas Prioritárias para Conservação da Biodiversidade, todos obtidos a partir de fontes oficiais e em formato shapefile.

Os dados utilizados estão em escala, no mínimo, 1:1.000.000 e no máximo 1:250.000, compatíveis com o nível de análise que se pretende realizar para um estudo de viabilidade.

Os produtos finais estão em datum SIRGAS 2000, e em sistema de coordenadas geográficas. A escala de trabalho final foi de 1.250 .000 em função da 
menor escala entre os dados utilizados. A fim de se poder aplicar uma metodologia cartograficamente correta, optou-se por utilizar a menor escala entre os componentes escolhidos para o estudo, o que pode gerar algumas inconsistências. Com relação a etapas preliminares de planejamento de empreendimentos, como é o caso do presente estudo, pode-se relevar tais inconsistências uma vez que:

O processo de planejamento de um empreendimento é tido como convergente, isto é, que as decisões iniciais são feitas com base em informações pouco precisas, evoluindo progressivamente para decisões fundamentadas com base em informações mais detalhadas, sobretudo em nível técnico e econômico. EGLER, Paulo C. G.

Assim sendo, o rol de dados disponibilizados para consulta, arquivamento e processamento em órgãos públicos foram organizados, categorizados e descritos como será demonstrado adiante.

\subsubsection{Cavidades Naturais e Potencial Espeleológico}

Os dados de Cavidades Naturais e Potencial Espeleológico foram obtidos através do endereço digital do Centro Nacional de Pesquisas e Conservação de Cavernas - CECAV. Os dados referem-se à localização de cavernas e à formações geológicas e conformações litológicas que apresentem potencial para existência de cavernas.

A base de dados do CECAV data de 2004 e conta com o aporte permanente de informações oriundas de outras bases de dados, estudos espeleológicos, material bibliográfico e, especialmente, trabalhos de campo realizados por seus técnicos e analistas ambientais para sua permanente construção.

As Cavidades geoespacializadas são oriundas da integração dos dados de levantamentos de campo realizados pela equipe técnica do CECAV, estudos e pesquisas submetidos ao CECAV/Instituto Chico Mendes de Conservação da Biodiversidade, bibliografia especializada, o Cadastro Nacional de Cavernas do Brasil - CNC, da Sociedade Brasileira de Espeleologia - SBE, Cadastro Nacional de Cavernas - CODEX e REDESPELEO BRASIL. 
A base do CECAV está configurada com sistema de coordenadas geográficas, projeção WGS 84 em escala 1:2.500.000 e data da incorporação dos dados de 30/09/2014, ilustrada na Figura 23.

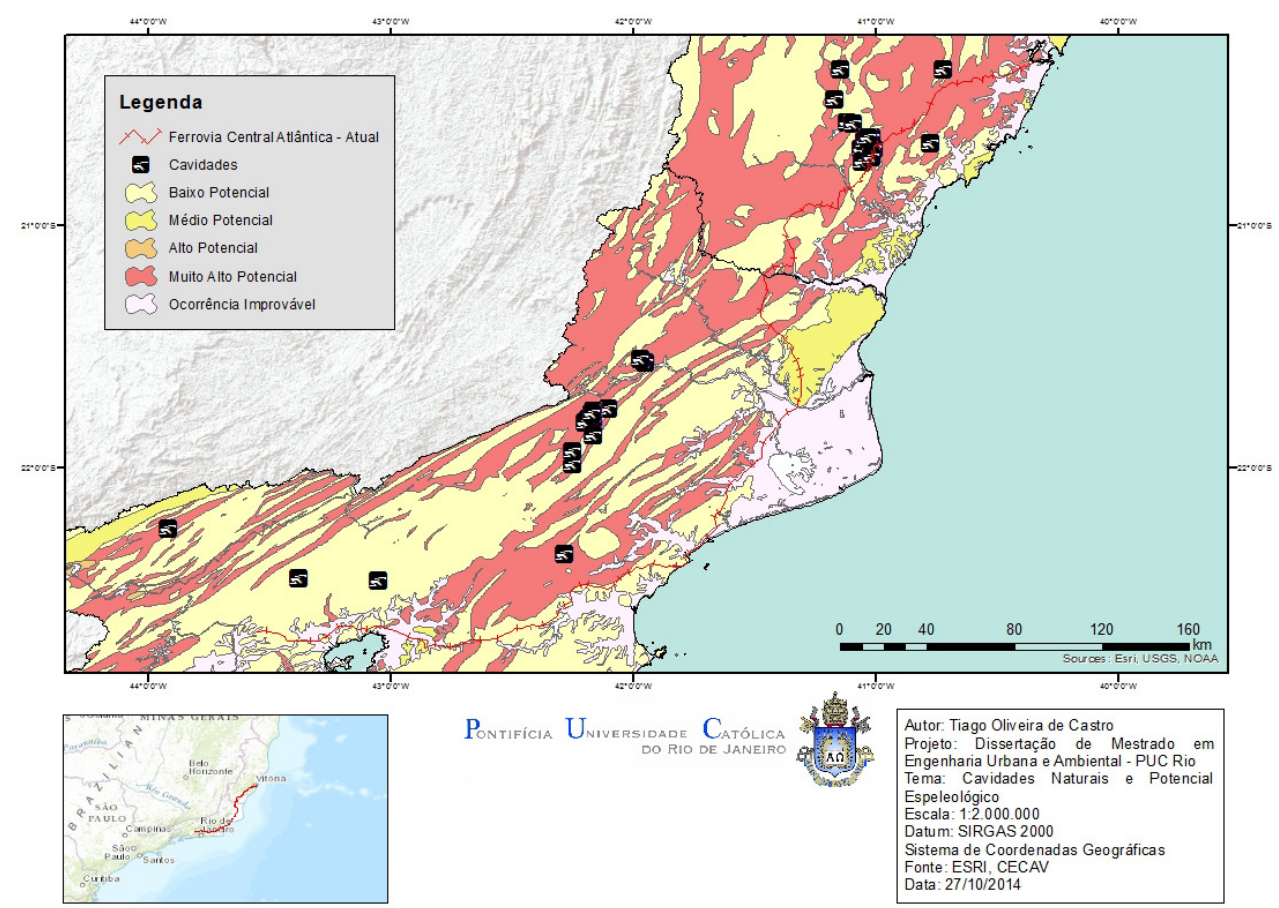

Figura 23 Mapa de Cavidades Naturais e Potencial Espeleológico. Fonte: própria.

\subsubsection{Unidades de Conservação - SNUC}

Os dados dos limites das Unidades de Conservação do Brasil, utilizados no presente estudo, são oriundos da base de dados do Ministério do Meio Ambiente, apresentando escalas que variam de 1:5.000 a 1:100.00 e seu Datum é o SAD 69, datado em 20/04/2012. As UC constantes na base, são aquelas que finalizaram o processo de cadastramento no CNUC (Cadastro Nacional de Unidades de Conservação), estando assim de acordo com a legislação do SNUC (lei $\mathrm{n}^{\circ}$ 9.985/2000).

Um fator que demandou maior atenção no decorrer do desenvolvimento do estudo ora apresentado, foram as Zonas de Amortecimento - ZA que não constam na base de dados do MMA. Assim, as mesmas foram geradas a partir do que estabelece a Resolução CONAMA N 428, 17 de dezembro de 2010 e pode ser apreciadas no mapa da Figura 24 a seguir. 


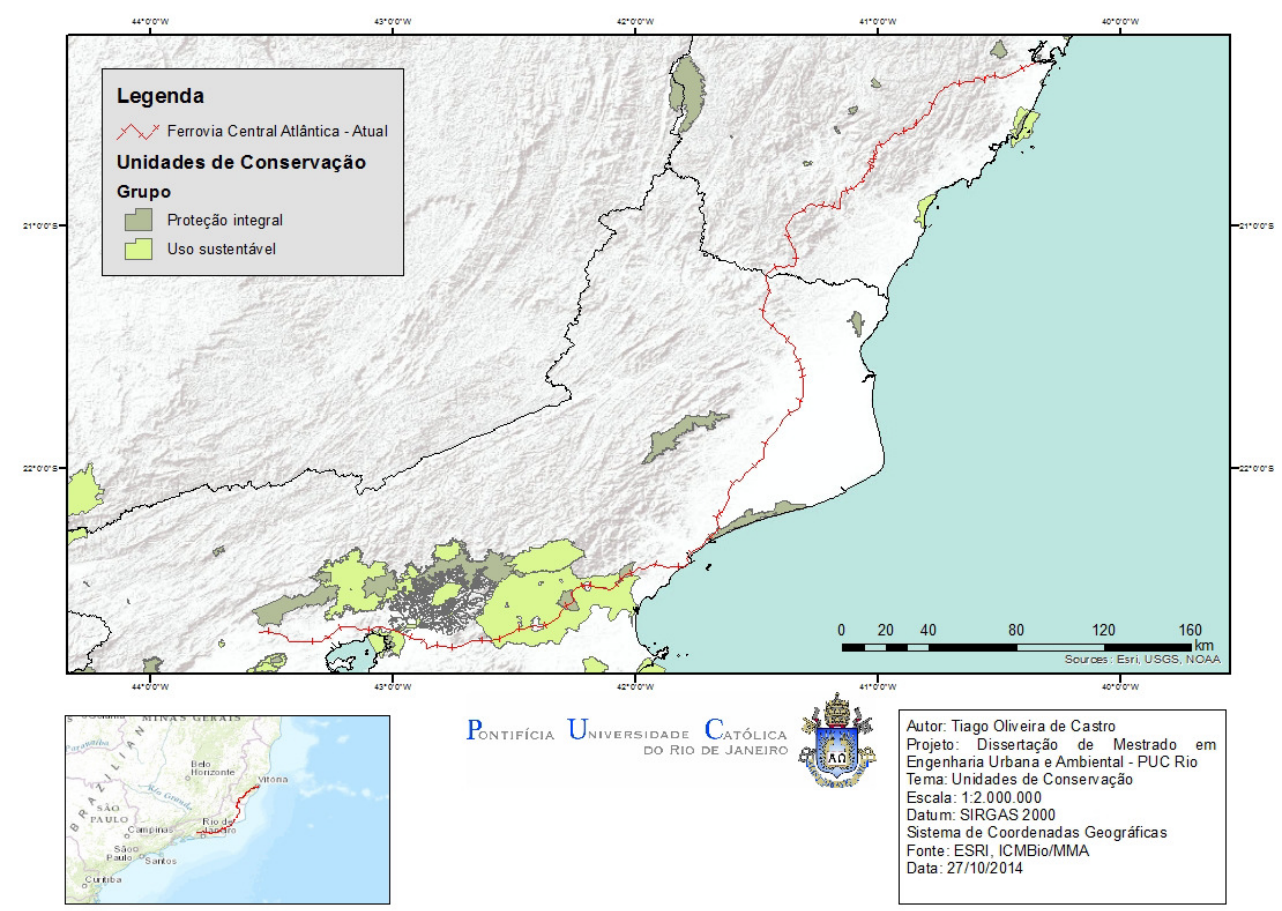

Figura 24: Mapa de Unidades de Conservação. Fonte: própria. Fonte: própria.

\subsubsection{Comunidades Quilombolas}

Com relação às Comunidades Quilombolas, sua espacialização é realizada pelo Instituto Nacional da Colonização e Reforma Agrária - INCRA com apoio da Fundação Palmares e encontra-se disponível na página digital de dados georreferenciados dessa Instituição. Apesar da existência do dado espacial, não foram encontrados maiores detalhes do mesmo, como escala de restituição e data de elaboração, porém o decreto de criação das comunidades consta na tabela de atributos. Tais dados podem ser observados no mapa da Figura 26.

Embora o dado esteja disponível para uso, a ausência de informações como métodos de levantamento, data de elaboração, escala de restituição, dentre outros, faz com que o dado não seja confiável o suficiente para etapas mais avançadas de projeto, o que pode exigir levantamentos em campo, mais onerosos.

\subsubsection{Terras Indígenas}

Os limites de Terras Indígenas foram obtidos na página eletrônica da Fundação Nacional do Índio, porém não apresenta maiores detalhes como escala 
de restituição, data de publicação e atualização. A ausência dessas informações e de metadados consistentes, torna a utilização dos dados pouco confiável para o público em geral, principalmente aquele que busca nas fontes e bases oficiais uma segurança jurídica que possa subsidiar o planejamento de projetos desenvolvidos dentro do território nacional.

Foram consideradas e incluídas no estudo todas as categorias de regularização de Terras Indígenas e que podem ser observadas no mapa da Figura 25 a seguir.

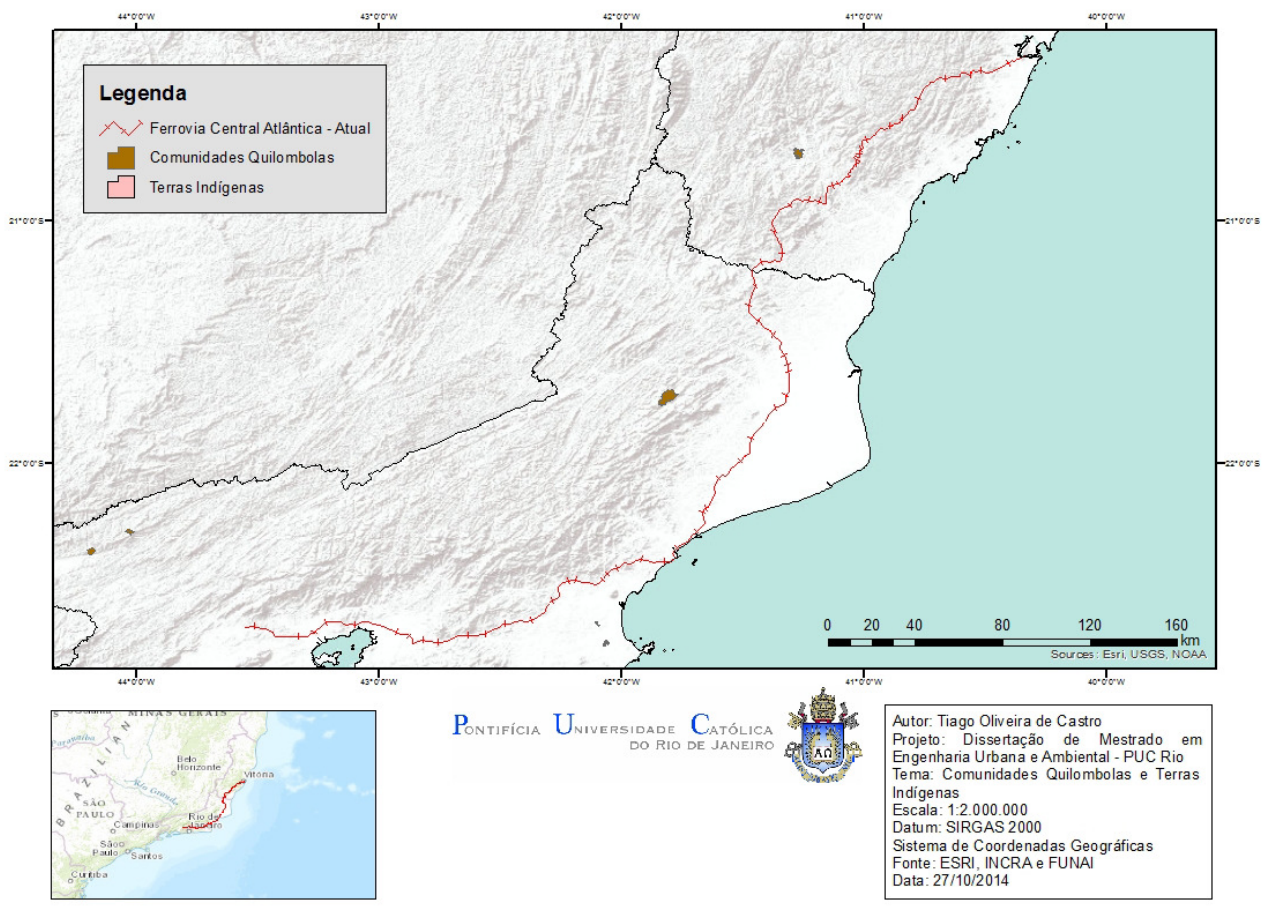

Figura 25: Mapa de Terras Indígenas. Fonte: própria.

\subsubsection{Uso e Cobertura do Solo}

Para delimitação de Áreas Urbanas e florestas segundo a Lei da Mata Atlântica (Lei 11.428/2006) foi utilizado a classificação de uso e ocupação do solo proveniente do Projeto de Conservação e Utilização Sustentável da Diversidade Biológica Brasileira - PROBIO na escala 1:250.000, gerado a partir de imagens do Landsat prioritariamente do ano de 2002. Os dados encontram-se em coordenadas geográficas e Datum SAD 69 e podem ser apreciadas na Figura 26. 
As informações contidas na base de dados, utilizadas no presente estudo estão desatualizadas, como pode ser atestado por conta da sua data de elaboração. Como o uso e cobertura do solo é um dado bastante sensível e em constante alteração, é importante que em etapas mais avançadas de análises novos levantamentos e mapeamentos sejam realizados. Mais uma vez, o dado público não favorece o planejamento, deixando evidente uma lacuna do poder público quanto a políticas de gestão territorial, cabendo ao empreendedor o papel de mapear áreas onde há ausência de informações mais detalhadas do terreno.

Para a delimitação de áreas urbanas, foram categorizadas como tal, o uso e ocupação classificados pelo PROBIO da seguinte maneira:

- Pecuária (Pastagem)

- Formação Pioneira com influência fluvial e/ou lacustre

- Agricultura

- Vegetação Secundária associada a Agropecuária (agricultura, pastagem, pecuária)

- Agropecuária

- Áreas Antrópicas degradadas pela Mineração

- Áreas Antrópicas Indiscriminadas

- Influência Urbana

- Pastagem

- Savana Gramíneo-Lenhosa associada a pecuária 
Para a delimitação de fragmentos florestais contemplados pela Lei da Mata Atlântica, foram categorizadas como tal, o uso e ocupação classificados pelo PROBIO da seguinte maneira:

- Florestamento

- Reflorestamento

- Vegetação Secundária Inicial

- Floresta Estacional

- Floresta Ombrófila Mista

- Floresta Ombrófila Densa

- Savana Gramíneo-Lenhosa

- Floresta Estacional Decidual Montana

- Floresta Estacional Semidecidual das Terras Baixas

- Floresta Estacional Semidecidual Montana

- Floresta Estacional Semidecidual Submontana

- Floresta Estacional Semidecidual Aluvial

- Floresta Ombrófila Aberta Montana

- Floresta Ombrófila Aberta Submontana

- Floresta Ombrófila Densa Alto-Montana 
- Floresta Ombrófila Densa Aluvial

- Floresta Ombrófila Densa das Terras Baixas

- Floresta Ombrófila Densa Montana

- Floresta Ombrófila Submontana

- Floresta Ombrófila Mista Alto-Montana

- Floresta Ombrófila Mista Montana

- Savana Estépica Gramíneo-Lenhosa

- Savana Florestada

- Savana Gramíneo-Lenhosa

- Refúgio Alto-Montano

- Refúgio Montano

- Refúgio Submontano

- Refúgios Vegetacionais Alto-Montano

- Refúgios Vegetacionais Montano

- Refúgios Vegetacionais Submontano 


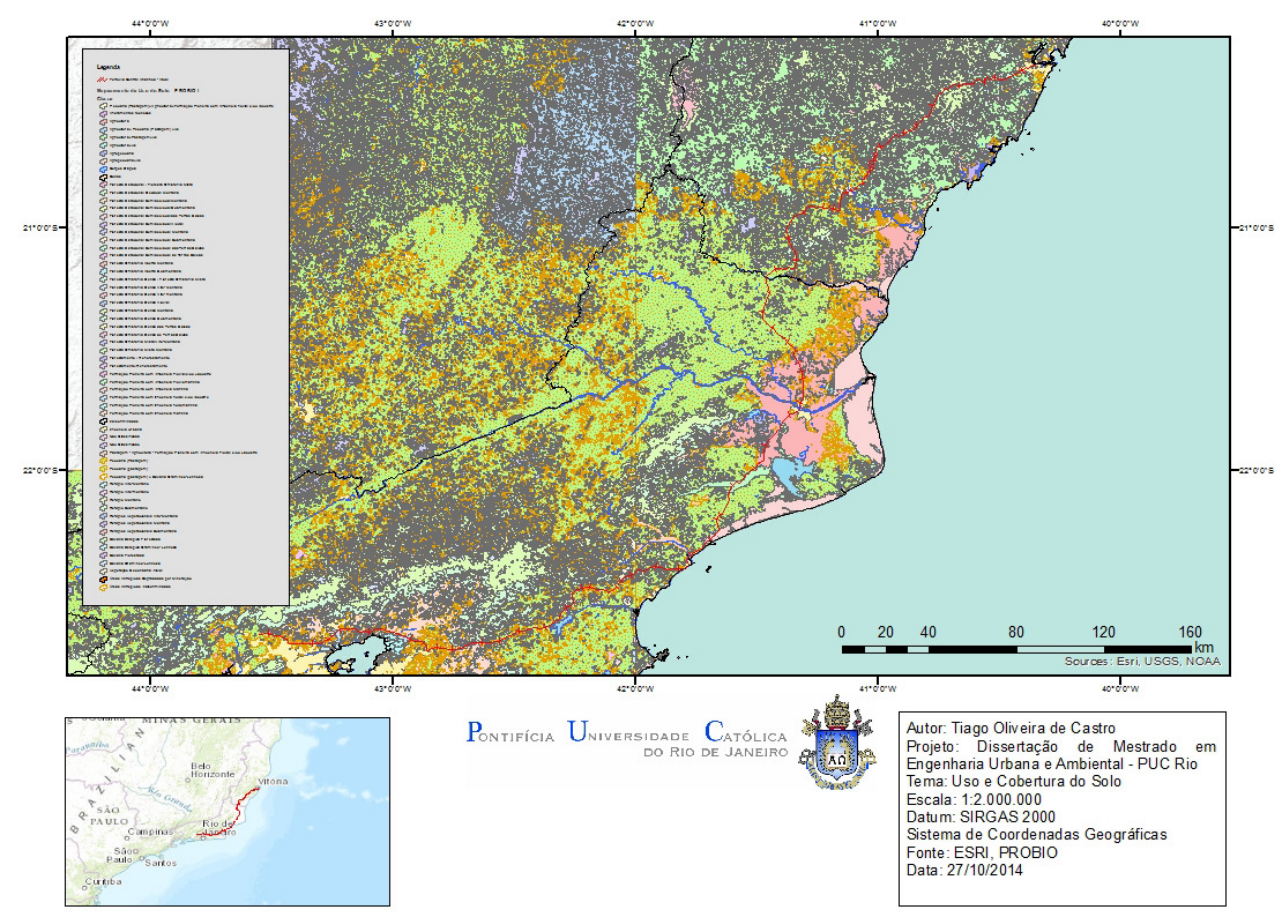

Figura 26: Mapa de Uso e Ocupação do Solo. Fonte: própria.

\subsection{6 Áreas Prioritárias Para Conservação da Biodiversidade}

Por fim, foram obtidos os limites das Áreas Prioritárias para a Conservação da Biodiversidade, junto ao Ministério do Meio Ambiente, uma vez que o Decreto 5.092, de 21 de maio de 2004, preza que o Ministério do Meio Ambiente deve definir as regras para identificação dessas áreas, que podem ser observadas na Figura 27.

São ao todo 900 áreas reconhecidas como "Áreas Prioritárias para a Conservação, Uso Sustentável e Repartição de Benefícios da Biodiversidade Brasileira". Os dados foram elaborados utilizando Datum SAD 69 em escala 1:250.000, a partir do mapeamento de uso e cobertura do solo provenientes do PROBIO. Datam de 2006 e não há divulgação de seu sistema de coordenadas. 


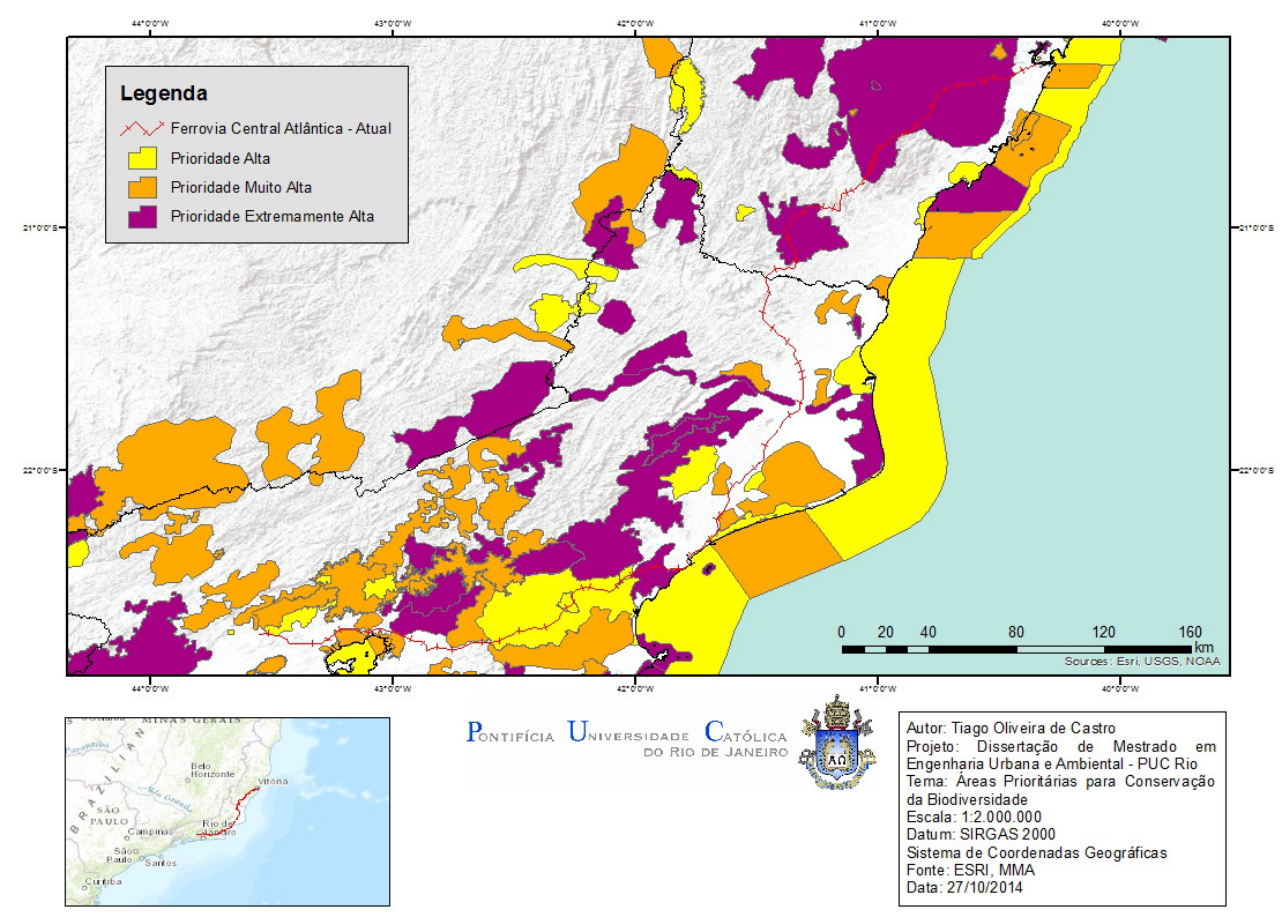

Figura 27: Mapa de Áreas Prioritárias pra Conservação da Biodiversidade. Fonte: própria.

Para a inclusão dos itens mais restritivos relativos a Comunidades Quilombolas, cabe a ressalva de que, para o presente trabalho, não foram realizados trabalhos de campo ou pesquisas mais aprofundadas nas prefeituras que pudessem apontar a existência de comunidades, além das mapeadas pela Fundação Palmares. Porém, um levantamento realizado em sites oficiais para registro de tais comunidades indica que, na ausência do registro e mapeamento, não há remanescentes de quilombos nas cidades. Para o caso de Unidades de Conservação, considerou-se a base oficial do SNUC, mas na medida que o estudo se aprofunda, cabe pesquisa mais abrangente junto às prefeituras municipais. Quanto às áreas urbanas, foram consideradas todas as intervenções antrópicas mapeadas e classificadas constantes na base de dados do PROBIO.

Em suma, os dados foram divididos e valorados conforme apresentado na Tabela 10 a seguir: 
Tabela 10: Dados socioambientais identificados em bases públicas oficiais e seus respectivos valores, definidos para o presente estudo. Fonte: própria.

\begin{tabular}{|c|c|c|}
\hline $\begin{array}{l}\text { Dados socioambientais legais } \\
\text { obtidos em bases públicas } \\
\text { oficiais }\end{array}$ & Subcategoria & Valor \\
\hline Cavidades Naturais & Raio de $250 \mathrm{~m}$ & 5 \\
\hline \multirow{5}{*}{ Potencial Espeleológico } & Baixo potencial & 1 \\
\hline & Médio potencial & 2 \\
\hline & Alto potencial & 4 \\
\hline & Muito alto potencial & 4 \\
\hline & $\begin{array}{l}\text { Ocorrência } \\
\text { Improvável }\end{array}$ & 1 \\
\hline \multirow{3}{*}{ Unidades de Conservação } & Uso Integral & 5 \\
\hline & Uso Sustentável & 3 \\
\hline & NA & 3 \\
\hline $\begin{array}{l}\text { Zona de Amortecimento de } \\
\text { Unidades de Conservação - Uso } \\
\text { Integral }\end{array}$ & Raio de $3 \mathrm{~km}$ & 3 \\
\hline Comunidades Quilombolas & - & 5 \\
\hline $\begin{array}{l}\text { Zona de Amortecimento de } \\
\text { Comunidades Quilombolas }\end{array}$ & Raio de $5 \mathrm{~km}$ & 3 \\
\hline Terras Indígenas & - & 5 \\
\hline $\begin{array}{l}\text { Zona de Amortecimento de } \\
\text { Terras Indígenas }\end{array}$ & Raio de $5 \mathrm{~km}$ & 3 \\
\hline \multirow{11}{*}{ Mata Atlântica } & Florestamento & \multirow{11}{*}{4} \\
\hline & Reflorestamento & \\
\hline & $\begin{array}{l}\text { Vegetação } \\
\text { Secundária Inicial }\end{array}$ & \\
\hline & Floresta Estacional & \\
\hline & $\begin{array}{l}\text { Floresta Ombrófila } \\
\text { Mista }\end{array}$ & \\
\hline & $\begin{array}{l}\text { Floresta Ombrófila } \\
\text { Densa }\end{array}$ & \\
\hline & $\begin{array}{l}\text { Savana Gramíneo- } \\
\text { Lenhosa }\end{array}$ & \\
\hline & $\begin{array}{l}\text { Floresta Estacional } \\
\text { Decidual Montana }\end{array}$ & \\
\hline & $\begin{array}{l}\text { Floresta Estacional } \\
\text { Semidecidual das } \\
\text { Terras Baixas }\end{array}$ & \\
\hline & $\begin{array}{l}\text { Floresta Estacional } \\
\text { Semidecidual } \\
\text { Montana }\end{array}$ & \\
\hline & $\begin{array}{l}\text { Floresta Estacional } \\
\text { Semidecidual } \\
\text { Submontana } \\
\end{array}$ & \\
\hline
\end{tabular}




\begin{tabular}{|c|c|}
\hline $\begin{array}{l}\text { Floresta Estacional } \\
\text { Semidecidual Aluvial }\end{array}$ & \\
\hline $\begin{array}{l}\text { Floresta Ombrófila } \\
\text { Aberta Montana }\end{array}$ & \\
\hline $\begin{array}{l}\text { Floresta Ombrófila } \\
\text { Aberta Submontana }\end{array}$ & \\
\hline $\begin{array}{l}\text { Floresta Ombrófila } \\
\text { Densa Alto-Montana }\end{array}$ & \\
\hline $\begin{array}{l}\text { Floresta Ombrófila } \\
\text { Densa Aluvial }\end{array}$ & \\
\hline $\begin{array}{l}\text { Floresta Ombrófila } \\
\text { Densa das Terras } \\
\text { Baixas } \\
\end{array}$ & \\
\hline $\begin{array}{l}\text { Floresta Ombrófila } \\
\text { Densa Montana }\end{array}$ & \\
\hline $\begin{array}{l}\text { Floresta Ombrófila } \\
\text { Submontana }\end{array}$ & \\
\hline $\begin{array}{l}\text { Floresta Ombrófila } \\
\text { Mista Alto-Montana }\end{array}$ & \\
\hline $\begin{array}{l}\text { Floresta Ombrófila } \\
\text { Mista Montana } \\
\end{array}$ & \\
\hline $\begin{array}{l}\text { Savana Estépica } \\
\text { Gramíneo-Lenhosa }\end{array}$ & \\
\hline Savana Florestada & \\
\hline $\begin{array}{l}\text { Savana Gramíneo- } \\
\text { Lenhosa }\end{array}$ & \\
\hline $\begin{array}{l}\text { Refúgio Alto- } \\
\text { Montano }\end{array}$ & \\
\hline Refúgio Montano & \\
\hline Refúgio Submontano & \\
\hline $\begin{array}{l}\text { Refúgios } \\
\text { Vegetacionais Alto- } \\
\text { Montano }\end{array}$ & \\
\hline $\begin{array}{l}\text { Refúgios } \\
\text { Vegetacionais } \\
\text { Montano } \\
\end{array}$ & \\
\hline $\begin{array}{l}\text { Refúgios } \\
\text { Vegetacionais } \\
\text { Submontano } \\
\end{array}$ & \\
\hline Pecuária (Pastagem) & \\
\hline $\begin{array}{l}\text { Formação Pioneira } \\
\text { com influência } \\
\text { fluvial e/ou lacustre }\end{array}$ & \\
\hline Agricultura & \\
\hline
\end{tabular}




\begin{tabular}{|l|l|} 
& $\begin{array}{l}\text { Vegetação } \\
\text { Secundária associada } \\
\text { a Agropecuária } \\
\text { (agricultura, } \\
\text { pastagem, pecuária) }\end{array}$ \\
\hline & Agropecuária \\
\hline & $\begin{array}{l}\text { Áreas Antrópicas } \\
\text { degradadas pela } \\
\text { Mineração }\end{array}$ \\
\hline & $\begin{array}{l}\text { Áreas Antrópicas } \\
\text { Indiscriminadas }\end{array}$ \\
\hline & Influência Urbana \\
\hline & Pastagem \\
\hline & $\begin{array}{l}\text { Savana Gramíneo- } \\
\text { Lenhosa associada a } \\
\text { pecuária }\end{array}$ \\
\hline Área Prioritária para & \\
Conservação da Biodiversidade & \\
\hline
\end{tabular}

\subsection{Zoneamento Ambiental de Restrições Socioambientais Legais - Dados Vetoriais}

O Zoneamento Ambiental de Restrições Legais será apresentado neste ítem, por meio de mapas gerados a partir da manipulação e processamento de dados vetoriais. No total foram elaborados três mapas, através da aplicação de dois modelos: "Soma", que após classificação resultou em dois mapas e "Média Ponderada". Portanto, como produto da aplicação das metodologias citadas, podem ser apreciados 3 mapas diferentes, tendo como subsídio para sua elaboração os mesmos dados de entrada para todos.

O cálculo do modelo de soma, que pode ser visto na Equação 2, adicionou os valores presentes nos atributos de cada feição criada para tal finalidade, sem diferenciar a importância relativa de cada variável socioambiental.

[Cavidades $]+[$ PEspeleo $]+[$ APPC $]+[$ UOS_MA $]+[$ UCS $]+[$ TIndigenas $]$ $+[$ CQuilombo] $+[$ Areas Urb]

Equação 2: Soma dos valores presentes na tabela de atributos dos dados de restrições socioambientais legais obtidas em bases públicas oficiais.

Sendo: 
- Cavidades - Valor estabelecido para Cavidades Naturais e seus respectivos raios de $250 \mathrm{~m}$.

- PEspeleo - Valor estabelecido para Potencial Espeleológico.

- APPC - Valor estabelecido para Áreas Prioritárias para Conservação da Biodiversidade.

- UOS_MA - Valor estabelecido para Mata Atlântica.

- UCS - Valor estabelecido para Unidades de Conservação e suas respectivas Zonas de Amortecimento de $3 \mathrm{~km}$.

- TIndigenas - Valor estabelecido para Terras Indígenas e suas respectivas Zonas de Amortecimento de $5 \mathrm{~km}$.

- CQuilombo - Valor estabelecido para Comunidades Quilombolas e suas respectivas Zonas de Amortecimento de $5 \mathrm{~km}$.

- Areas_Urb - Valor estabelecido para Áreas Urbanas ou Antropizadas.

Já para o modelo "Média Ponderada" foi realizado o seguinte cálculo visto na Equação 3 a seguir:

$[$ Cavidades $] * 0.12+[$ PEspeleo $] * 0.12+[$ APPC $] * 0.12+[$ UOS_MA $] * 0.12+$
$[$ UCS $] * 0.12+[$ TIndigenas $] * 0.12+[$ CQuilombo $] * 0.12+[$ Areas_Urb $] * 0.12$ Equação 3: Média ponderada dos valores presentes na tabela de atributos dos dados de restrições socioambientais legais obtidas em bases públicas oficiais.

Sendo:

- Cavidades - Valor estabelecido para Cavidades Naturais e seus respectivos raios de $250 \mathrm{~m}$. 
- PEspeleo - Valor estabelecido para Potencial Espeleológico.

- APPC - Valor estabelecido para Áreas Prioritárias para Conservação da Biodiversidade.

- UOS_MA - Valor estabelecido para Mata Atlântica.

- UCS - Valor estabelecido para Unidades de Conservação e suas respectivas Zonas de Amortecimento de $3 \mathrm{~km}$.

- TIndigenas - Valor estabelecido para Terras Indígenas e suas respectivas Zonas de Amortecimento de 5km.

- CQuilombo - Valor estabelecido para Comunidades Quilombolas e suas respectivas Zonas de Amortecimento de 5km.

- Areas_Urb - Valor estabelecido para Áreas Urbanas ou Antropizadas.

E os pesos atribuídos para cada aspecto sendo igual a 12, valor que multiplicado por 8 chega a aproximadamente 100 .

\subsubsection{Modelo "Soma" classificado em intervalos iguais}

Mapa elaborado a partir do modelo "Soma", onde os valores foram classificados em intervalos iguais. A classificação por intervalos iguais divide a extensão dos valores dos atributos em subclasses equalizadas. Isso permite a especificação do número de intervalos, que no caso em questão foi de 5 intervalos e assim é determinada uma quebra para cada um deles, baseada na extensão total dos valores dos atributos.

A classificação por intervalos iguais é melhor aplicada a extensões de valores familiares, como percentual e temperatura. Esse método enfatiza o valor e a importância de um atributo frente aos demais. 
Dessa maneira, o mapa elaborado para esse modelo não apresentou restrições legais, mesmo para os valores mais altos encontrados após a soma de atributos das camadas que se sobrepuserem umas as outras. O resultado então, se traduziu no mapa conforme as categorias de restrições determinadas em etapa pretérita e pode ser apreciado a seguirna Figura 28.

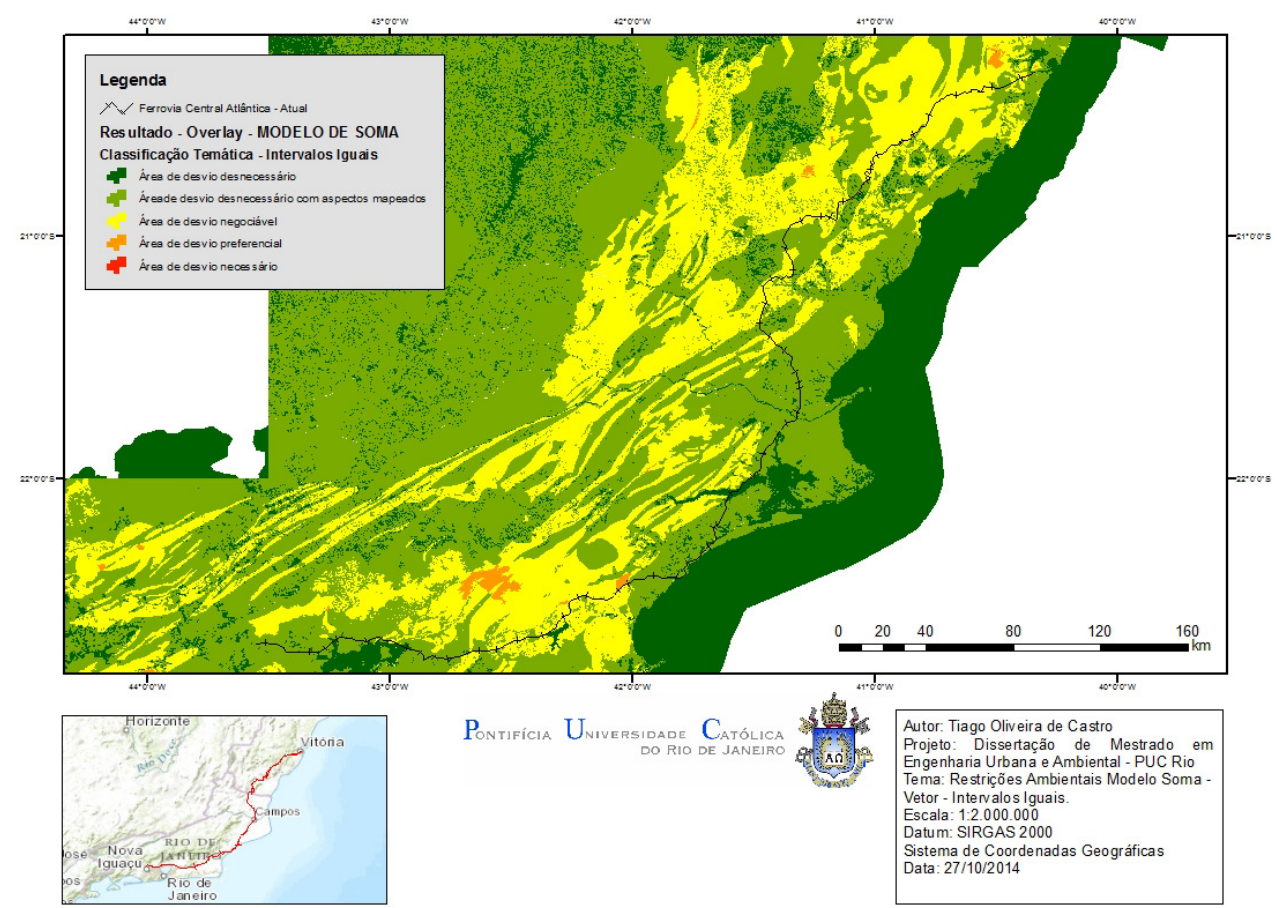

Figura 28: Mapa do Modelo "Soma" classificado em intervalos iguais. Fonte: própria.

No presente modelo apresentado, áreas restritas como Unidades de Conservação de Uso Integral, por exemplo, não foram representadas, o que para o planejamento ambiental torna esse tipo de zoneamento pouco fiel à realidade conhecida e não muito útil.

O modelo "Soma", classificado em intervalos iguais, portanto não obteve êxito em retratar a realidade de maneira a dar segurança tanto ao empreendedor quanto ao gestor do território, por sua incapaciade de identificação das áreas restritas principalmente, além de áreas com diferentes níveis de restições de forma confiável. 


\subsubsection{Modelo "Soma" classificado em quebras naturais}

O modelo "Soma" classificado por quebras naturais é baseado em agrupamentos estabelecidos naturalmente entre os valores presentes nos atributos dos dados espaciais. As quebras de classe são definidas pela melhor similaridade na composição de um agrupamento para valores semelhantes e acentuação das diferenças entre as classes. As camadas são divididas em classes cujos limites são estabelecidos onde existe uma grande diferença relativa nos valores dos dados.

A classificação por quebras naturais são baseadas em dados específicos e não são bons indicadores na comparação de múltiplos mapas, construídos a partir de diferentes informações subjacentes.

Dessa maneira, o mapa elaborado para esse modelo, apesar de apresentar restrições legais e sugerir zonas onde as ações antrópicas do setor produtivo devem ser desencorajadas ou não realizadas, não representou todas as restrições de uso do solo conforme identificado nos dados espaciais socioambientais legais. Assim como no modelo "Soma" com classificação de intervalos iguais, as Unidade de Conservação de uso integral, ou Terras Indígenas não foram retratadas. Assim, o resultado se traduziu no mapa conforme as categorias de restrições determinadas em etapa pretérita e pode ser apreciado a seguir, na Figura 29. 


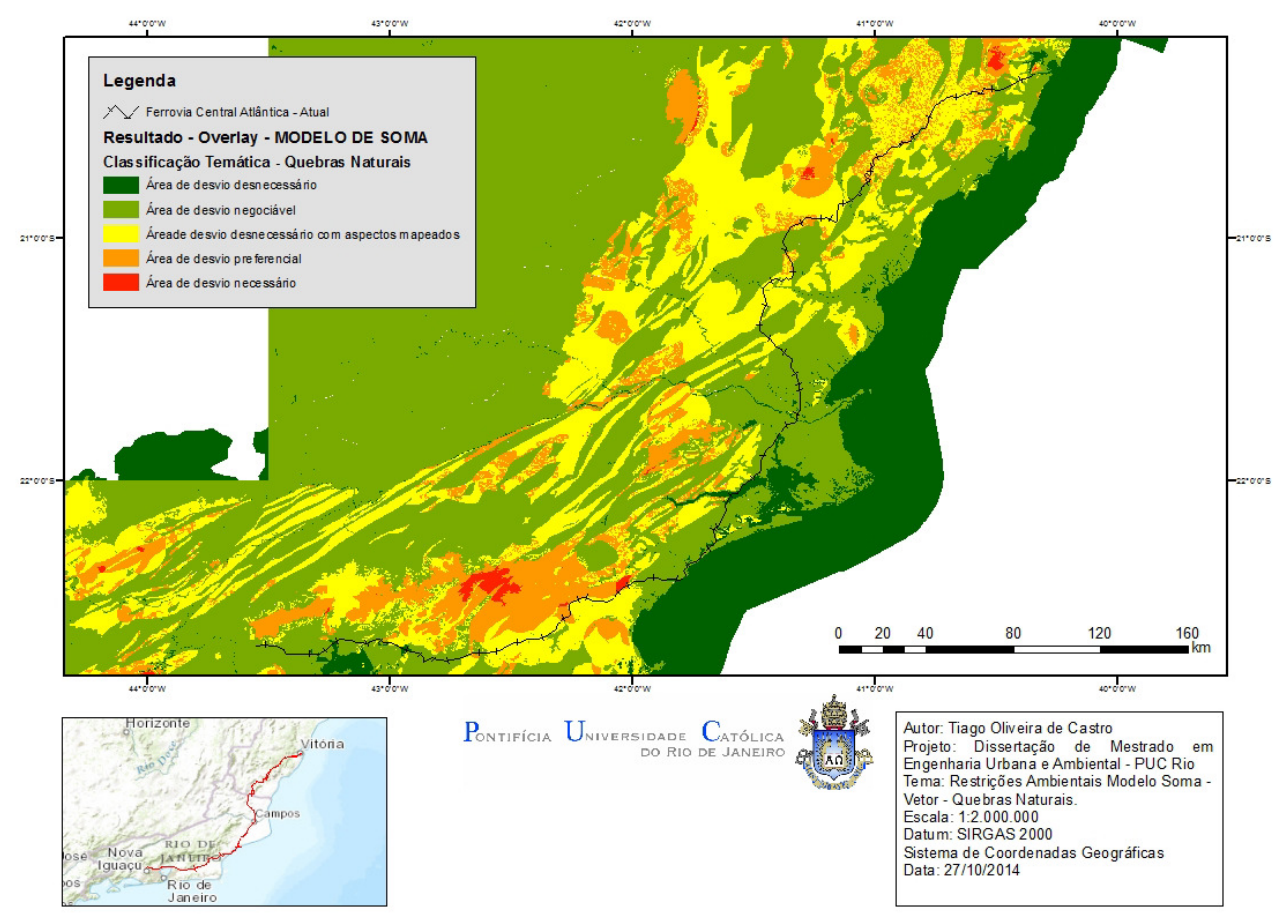

Figura 29: Mapa do Modelo "Soma" classificado em quebras naturais. Fonte: própria.

Porém, ainda que esse modelo não atenda ao propósito de refletir a realidade do uso do solo no recorte espacial estudado, ele ainda se saiu melhor na comparação com o modelo "Soma" por classificação de intervalos iguais. Mesmo assim não se mostrou um produto útil para o zoneamento pretendido, não representando um aspecto nevral para o planejamento territorial pretendido: as principais áreas de uso restrito identificadas na legislação.

\subsubsection{Modelo "Ponderado" com atribuição equalitária de pesos}

O modelo "Ponderado", como já explicado no presente trabalho, é resultado da atribuição de pesos aos valores pré-estabelecidos para cada uma das restrições ambientais legais utilizadas para compor o zoneamento pretendido. No estudo de caso, foram atribuídos pesos iguais, para cada uma das variáveis ou restrições socioambientais legais.

Aplicada a equação de média ponderada com os devidos pesos e valores, o produto desenvolvido se traduz no zoneamento de retrições socioambientais legais que pode ser apreciado no mapa a seguir, na Figura 30. 


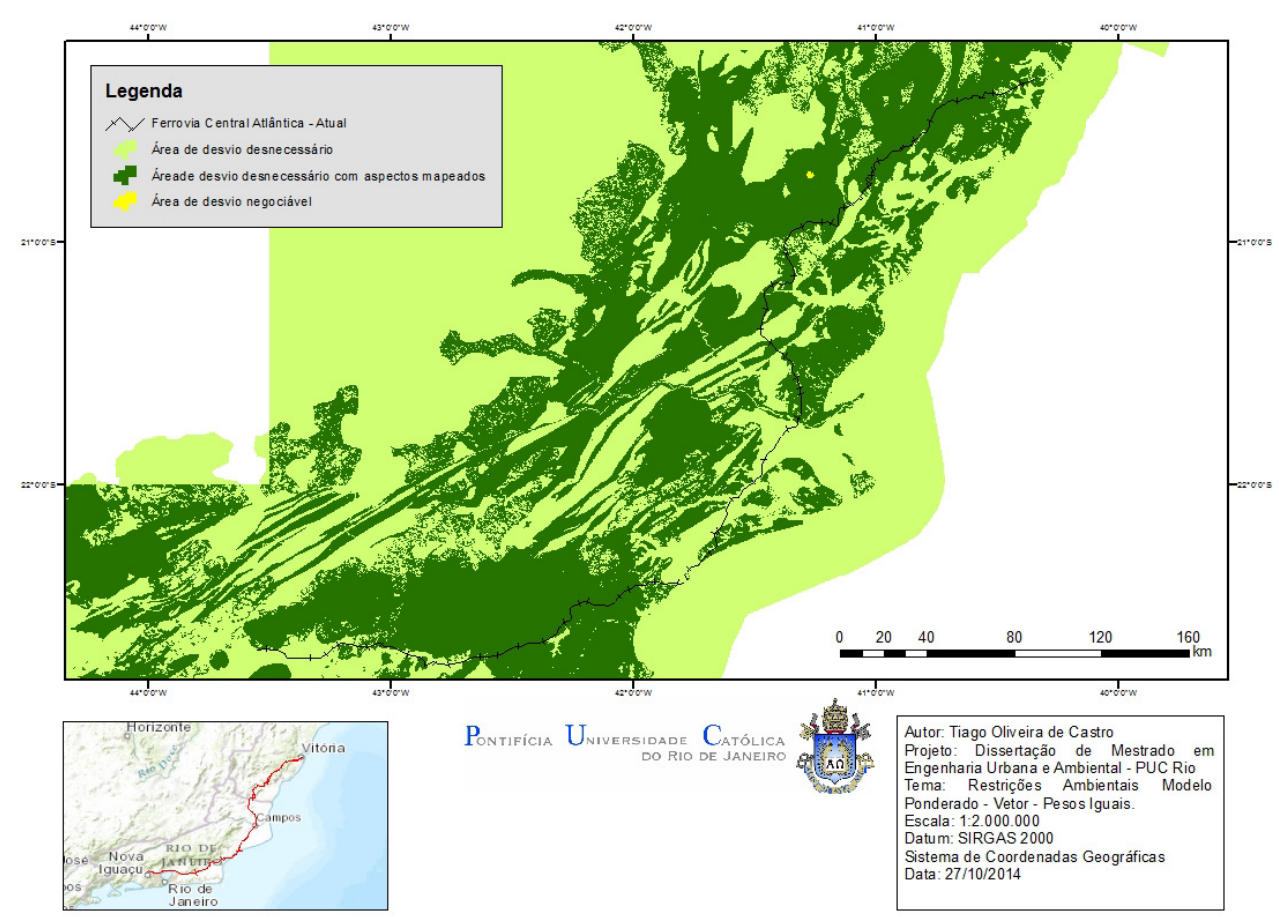

Figura 30: Mapa do Modelo "Ponderado" com atribuição equalitária de pesos. Fonte: própria.

O resultado encontrado, como nos outros casos apresentados até aqui, não foi capaz de retratar a realidade das restrições socioambientais legais, podendo ser descartado como indicador de áreas mais ou menos propensas à execução de empreendimentos, em espacial as ferrovias.

No modelo "Ponderado" proposto utilizando dados vetoriais as zonas ou classes apresentadas são apenas três e nenhum deles representou restrições, o que sabe-se ser uma situação falsa, quando comparada à realidade.

\subsection{Zoneamento Ambiental de Restrições Socioambientais Legais - Dados Raster}

O Zoneamento Ambiental de Restrições Legais será apresentado neste ítem, por meio de mapas gerados a partir da manipulação e processamento de dados raster. No total foram elaborados cinco mapas, através da aplicação de dois modelos: "Soma Ponderada", que após classificação e atribuição de pesos resultou em dois mapas e "Média Ponderada", com 3 mapas gerados após classificação e atribuição de pesos, com adoção de matriz 1 para 5 para 1 , mais adequada para o caso em questão, devido ao mesmo apresentar cinco classes de restrições. 
Portanto, como produto da aplicação das metodologias citadas, podem ser apreciados 5 mapas diferentes, tendo como subsídio para sua elaboração os mesmos dados de entrada para todos.

\subsubsection{Modelo "Soma Ponderada" com atribuição equalitária de pesos}

Para o modelo "Soma Ponderada" ora apresentado, foi atribuído peso 1 para todos as restrições socioambientais legais identificadas. Assim cada uma dessas restrições foi multiplicada pelo peso estabelecido, somadas e sobrepostas.

A extensão dos valores das restrições multiplicadas pelo peso e somadas variou de um valor mínimo 9, representando o menor nível de restição, até um valor máximo 26, representando o maior nível de restrição.

Como resultado da aplicação desse modelo, tem-se o mapa abaixo, na Figura 31.

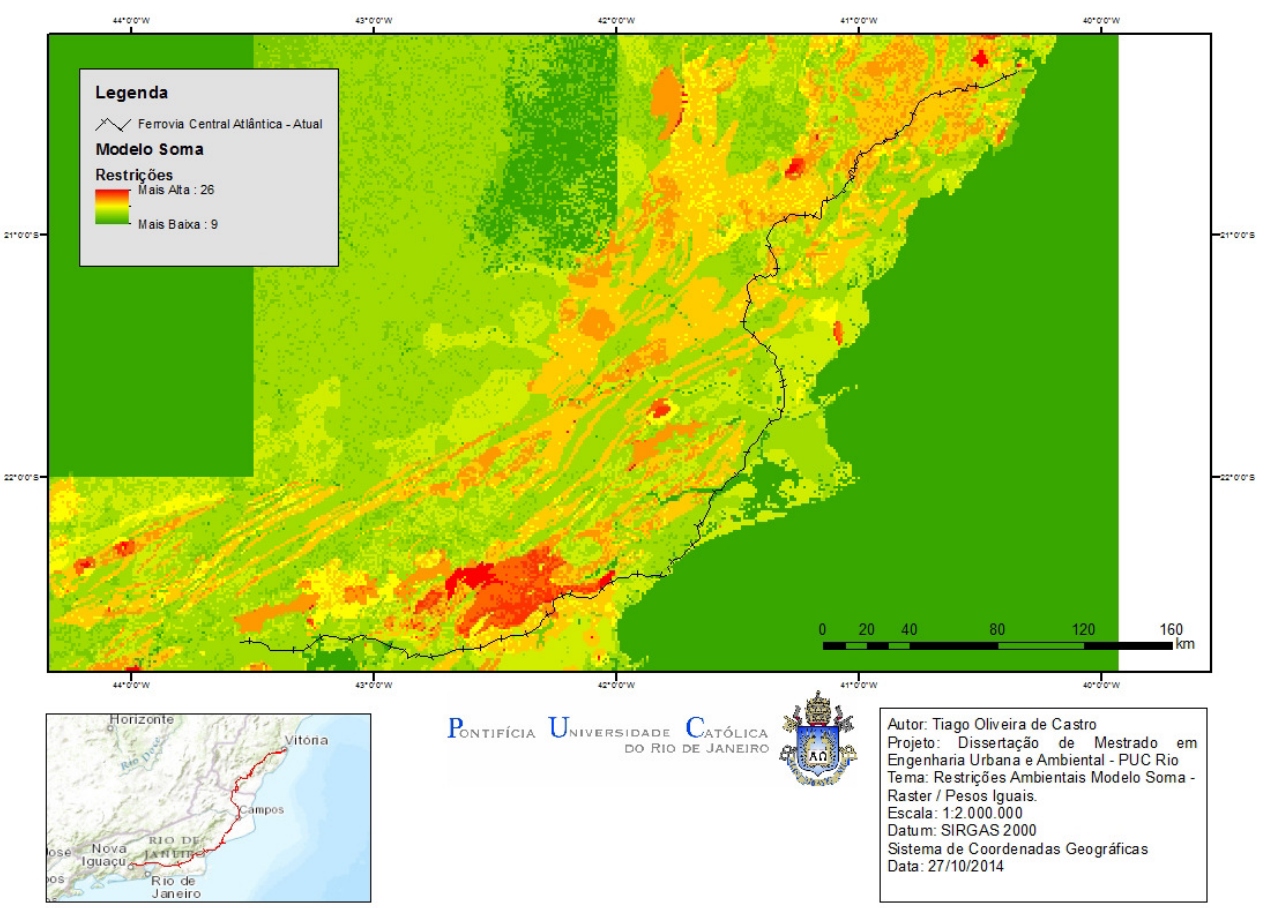

Figura 31: Mapa do Modelo "Soma Ponderada" com atribuição equalitária de pesos. Fonte: própria. 
O mapa apresentado tem, a princípio, uma boa correlação com a realidade, porém, assim como os modelos apresentados até aqui, não conseguiu traduzir as restrições existentes ao uso do solo conforme trata a legislação.

O resultado do zoneamento se deu através de uma distribuição gradativa crescente, onde as cores mais quentes traduzem maiores restrições. Percebe-se que esse modelo não foi capaz de atribuir a porções do espaço um estatus de restrição adequado. Prova disso é o Parque Nacional da Restinga de Jurubatiba estar representado por cores mais frias, o que significa menor restrição de uso e ocupação.

\subsubsection{Modelo "Soma Ponderada" com atribuição de pesos diferenciados para as restrições socioambientais legais}

Para o modelo em questão, foram atribuidos pesos diferentes a fim de se salientar algumas restrições que, pela experiência, são mais complexas e exigem maior esforço para serem vencidas, quando há possibiliade de negociação. Podese apreciar na Tabela 11 a seguir os pesos atribuídos a cada restrição considerada.

Tabela 11: Pesos atribuídos às restrições socioambientais legais. Fonte: própria.

\begin{tabular}{|l|c|}
\hline Aspecto/Restrição Socioambiental Legal & Peso \\
\hline Mata Atlântica & 2 \\
\hline Áreas Urbanas/Antropizadas & 2 \\
\hline Terras Indígenas & 3 \\
\hline Zona de Amortecimento de Terras Indígenas & 1 \\
\hline Comunidades Quilombolas & 3 \\
\hline Zona de Amortecimento de Comunidades & 1 \\
\hline Quilombolas & 3 \\
\hline Cavidade Naturais & 2 \\
\hline Potencial Espeleológico & 1 \\
\hline Áreas Prioritárias para Conservação da Biodiversidade & 4 \\
\hline Unidades de Conservação & 1 \\
\hline Zona de Amortecimento de Unidades de Conservação & \\
\hline
\end{tabular}

Considerados os pesos, multiplicando-os aos valores estabelecidos para as restrições e posteriormente somando esses resultados através de sobreposição de camadas, o resultado foi uma extensão de valores que vão desde o mínimo de 21 
para áreas com menores níveis de restrições até o máximo de 66 para áreas com maiores níveis de restrições e o resultado pode ser observado na Figura 32.

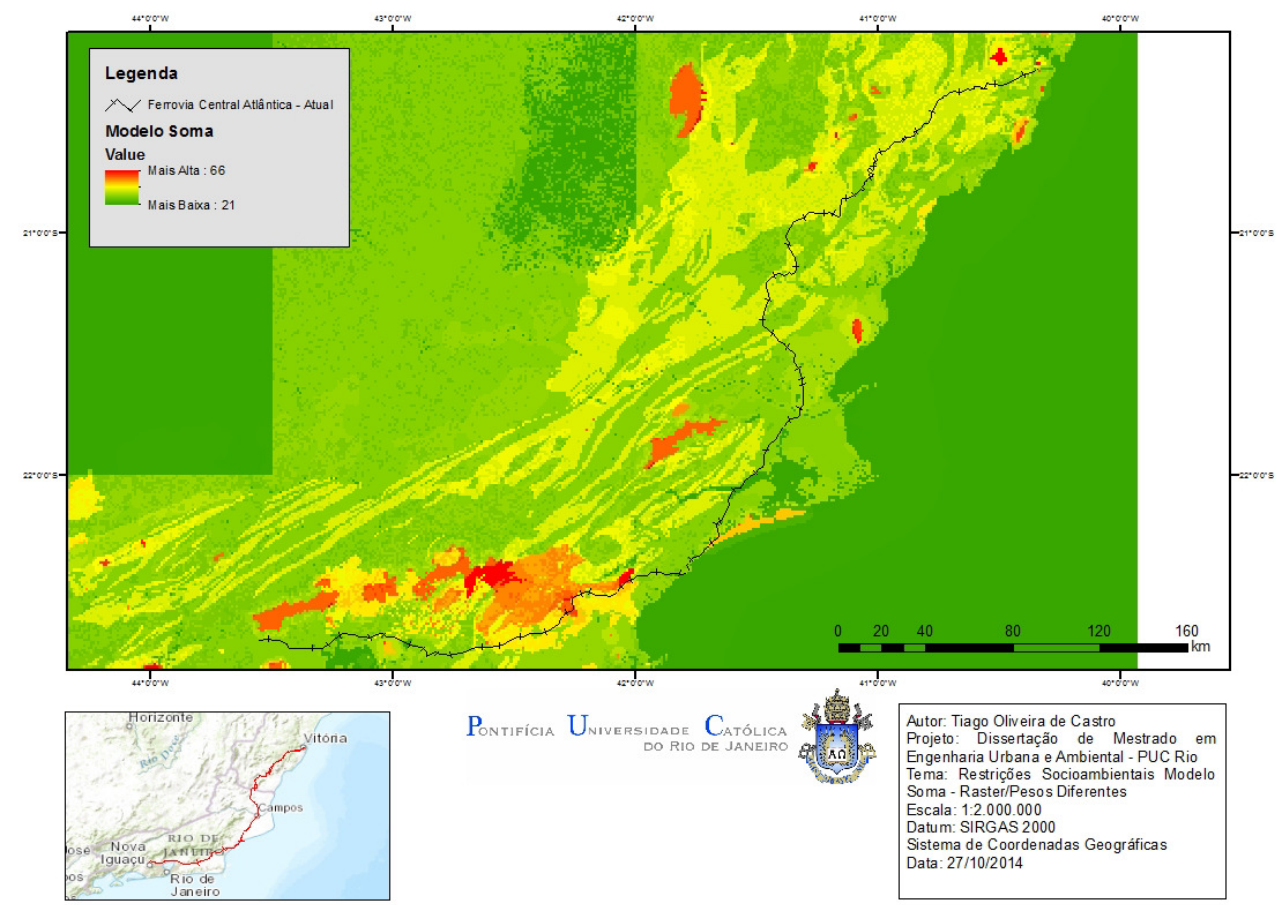

Figura 32: Mapa do Modelo "Soma Ponderada" com atribuição de pesos diferenciados para as restrições socioambientais legais. Fonte: própria.

O mapa apresentado tem, a princípio, uma boa correlação com a realidade pouco se diferenciando do modelo em que os pesos atribuídos tiveram o mesmo valor. No entanto, assim como os modelos apresentados até aqui, não conseguiu traduzir as restrições existentes ao uso do solo conforme trata a legislação.

Assim como o modelo apresentado anteriormente, a diferença está no range que sai de um parâmetro mínimo com valor mais alto, bem como é mais alto o valor máximo. Dessa forma, o resultado do zoneamento se deu através de uma distribuição gradativa crescente, onde as cores mais quentes traduzem maiores restrições. Percebe-se que esse modelo não foi capaz de atribuir a porções do espaço um estatus de restrição adequado. Prova disso é o Parque Nacional da Restinga de Jurubatiba estar representado por cores mais frias, o que significa menor restrição de uso e ocupação. 


\subsubsection{Modelo "Média Ponderada" com atribuição equalitária de pesos e adoção de áreas restritas para pixels de valor 5}

Para execução de modelos de processamento em dados raster, é possível, diferentemente do que ocorre para dados vetoriais, estabelecer áreas restritas, que independente de pesos e valores não são computadas na ponderação.

Isso é especialmente vantajoso quando se sabe de antemão que alguns aspectos que compõe a análise espacial são clara e objetivamente restritos, tornando regra a exclusão desses aspectos na equação da média ponderada. Além disso, o resultado do modelo aplicado dividiu o zoneamento em 3 categorias, chamadas de "Áreas Restritas”, “Áreas sem Restrições” e “Áreas com restrições negociáveis" e isso é válido para todos os modelos que serão apresentados adiante.

Portanto, logo de início, fica clara a vantagem do modelo "Média Ponderada" frente aos demais analisados e testados até aqui. Entretanto, deve-se tomar cuidado com as restrições adotadas, uma vez que os resultados alcançados podem apontar a inviabilidade de se utilizar numerosas parcelas do terreno.

Para o caso em questão, as restrições socioambientais com valor 5 foram consideradas zonas restritas e o resultado segue adiante, na Figura 33. 


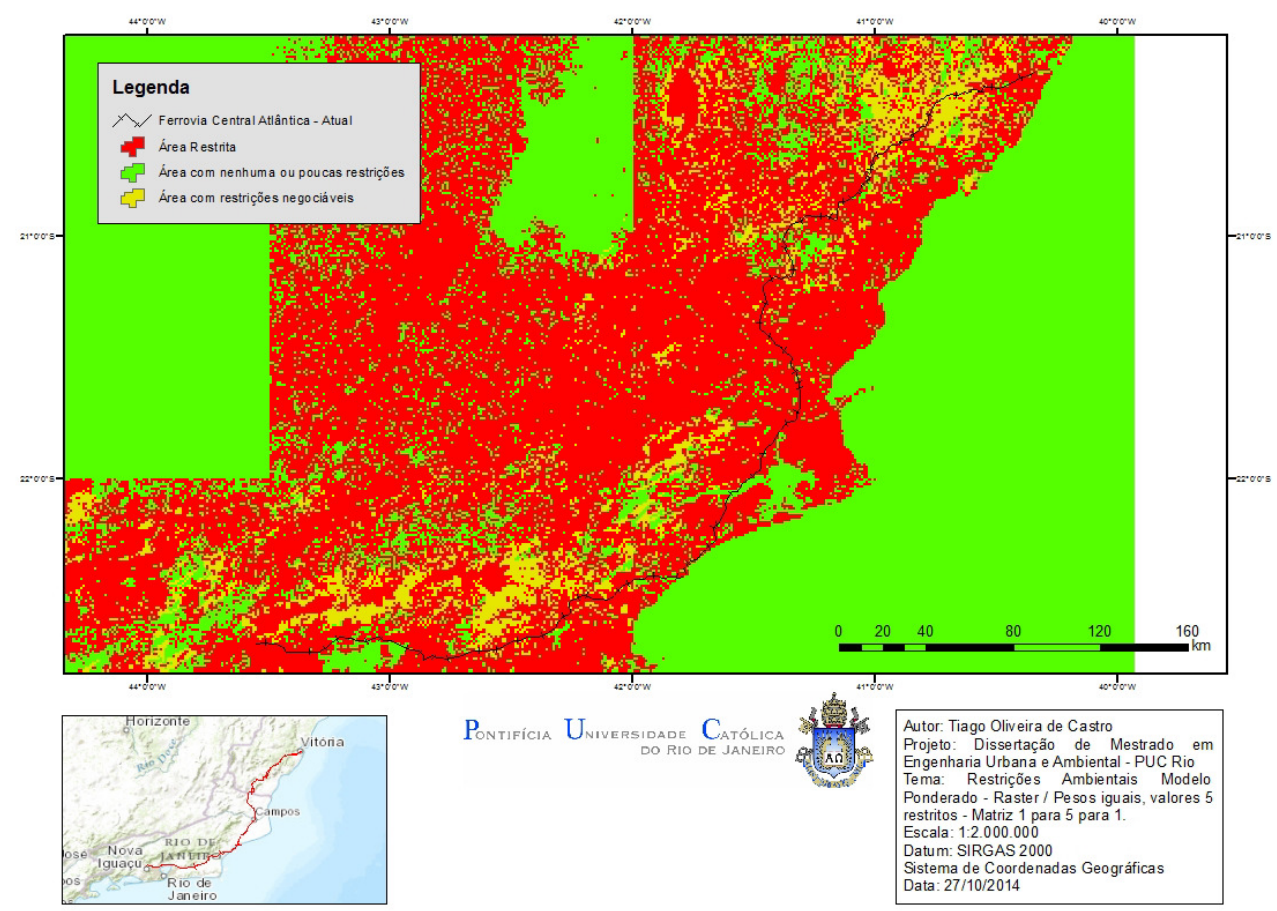

Figura 33: Mapa do Modelo "Média Ponderada" com atribuição equalitária de pesos e adoção de áreas restritas para pixels de valor 5. Fonte: própria.

Conforme dito acima, adotar como regra que todo pixel de valor 5 é igual a uma área objetivamente restita não apresenta um resultado eficiente, dado que aponta para uma inviabilidade quase total de uso do solo no recorte espacial estudado. O modelo, portanto, está aquém do esperado e não é um bom indicador para o planejamento.

\subsubsection{Modelo "Média Ponderada" com atribuição equalitária de pesos e adoção de áreas restritas para pixels de valor 5 , exceto os de categoria Áreas Urbanas/Áreas Antropizadas}

O zoneamento realizado através do presente modelo é uma alternativa ao que foi realizado no anterior. O princípio baseia-se nos mesmos pressupostos, onde a regra para pixels com valor 5 é de restrição. A diferença aqui fica a cargo de uma excessão para àqueles categorizados como Áreas Urbanas/Áreas Antropizadas, considerados assim na ponderação com as demais categorias e seus respectivos valores.

O resultado se aproxima bastante da realidade, tornando-se um modelo de zoneamento com aplicação prática e que dá efetivo respaldo à tomada de decisão 
quanto às restrições de uso e ocupação do solo sob a ótica da legislação ambiental, como pode ser notado na Figura 34 adiante.

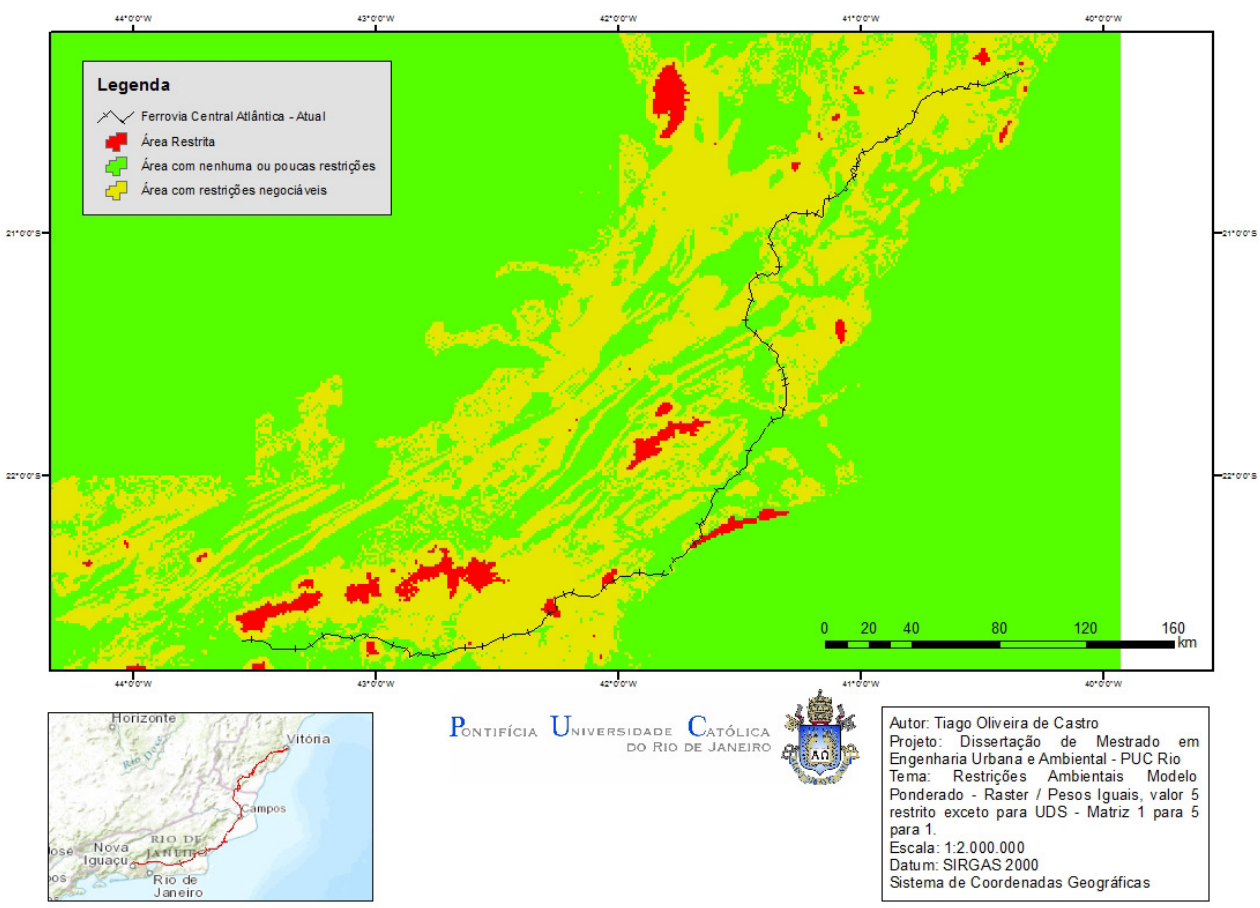

Figura 34: Mapa do Modelo "Média Ponderada" com atribuição equalitária de pesos e adoção de áreas restritas para pixels de valor 5, exceto os de categoria Áreas Urbanas/Áreas Antropizadas. Fonte: própria.

\subsubsection{Modelo "Média Ponderada" com atribuição de pesos} diferenciados para as restrições socioambientais legais e adoção de áreas restritas para pixels de valor 5 , exceto os de categoria Áreas Urbanas/Áreas Antropizadas

O modelo que será apresentado aqui é um pouco mais complexo do que os demonstrados até o momento, pois além de estabelecer áreas restritas, excluindo de tal regra as Áreas Urbanas/Áreas Antrópicas, ainda estabelece diferentes pesos para cada aspecto socioambiental considerado. A seguir, segue a Tabela $12 \mathrm{com}$ os aspectos socioambientais restritivos considerados e os pesos adotados para cada um deles. 
Tabela 12: Pesos atribuídos as restrições socioambientais legais. Fonte: própria.

\begin{tabular}{|l|c|}
\hline Aspecto/Restrição Socioambiental Legal & Peso \\
\hline Mata Atlântica+Áreas Urbanas/Antropizadas & 15 \\
\hline Terras Indígenas & 10 \\
\hline Zona de Amortecimento de Terras Indígenas & 9 \\
\hline Comunidades Quilombolas & 10 \\
\hline $\begin{array}{l}\text { Zona de Amortecimento de Comunidades } \\
\text { Quilombolas }\end{array}$ & 9 \\
\hline Cavidade Naturais & 10 \\
\hline Potencial Espeleológico & 9 \\
\hline Áreas Prioritárias para Conservação da Biodiversidade & 9 \\
\hline Unidades de Conservação & 10 \\
\hline Zona de Amortecimento de Unidades de Conservação & 9 \\
\hline
\end{tabular}

A vantagem desse modelo é a possibilidade de se conjugar as restrições e a importância de cada aspecto socioambiental, dando à análise mais instrumentos para que se chegue mais próximo da realidade. Como resultado, segue o zoneamento realizado, através do mapa observado na Figura 35 adiante.

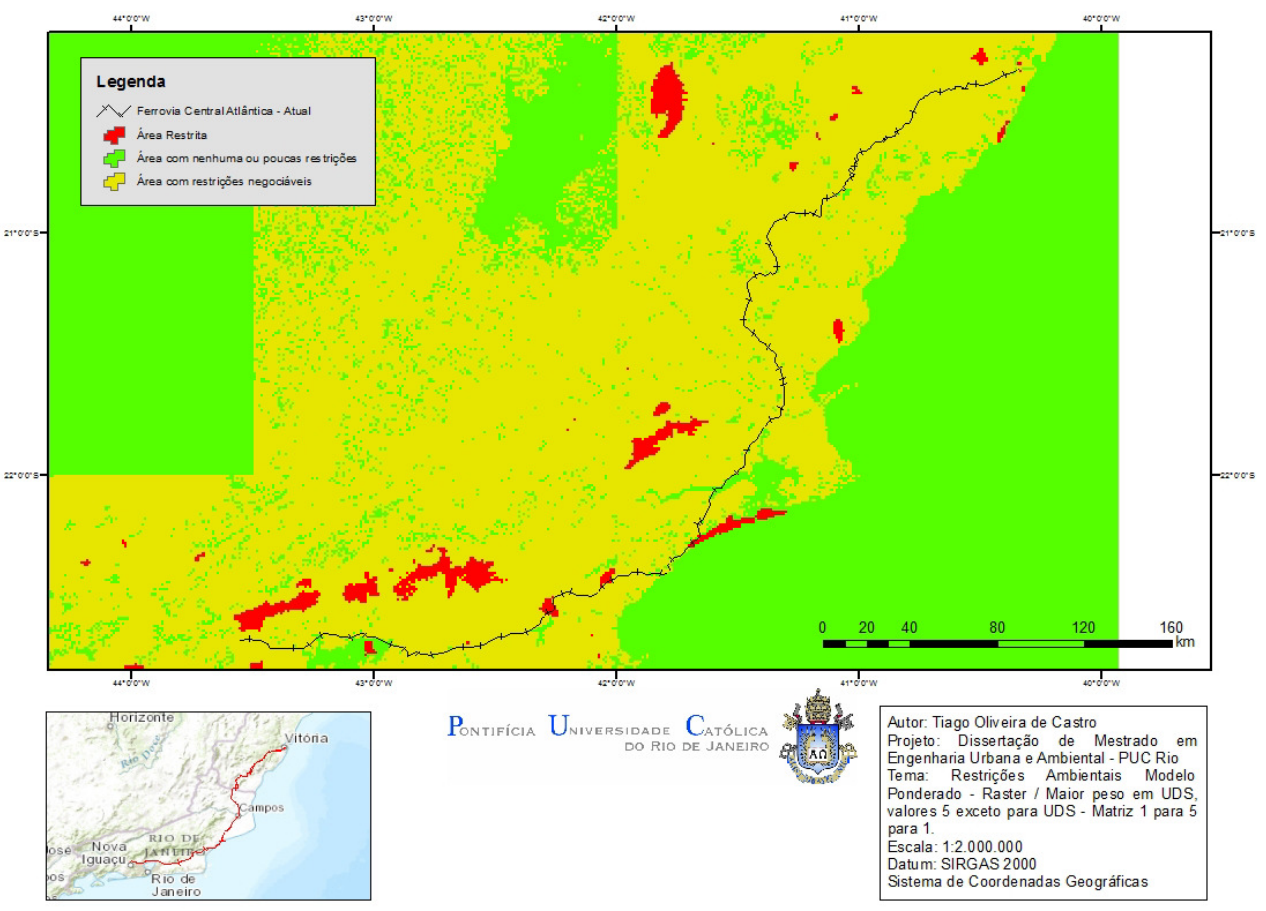

Figura 35: Mapa do Modelo "Média Ponderada" com atribuição de pesos diferenciados para as restrições socioambientais legais e adoção de áreas restritas para pixels de valor 5, exceto os de categoria Áreas Urbanas/Áreas Antropizadas. Fonte: própria. 


\subsection{Definição do traçado ferroviário - Análise comparativa}

Após a apreciação do resultado do modelo, parece que ao considerar uma maior complexidade na sua construção, o zoneamento torna-se bastante limitador para atuação no que tange ao uso e ocupação do solo, apontando para a necessidade de maiores ajustes na ponderação.

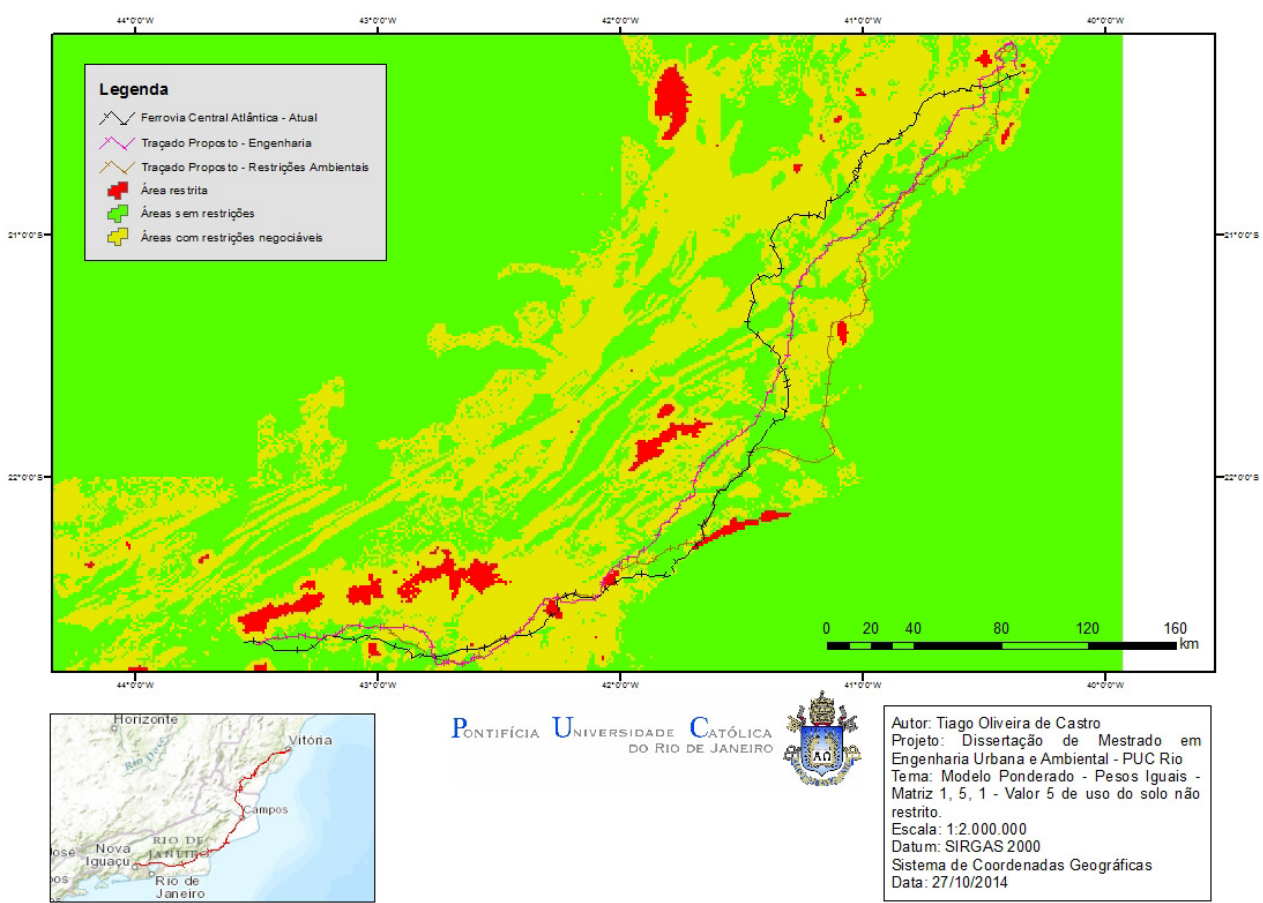

Figura 36: Mapa do Modelo "Média Ponderada" com atribuição equalitária de pesos e adoção de áreas restritas para pixels de valor 5, exceto os de categoria Áreas Urbanas/Áreas Antropizadas, contendo o traçado da EF-118 e suas alternativas. Fonte: própria.

Para o Estudo de Viabilidade Técnica, Econômica e Ambiental do traçado da ferrovia definiu-se como o modelo mais adequado, portanto, o "Média Ponderada com atribuição equalitária de pesos e adoção de áreas restritas para pixels de valor 5, exceto os de categoria Áreas Urbanas/Áreas Antropizadas". Esse modelo foi encaminhado à uma equipe de projetistas de engenharia, que por sua vez realizou ajustes ao traçado projetado a princípio, sem ter levado em conta a variável socioambiental legal de restrições ao uso do solo. O mapa que pode ser observado na figura 36 acima apresenta o modelo definido como o mais adequado, o zoneamento de restriçòes socioambientais legais e os traçados ferroviários, a saber: ferrovia existente, projeto considerando apenas aspectos de 
viabilidade de engenharia e projeto considerando a viabilidade socioambiental legal e de engenharia.

Para termos de comparação, o traçado original existente hoje, possui extensão de aproximadamente $640 \mathrm{~km}$, já o traçado proposto considerando somente critérios de engenharia possui extensão de aproximadamente $620 \mathrm{~km} \mathrm{e}$ por fim, o traçado proposto após a aplicação do modelo definido como o mais adequado, a saber: dados raster de "Média Ponderada com atribuição equalitária de pesos e adoção de áreas restritas para pixels de valor 5, exceto os de categoria Áreas Urbanas/Áreas Antropizadas" possui uma extensão aproximada de 670km. A Figura 37 ilustra os três traçados citados.

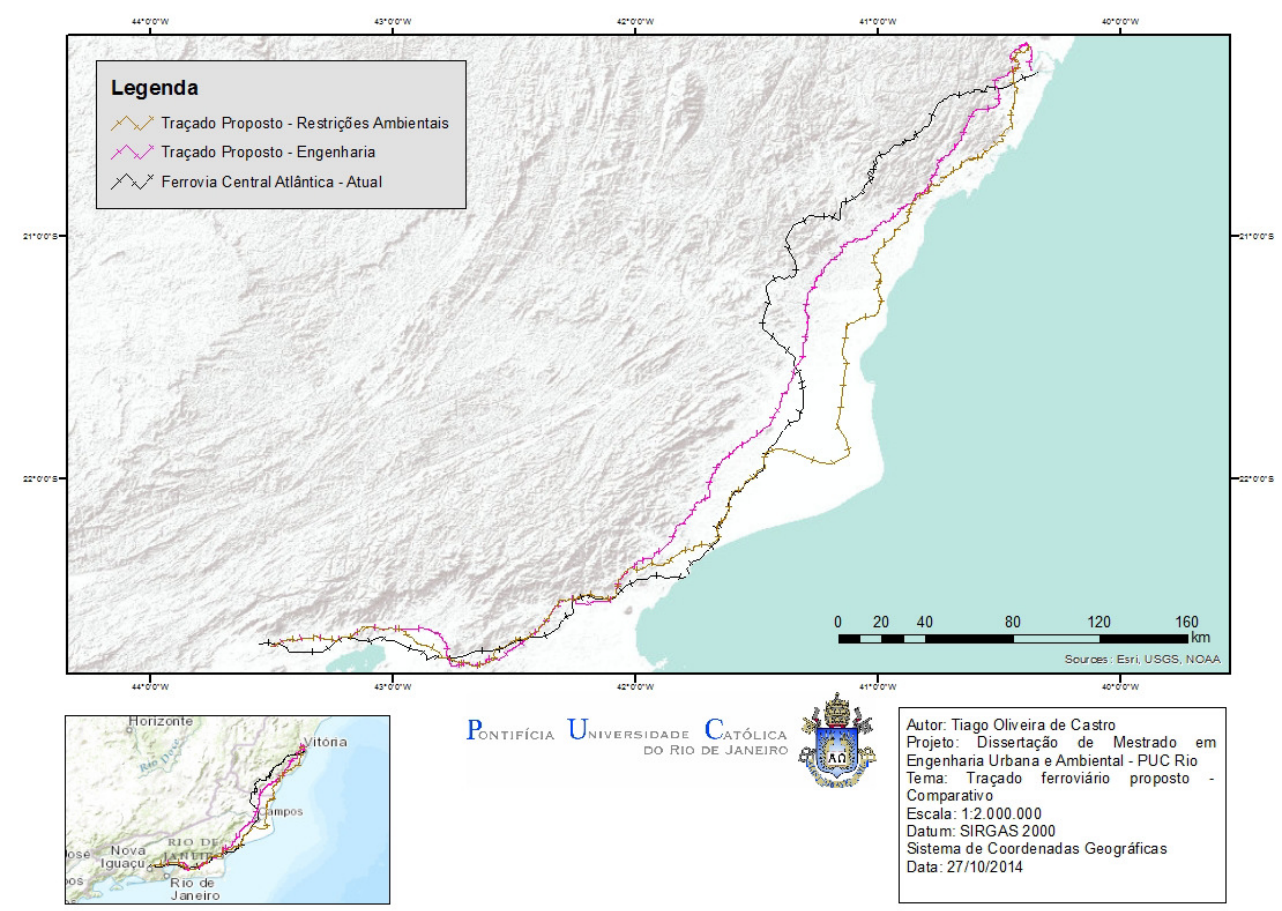

Figura 37: Mapa do traçado da EF-118 e suas alternativas propostas. Fonte: própria.

O traçado considerando restrições socioambientais legais é assim o mais extenso, porém é o que apresenta menor chance de encontrar alguma limitação ao projeto. Dessa maneira, o empreendedor tem condições de avaliar o que será mais vantajoso para a obra pretendida. 
Adiante, seguem os mapas que representam o traçado atual, o traçado que considerou aspectos de engenharia e o traçado que considerou aspectos de restrições socioambientais legais repectivamente, nas Figuras 38, 39 e 40 respectivamente.

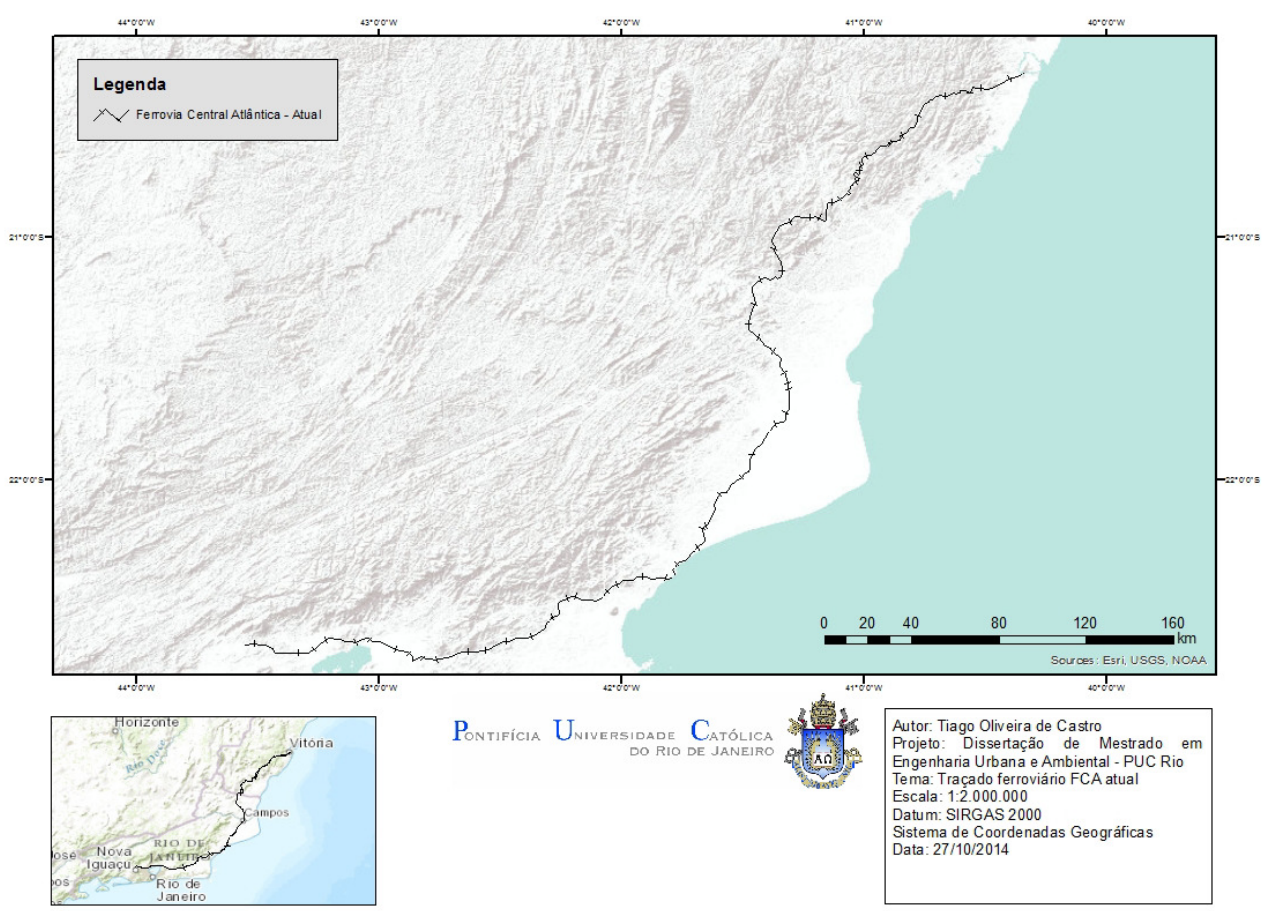

Figura 38: Mapa do traçado da EF-118. Fonte: própria. 


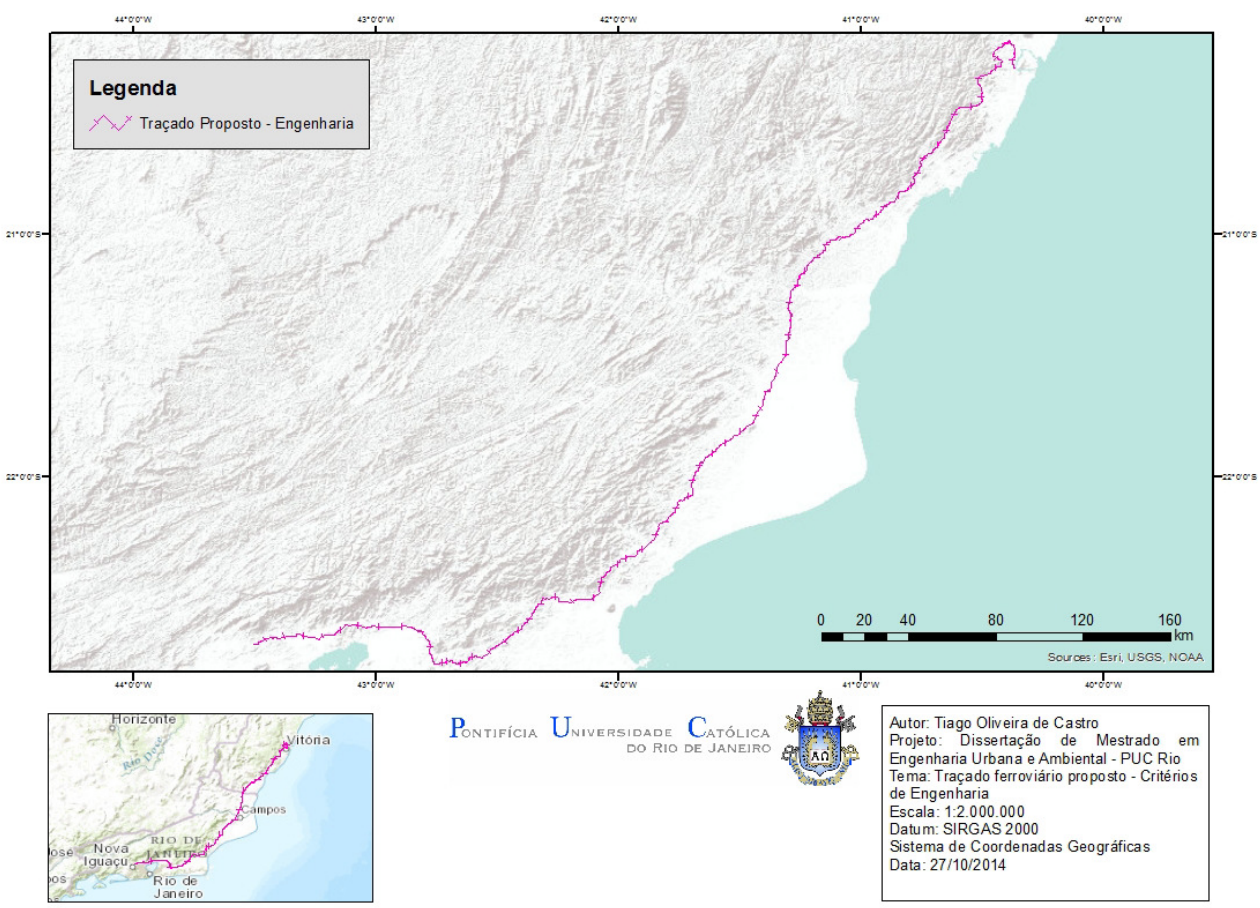

Figura 39: Mapa de proposta alternativa de traçado para EF-118, considerando aspectos de engenharia. Fonte: própria.

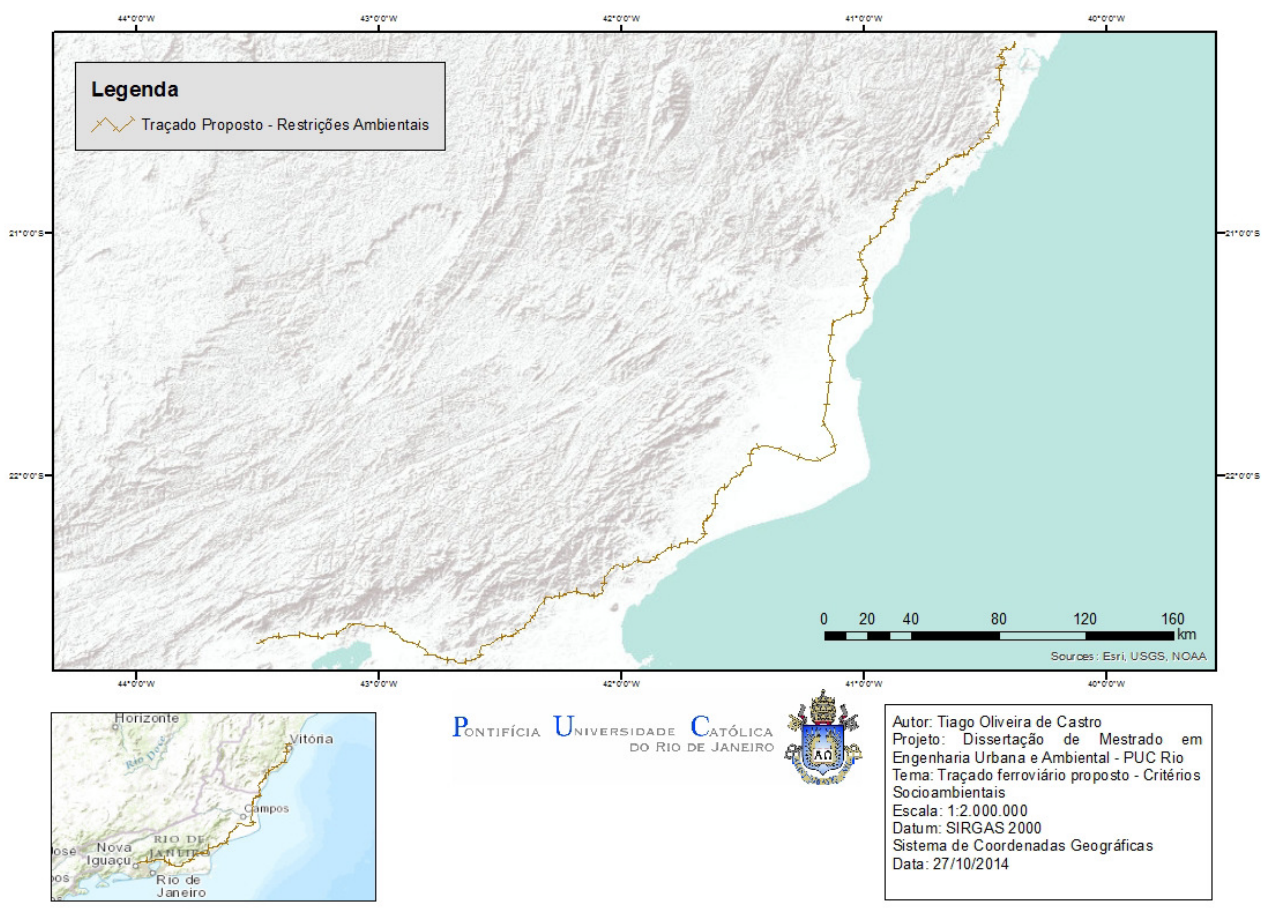

Figura 40: Mapa de proposta alternativa de traçado para EF-118, considerando aspectos de engenharia e do modelo de zoneamento socioambiental de restrições legais elaborado no presente estudo. Fonte: própria. 


\section{Conclusão}

O trabalho aqui desenvolvido se propôs a oferecer uma metodologia de construção de modelos ambientais alicerçado em dados espaciais. Para isso, foi elaborada uma base de dados a partir de material disponibilizado em órgãos ambientais oficiais e a partir da mesma, a elaboração de modelos geoespaciais.

Elaborar um zoneamento e traduzi-lo em mapa é uma tarefa reconhecidamente fundamental para uma boa gestão do território. Sua importância se faz presente tanto para o poder público, que pode utilizar esse produto no planejamento e promoção de políticas públicas com foco em mediação de conflitos de uso e ocupação do solo, quanto por empreendedores interessados em executar obras, principalmente as de infraestrutura, com maior segurança jurídica.

Para o caso apresentado, isso fica evidente, uma vez que a legislação ambiental brasileira, como discutido anteriormente, é uma das mais avançadas do mundo, no que concerne a preservação e conservação socioambiental. Entretanto, os dados espaciais socioambientais disponibilizados em bases públicas admnistrados por órgãos oficiais muitas vezes estão segregados e são pouco divulgados.

Assim, para etapas preliminares de planejamento, principalmente na de escolhas de alternativas locacionais, sugere-se utilizar o zoneamento como uma ferramenta estratégica, jogando luz sobre o terreno ao qual se pretende interagir e alterar. Dessa forma o empreendedor é capaz de tatear o espaço, sem necessariamente realizar trabalhos de campo ou levantamentos primários onerosos. Isso não descarta a necessidade de se conhecer com maiores detalhes e acurácia o ambiente, na medida em que os estudos de viabilidade entram em etapas mais avançadas, exigidas no licenciamento ambiental. 
Durante a construção da base de dados utilizada no zoneamento apresentado, notou-se que muitos dos dados espaciais careciam de informações essenciais, tais como: indicação de suas fontes, data de execução do mapeamento, métodos utilizados para a restituição vetorial ou de interpretação de imagens de satélite na classificação do uso e cobertura do solo, escala de levantamento, dentre outras lacunas que podem comprometer a execução de um trabalho e seus resultados. Em suma, sem segurança e rastreabilidade de informações básicas, toda a cadeia de construção de um zoneamento pode não representar fielmente a realidade.

Os zoneamentos aqui desenvolvidos buscaram apresentar alternativas técnicas adequadas para uso no planejamento de empreendimentos. O que se viu foi que os resultados e análises realizados dependem fortemente dos dados de entrada e também da maneira como são processados. Não se pretendeu aqui apresentar o melhor método para a identificação de principais restrições socioambientais legais, mas debater alguns métodos e modelos, bem como identificar qual deles se encaixa melhor na realidade conhecida.

No caso da definição do melhor traçado para a nova ferrovia a ser desenvolvida entre a cidade de Nova Iguaçu no Rio de Janeiro e Cariacica no Espírito Santo, mostrou-se o modelo mais adequado aquele chamado "Média Ponderada com atribuição equalitária de pesos e adoção de áreas restritas para pixels de valor 5, exceto os de categoria Áreas Urbanas/Áreas Antropizadas". Esse modelo foi apresentado atavés do zoneamento de restrições socioambientais legais para a equipe de projeto de engenharia, que decidiu alterar o traçado anterior, que não levava em conta a variável socioambiental legal.

Os demais modelos desenvolvidos e testados apresentaram resultados que não se mostraram condizentes com a realidade conhecida. Ou mostraram-se extremamente restritivos ou extremamente permissivos quanto às atividades que poderiam ser desenvolvidas ao longo do trecho estudado.

Ademais, o uso de dados vetoriais não se mostrou eficaz para elaboração de modelos, devido às limitações quanto ao estabelecimento de pesos para as 
variáveis escolhidas na análise espacial e a dificuldade de manipulá-los. Assim, por oferecerem um leque limitado de opções para interpretação dos fenômenos apresentados no espaço, recomenda-se que não sejam utilizados, ao menos em trabalhos similares ao presente estudo.

Desta maneira, é interessante salientar que, por limitações dos próprios órgãos públicos em fornecer dados inteiramente confiáveis, não foram considerados aspectos que podem subsidiar o modelo adotado, tornando-o ainda mais preciso. Dados como hidrografia, curvas de nível, modelos digitais do terreno para identificação de declividades acentuadas e assentamentos rurais, por exemplo, não compuseram a análise realizada. Entretanto, nada impede que ao modelo utilizado, tais dados sejam adicionados na análise espacial para etapa de estudos preliminares como os de viabilidade técnico, econômica e ambiental. Também, o resultado do zoneamento pode ser parte integrante de estudos mais detalhados sendo usado como dado de entrada com a finalidade de compor um quadro mais amplo da realidade socioambiental, que é o real objetivo de todo planejamento que se pretende ambientalmente sustentável.

Por fim, a contribuição do trabalho aqui desenvolvido, foi elaborar modelos de análise espacial utilizando dados públicos, que pudessem traduzir, dentro das limitações já citadas anteriormente, a legislação ambiental brasileira e como a mesma se manifesta no espaço, o que fica mais didático e evidente através do uso de mapas. Sendo assim, pesquisadores, estudantes e empreendedores podem se cercar de informações claras e úteis tanto na gestão do território, quanto na tomada de decisão. 


\section{Referências Bibliográficas}

AHLQVIST, O. 2009. Overlay (in GIS). In The International Encyclopedia of Human Geography. Edited by Kitchin, R. and Thrift N. Oxford, UK: Elsevier. 4855.

ALEMANHA. Spatial Development and Spatial Planning in Germany. Bonn: Federal Office for Building and Regional Planning, 2001. 73 p.

ALMEIDA, Josimar Ribeiro de. (coord.), ORSOLON, Anan Maria; MALHEIROS, Telma Marques; PEREIRA, Sonia Regina de Brito; AMARAL, Franciso, SILVA, Dalton Marcondes. Planejamento Ambiental: caminho para participação popular e gestão ambiental para nosso futuro comum; uma necessidade, um desafio. Rio de Janeiro: Thex Ed.; Biblioteca Estácio de Sá, 176 p. 1993.

ANSELIN, L. (1999) SpaceStat Tutorial, 1992. Disponível em $<$ http://www.spacestat.com> Acesso em 06 de julho de 2014.

ARONOFF, S. Geographic information systems: a management perspective. Ottawa: DL Publications, 1989. 249p.

BALLESTER, M.R.V; SANTOS, J.E.; FERESIN, E.G.; OBARA, A.A.; KRUSCHE, A.V.; BARROSO, G.F.; ALBUQUERQUE, A.L.S.; PIRES, J.S.R.; MOZETO, A.A.; CAVALHEIRO, F.; MARGARIDO, L.A.C.; GENTIL, J.G. Desenvolvimento planejado (utilização do solo) da estação ecológica de Jataí. In: ESTEVES, F.A. (ed.). Oecologia Brasiliensis. v.1, Rio de Janeiro: UFRJ, 616 p., p. 511-522. 1995.

BARRETO, Margarita. Planejamento e organização em turismo. 5 ed., Campinas: Papirus, 101 p. 2000. (Coleção Turismo). 
BRAGA, B.; HESPANHOL, I., CONEJO, J.G.L., MIERZWA, J.C., BARROS, M.T.L, SPENCER, M., PORTO, M., NUCCI, N., JULIANO, N., EIGER, S. 2005. Introdução à engenharia Ambiental. O desafio do desenvolvimento sustentável. São Paulo: Pearson Prentice Hall (ed), 2005. 318p.

BECKER, B. K. \& Egler, C.A.G. 1997. Detalhamento da Metodologia para a Execução do Zoneamento Ecológico-Econômico pelos Estados da Amazônia Legal. Brasília: MMA/SAE.

BERTINI, G. C. (2003b) Uma modelagem orientada a objeto para o mapa urbano básico de Belo Horizonte (MUB/BH), Monografia de Especialização, Pontifica Universidade Católica de Minas Gerais.

BERTINI, G. C. (2003c) Uma modelagem orientada a objeto para o mapa urbano básico de Belo Horizonte (MUB/BH), Monografia de Especialização, Pontifica Universidade Católica de Minas Gerais.

BLOWERS, Andrew, (ed.). Planning for a sustainable environment; a report by the tow and country planning association. Londres: TCPA/Earthscan publications ltda, 241 p., 1996.

BRASIL. Agência Nacional de Transportes Terrestres, ESTUDO AMBIENTAL - FERROVIA: Açailândia/MA - Vila do Conde/PA, 31p., 2013.

BRASIL. Ministérios das Minas e Energia. Secretaria Geral. Proposta Metodológica para Estudos Integrados do Potencial Geoambiental em Escalas de Semidetalhe. s.l., (Projeto Radambrasil - Grupo de Estudos Integrados, coordenado por Teresa Cardoso da Silva), 16 p., 1984.

CADAVID GARCIA, E. A. Zoneamento agroecológico e sócio-econômico da Bacia Hidrográfica Brasileira do rio Paraguai: uma abordagem numérica preliminar (documento para discussão). Corumbá: Embrapa - CPAP, 65 p., 1991. 
CÂMARA, G. As Roupas Novas do GIS (Parte II). Revista InfoGEO, Ano 3, No 13, Maio/Junho. 2000.

CÂMARA, G.; MONTEIRO, A M.V.; CARVALHO, M. S.; DRUCK, S (2002) Análise Espacial de dados Geográficos, 2a edição (online), disponível http://www.dpi.inpe.br/gilberto/livro/analise/, capturado 10/2014.

CHAGAS, César da Silva; CARVALHO JÚNIOR, Waldir de; PEREIRA, Nilson Rendeiro; BHERING, Sílvio Barge; STEINMETZ, Sílvio. Um métododo para elaboração de zoneamentos agropedoclimáticos: estudo de caso do arroz irrigado no Rio Grande do Sul. Revista Brasileira de Agrometeorologia, v.9, n.3 (número especial: Zoneamento Agrícola), p.571-580, 2001.

CHRISTOFOLETTI, Antonio. Modelagem de sistemas ambientais. São Paulo: Edgard Blücher Ltda, 236 p., 1999.

COELHO, André Luiz Nascentes. 2007. Aplicações de Geoprocessamento em

Bacias de Médio e Grande Porte. Anais XIII Simpósio Brasileiro de Sensoriamento Remoto, Florianópolis, Brasil, INPE, p. 2437-2445.

CONYERS, Diana; HILLS, Peter. An introduction to development planning in the third world. Fort Willian, Scotland: John Wiley \& Sons, 271 p., (Public Administration in Developing Countries), 1984.

CREPANI, E. et al. Curso de Sensoriamento Remoto Aplicado ao Zoneamento Ecológico- Econômico. São José dos Campos - SP: INPE, 1996.

CREPANI, E. et al. Sensoriamento Remoto e Geoprocessamento Aplicados ao Zoneamento Ecológico-Econômico e ao Ordenamento Territorial. São José dos Campos - SP: INPE, 2001.

CUTTER, S. L.; MITCHELL, J. T. and SCOTT, M. S. Handbook for conducting a GIS-BASED Hazads Assessment at the county level. Departament of Geography, University of South Carolina. 1997. 
DEL PRETTE, M. E.; MATTEO, K. C. Origens e possibilidades do Zoneamento Ecológico- Econômico no Brasil. In: Ministério do Meio Ambiente. Caderno de Referência: subsídios ao debate. Brasília: MMA/SDS, 2006.

DORNEY, Robert.S. The professional practice of environmental management. New York: Spring-Verlag, Lindsay C. Dorney, ed., 228 p., 1989.

ESRI, ArcGIS Resources. Disponível em: < http://resources.arcgis.com/en/home/> Acesso em 11 de agosto de 2014.

FAZAL, S. GIS BASICS. New Age International Limited Publishers. New Delhi. 2008.

FRANCO, Maria de Assunção Ribeiro. 2 ed., Planejamento Ambiental Para a Cidade Sustentável. São Paulo: AnnaBlume/FAPESP, 296 p., 2001.

GANDRA, T. B. R. Elementos geomorfológicos e socioambientais como subsídios para a elaboração do Zoneamento Ecológico-Econômico Costeiro ZEEC. 2008. 85 p. Dissertação (Mestrado) - Universidade Federal do Rio Grande do Sul, Rio Grande, 2008.

GARCÍA-HUIDOBRO V., Raimundo. Zonas agrícolas degradadas en una economía globalizada. In: Programa Cooperativo para el Desarollo Tecnológico Agropecuario del Cono Sur. Recuperación y manejo de ecossistemas degradados. Dialogo XLIX. Montevideo: IICA/PROCISUR . Montevideo: IICA/PROCISUR, 112 p., p. 81-84, 1998.

GOLDENSTEIN, M.; ALVES, M. F.; AZEVEDO, R. L. S. “A Indústria de Implementos Rodoviários e Sua Importância para o Aumento da Eficiência do Transporte de Cargas no Brasil”. BNDES Setorial, n. 24, set. 2006.

GRIFFITH, C. Zoneamento: uma análise crítica. Ambiente, São Paulo, v.3, n.3, p.20-25, 1989. 
JOYCE, F. E., WILLIAMS, M. E., JOHNSON, D. M.,(1975) The Environmental Effects of Urban Road Traffic - Evaluating Alternative Engineering and Control, Vol. 16, no4, April, 1975.

LIMA, A. Zoneamento Ecológico-Econômico à luz dos direitos socioambientais. Curitiba: Juruá, 2006. 288 p.

MAZUR, F. P. R., Mapeamento da susceptibilidade a movimentos de massa através de assinaturas ambientais no Maciço da Tijuca, Rio de Janeiro (2013). Dissertação (Mestrado) - Pontifícia Universidade Católica do Rio de Janeiro, Departamento de Engenharia Civil. 2013.

MELLO, J. F. F., Interpretação e Análise de SIG dos Movimentos de Massa Ocorridos no Maciço da Tijuca (2010), Munícipio do Rio de Janeiro, Utilizando Imagens de Satélite da Alta Definição. Dissertação (Mestrado) Pontifícia Universidade Católica do Rio de Janeiro, Departamento de Geografia. 2011.

MENESES, H. B. Interface Lógica em Ambiente SIG para Bases de Dados de Sistemas Centralizados de Controle do Tráfego Urbano em Tempo Real, Dissertação de Mestrado, Centro de Tecnologia, Universidade Federal do Ceará, Fortaleza. 2003.

MENESES, H. B. Interface Lógica em Ambiente SIG para Bases de Dados de Sistemas Centralizados de Controle do Tráfego Urbano em Tempo Real, Dissertação de Mestrado, Centro de Tecnologia, Universidade Federal do Ceará, Fortaleza. 2003.

MILLIKAN, B.; DEL PRETTE, M. E. Seminário: Avaliação da metodologia do Zoneamento Ecológico-Econômico para a Amazônia Legal (Documento base para discussão). Manaus: Ministério do Meio Ambiente, 2000. 
MINISTÉRIO DE DESENVOLVIMENTO, INDÚSTRIA E COMÉRCIO EXTERIOR, Programa de Investimento em Logística. Disponível em $<$ http://www.logisticabrasil.gov.br/> Acesso em 23 de agosto de 2014.

MITCHEL, A. The ESRI guide to GIS analysis. Redlands: ESRI, 1999.

MONTAÑO, M. et al. A necessidade de incorporação do zoneamento ambiental como instrumento de planejamento e gestão territorial urbana. In: International Congress on Environmental Planning and Management, 2005, Brasília. Proceedings... Brasília: Universidade Católica de Brasília, 2005. p. 1 22.

MOURA, A. C. M. 2007. Reflexões metodológicas como subsídios para estudos ambientais baseados em Análise de Multicritérios. Departamento de Cartografia. Univiversidade Federal de Minas Gerais. Anais XIII Simpósio Brasileiro de Sensoriamento Remoto, Florianópolis, Brasil, INPE, pp. 2899-2906

NEGREIROS, I. P. M. 2003. Processamento de dados topográficos para o mapeamento da curvatura de vertentes. Dissertação de Mestrado - Instituto Agronômico de Campinas, 104p.

OLIVEIRA, M. P. G. Sistema Espacial de Apoio à Decisão: Modelos para análise do adensamento de atividades econômicas no espaço urbano. Dissertação de Mestrado, Escola de Governo de Minas Gerais da Fundação João Pinheiro. 1997.

OREA, Domingo Gómez. Evaluacion de Impacto Ambiental. 2 ed., Madrid: Editorial Agrícola Española, 259 p., 1994.

PARTIDÁRIO, M. R., 1999, Strategic Environmental Assessment - principles and potential, ch 4 , in Petts, Judith (Ed.), Handbook on Environmental Impact Assessment, Blackwell, London: 60-73. 
PEREIRA, F. L. CAMPOS V.B.G.(2004), Uma aplicação de SIG para Análise Espacial da Poluição Atmosférica num Trecho Rodoviário. Relatório p/Grupo SEAD-T do Fundo Setorial em Transporte,CNPq

PIVELlO, V. R.; BITENCOURT, M. D.; MANTOVANI, W.; MESQUITA JÚNIOR, H. N. De; BATALHA, M. A.; SHIDA, C. N. Proposta de zoneamento ecológico para a reserva de cerrado Pé-de-Gigante (Santa Rita do Passa Quatro, SP). Brazilian Journal of Ecology, Rio Claro, ano2, n.2, p.108-118, 1998.

RAIA, A. A. J., (2000) Acessibilidade e Mobilidade na estimativa de um índice de potencial de viagens utilizando Redes Neurais Artificiais, Tese de Doutorado, Universidade de São Paulo, São Paulo.

RANIERI, V. E. L. et al. O zoneamento ambiental como instrumento de política e gestão ambiental. In: Evaldo Luiz Gaeta Espíndola; Edson Wendland. (Org.). PPG-SEA: Trajetórias e perspectivas de um curso multidisciplinar. São Carlos: Rima, 2005. v.4, p. 109-136.

RANIERI, Vítor Eduardo Lima. Discussão das potencialidades e restrições do meio como subsídio para o zoneamento ambiental: o caso do município de Descalvado (SP). 87 p. Dissertação (Mestrado em Engenharia Hidráulica) Escola de Engenharia de São Carlos, Universidade de São Paulo, São Carlos, 2000.

REVISTA DO BNDES, RIO DE JANEIRO, V. 14, N. 29, P. 35-60, JUN. 2008. ROCHA, M. M. (2004) Modelagem da Dispersão de Vetores Biológicos com emprego da Estatística Espacial, Dissertação de Mestrado, Instituto Militar de Engenharia-IME, Rio de Janeiro.

REVISTA LOGÍSTICA, O Transporte de cargas. Disponível em: $<$ http://www.imam.com.br/logistica/artigos/serie-transporte-de-cargas/1525-o-

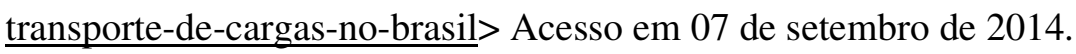


ROCHA, M. M. Modelagem da Dispersão de Vetores Biológicos com emprego da Estatística Espacial, Dissertação de Mestrado, Instituto Militar de Engenharia-IME, Rio de Janeiro. 2004.

RODRIGUES, M. Geoprocessamento: Um retrato atual. In: Revista Fator GIS, Ano 1, no2. Curitiba. 1993.

ROGERSON, P.A.; FOTHERINGHAM, A.S. 1994. 'GIS and spatial analysis: Introduction and overview'. In Spatial Analysis and GIS, edited by Fotheringham, A.S.; Rogerson, P.A. London: Taylor and Francis. 1-10.

ROSS, J. L. S. Ecogeografia do Brasil: subsídios para o planejamento ambiental. São Paulo: Oficina de textos, 2006.

ROSSETI, Luiz Antônio. Zoneamento agrícola em aplicações de crédito e securidade rural no Brasil: aspectos atuariais e de política agrícola. Revista Brasileira de Agrometeorologia, v.9, n.3 (número especial: Zoneamento Agrícola), p. 386-399, 2001.

SANTOS, R. F. Planejamento Ambiental - teoria e prática. São Paulo: Oficina de textos, 2004. 184 p.

SCHOLL, B.; ELGENDY, H.; NOLLERT, M. Spatial Planning in Germany: formal structure and future tasks. Instituto de planejamento urbano e espacial da Universidade de Karlsruhe. Karlsruhe: Karlsruhe University Press, 2007. 73 p.

SCHROEDER, E. M.; CASTRO, J. C. “Transporte Rodoviário de Carga: Situação Atual e Perspectivas”. Revista do BNDES, n. 6, dez. 1996.

SILVA, A. B. Sistema de Informações Geo-referenciadas: conceitos e fundamentos. Campinas, SP: Editora da Unicamp, 1999, 235p.

SILVA, A. B., BRITES, R. S., SOUZA A. R Caracterização do Meio Físico da Microbacia Quatro Bocas, em Angelim, PE, E Sua Quantificação Por 
Sistema De Informação Geográfica, Pesq. agropec. bras., Brasília, v.34, n.1, p.109-117, jan. 1999.

SILVA, J. S. V.; SANTOS, R. F. Zoneamento para planejamento ambiental: vantagens e restrições de métodos e técnicas. Cadernos de Ciência e Tecnologia, v. 21, n. 2, p. 221-263, mai./ago., 2004.

SMITH, L. Graham. Impact Assessment and Sustainable Resource Management. New York: Longman Scientific Technical and John Wiley \& Sons, 209 p., 1993.

SOUZA, M. P. As bases legais e os zoneamentos ambientais. In: $2^{\circ}$ Simpósio de Geotecnologias no Pantanal, 2009, Corumbá. Anais eletrônicos... Campinas: Embrapa Informática Agropecuária; São José dos Campos: INPE. Disponível em: $<$ http://mtc-m17.sid.inpe.br/col/sid.inpe.br/mtc m17@80/2006/12.12.16.59/doc/p151.pdf >. Acesso em: 15 out. 2014.

SOUZA, W. de. Planejamento da rede viária e zoneamento em unidades de conservação, empregando um sistema de informações geográficas. 89 p. Dissertação (Mestrado em planejamento) - Universidade Federal de Viçosa, Viçosa, 1990.

STOCKER, L. \& BURKE, G. (2006). Overlay mapping - A methodology for place-based sustainability education. Chapter 25 in S. Wooltorton \& D. Marinova (eds), Sharing wisdom for our future: Environmental education in action. Sydney: Australian Association for Environmental Education.

STRAUCH, J. C. M.; SOUZA, J. M.; MATTOSO, M. L. de Q.; Estudo dos modelos de dados dos Sistemas de Informação Geográfica ARC/INFO e SPRING. Programa de Engenharia de Sistemas e Computação, COPPE/ UFRJ, 1998.

VAN DE LAAK, P.J.A. A framework for sustainable regional planning. In: VAN LIER, H. N.; JAARSMA, C. F.; JURGENS, C. R.; BUCK, A. J. (eds.). 
Sustainable land use planning. Proceedings of a International Workshop, 2-4 September 1992, Wageningen, The Netherlands. Wageningen: Elsevier Science B. V., 360 p., (chapter 24 - p.303-314), 1994.

VAN LIER, H.N. Land use planning in perspective of sustainability: an introduction. In: VAN LIER, H. N.; JAARSMA, C. F.; JURGENS, C. R.; BUCK, A. J. (eds.). Sustainable land use planning. Proceedings of a International Workshop, 2-4 September 1992, Wageningen, The Netherlands. Wageningen: Elsevier Science B. V., 360 p., (chapter 1 - p.1-9), 1994.

WANKE, PETER; FLEURY, PAULO FERNANDO. Transporte de cargas no Brasil: Estudo exploratório das principais variáveis relacionadas aos diferentes modais e às suas estruturas de custos. (2006). Disponível em: $<$ http://www.ipea.gov.br/sites/000/2/livros/estruturadinamica/capitulo\%2012_tran sportes.pdf > Acesso em: 15 out. 2014.

WESTMAN, Walter E. Ecology, impact assessment, and environmental planning. New York: John Wiley \& Sons Inc., 532 p., (cap.1, p.1-26), 1985.

ZAIDAN, R. T., XAVIER DA SILVA, J., Geoprocessamento \& Análise Ambiental. 2 ed. Rio de Janeiro, Bertrand Brasil, 2007. 